\title{
The Incorporation of Aluminum Hydroxide in Water Based Muds to Stabilize Marcellus Shale Drilling in West Virginia
}

Hussain Ali Al-Fadhel

West Virginia University

Follow this and additional works at: https://researchrepository.wvu.edu/etd

\section{Recommended Citation}

Al-Fadhel, Hussain Ali, "The Incorporation of Aluminum Hydroxide in Water Based Muds to Stabilize Marcellus Shale Drilling in West Virginia" (2012). Graduate Theses, Dissertations, and Problem Reports. 3356.

https://researchrepository.wvu.edu/etd/3356

This Thesis is protected by copyright and/or related rights. It has been brought to you by the The Research Repository @ WVU with permission from the rights-holder(s). You are free to use this Thesis in any way that is permitted by the copyright and related rights legislation that applies to your use. For other uses you must obtain permission from the rights-holder(s) directly, unless additional rights are indicated by a Creative Commons license in the record and/ or on the work itself. This Thesis has been accepted for inclusion in WVU Graduate Theses, Dissertations, and Problem Reports collection by an authorized administrator of The Research Repository @ WVU. For more information, please contact researchrepository@mail.wvu.edu. 


\title{
The Incorporation of Aluminum Hydroxide in Water Based Muds to Stabilize Marcellus Shale Drilling in West Virginia
}

\author{
Hussain Ali Al-Fadhel
}

Thesis submitted to the College of Human Resources and Education at West Virginia University in partial fulfillment of the requirements for the degree of Master of Science in Petroleum and Natural Gas Engineering

Daniel E. Della-Giustina, Ph.D.

Ilkin Bilgesu, Ph.D.

Samuel Ameri, M.S,Chair.

Department of Petroleum and Natural Gas Engineering

Morgantown, West Virginia

2012

Keywords: Marcellus Shale; Inhibition; Mud additives; Swelling; Aluminum Hydroxide; Drilling Fluids; Mud; precipitation chemistry; Pore pressure transmission 


\section{Abstract: \\ Thesis submitted to the College of Human Resources and Education at West Virginia University in partial fulfillment of the requirements for the degree of Master of Science in Petroleum and Natural Gas Engineering}

\section{Hussain Ali Al-Fadhel}

The purpose of this study was to develop a safe and environmentally acceptable water base mud that will be able to suppress swelling and promote stability to the West Virginian Marcellus shale. The problem was approached by utilizing aluminum precipitation chemistry in the drilling fluid, unlike the traditional cation-exchange approach.

A dynamic swelling meter was designed by modifying a $0.001 \mathrm{~mm}$ resolution dial indicator and using a specially programmed smart cable connecting the dial indicator to a computer. The swelling data was acquired by the smart cable every six seconds. As a result, there were 14,400 measured points for each sample for the 24 hours test duration.

The Marcellus shale samples were prepared by cutting a core sample taken from a depth of 6,025 $\mathrm{ft}$ by a rotary saw. The original core sample was cylindrical with a diameter of 2 -in. and a height of about 20-in. It was cut into smaller sections with the same diameter and a height ranging from $\{2.5$ to 7$\} \mathrm{mm}$. The samples were dried in an oven at $70^{\circ} \mathrm{C}$ until weight was stabilized. The average moisture content of the samples was approximately $1 \%$.

Mud samples were prepared with Aquagel (natural clay), Soda Ash (Sodium carbonate), potassium alum (potassium double sulfate of aluminum), and Cellex polymer (Carboxymethyl cellulose sodium). All the substances used in developing the mud are biodegradable and were EC50 (half maximal effective concentration) tested. The base mud design had $10 \mathrm{lb} / \mathrm{bbl}$ Aquagel, $2 \mathrm{lb} / \mathrm{bbl}$ Cellex, and $5 \mathrm{lb} / \mathrm{bbl}$ Soda Ash. Later the potassium alum was added to the base mud with different concentrations $(0.5,1,0.6$, and 0.7$) \mathrm{lb} / \mathrm{bbl}$ for a sensitivity test.

Each water/mud sample was tested on three shale specimens to confirm the results. Swelling test was first conducted with fresh water, which yielded the highest swelling percentage in an average of 5\%. The base mud resulted with approximately $3 \%$ swelling and $1.41 \%$ swelling was observed with the $0.5 \mathrm{lb} / \mathrm{bbl}$ potassium alum. Also, $1.24 \%$ swelling with the $0.6 \mathrm{lb} / \mathrm{bbl}$ potassium alum, and no swelling with the 0.7 and $1 \mathrm{lb} / \mathrm{bbl}$ potassium alum muds. From the sensitivity tests on swelling inhabitation performance, the $0.7 \mathrm{lb} / \mathrm{bbl}$ potassium alum mud was elected to be the best performer. An additional test on the same mud with three shale samples was carried and results were consistent with the previous one.

Rheological measurements were taken for all the mud samples with American Petroleum Institute (API) standards and were based on the Bingham fluid model. The mud density didn't change with different potassium alum concentrations and remained at $8.8 \mathrm{lb} / \mathrm{gal}$. This was due to the small concentrations incorporated in the base mud. All the test muds showed acceptable rheological properties. The best performer mud with $0.7 \mathrm{lb} / \mathrm{bbl}$ potassium alum, had a plastic viscosity of $9 \mathrm{cp}$, apparent viscosity of $10 \mathrm{cp}$, and a yield point of $2 \mathrm{lb} / 100 \mathrm{ft}^{2}$. 
Filtration properties experienced small changes as the potassium alum concentration was increased. Overall, all mud samples yielded low filtration rates. The $0.7 \mathrm{lb} / \mathrm{bbl}$ potassium alum mud had $6.9 \mathrm{~mL}$ filtrate during the 30 minutes test with the filter press and yielded a thin $1.3 \mathrm{~mm}$ mud cake (API recommended thickness is $<2 \mathrm{~mm}$ ).

Finally, a drinking water test kit was used to verify any potential health hazards. The kit was based on the U.S. Environmental Protection Agency (EPA) guideline standards and designed to identify eight common water contaminants: bacteria, lead, pesticide, nitrate, nitrite, $\mathrm{pH}$, hardness, and chlorine. The test was done on the filtrate $0.7 \mathrm{lb} / \mathrm{bbl}$ potassium alum mud. The sample passed all tests, except for $\mathrm{pH}$ and hardness. 


\section{Dedication}

To my family who supported and encouraged me through all my life. There are no words that can express my gratefulness and respect. 


\section{Acknowledgement}

I would like to express my gratitude to my teacher and long time academic advisor Dr. Ilkin Bilgesu for his commitment, guidance, and help throughout this study. Also, I want to thank the chairman of the Petroleum and Natural Gas Engineering department at West Virginia University Professor Sam Ameri for his agreement to be on my committee and his vital insights on the subject. As well, I want to thank the former chairman of Safety and Environmental Management Department at West Virginia University Professor Della-Giustina for his agreement to be a member on my committee and his insights on making the subject of this study as safe and environmentally acceptable as possible. 


\section{Table of Contents}

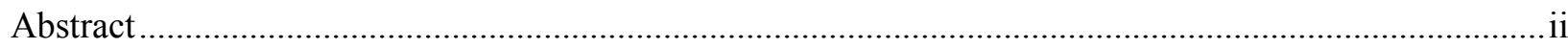

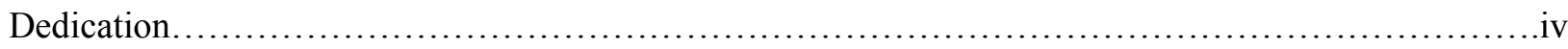

Acknowledgement.........................................................................

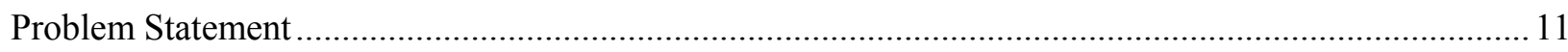

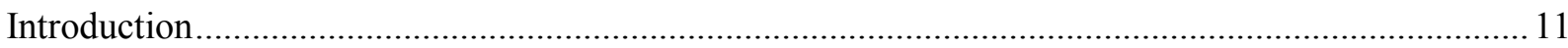

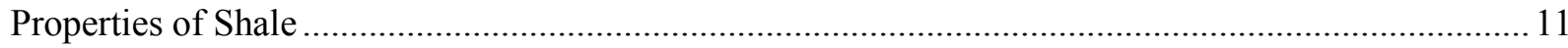

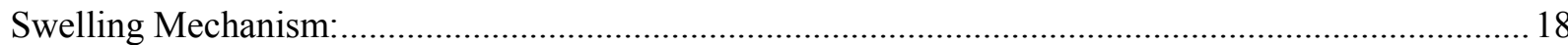

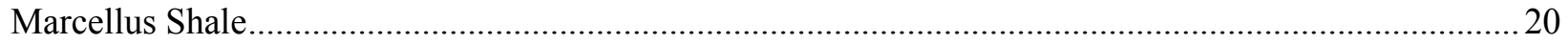

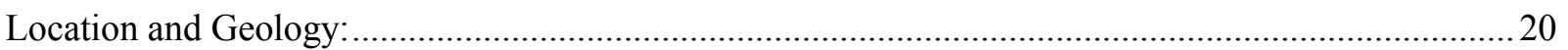

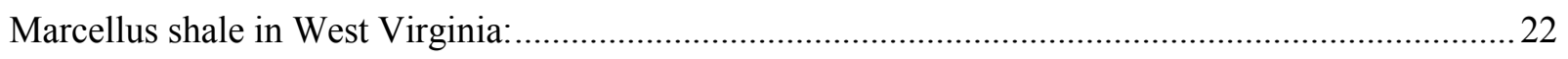

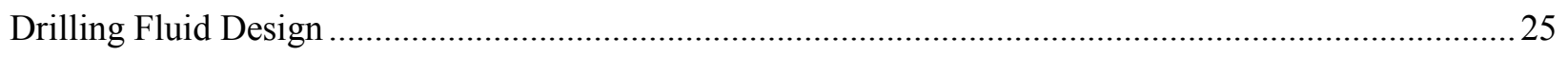

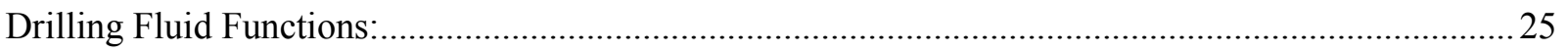

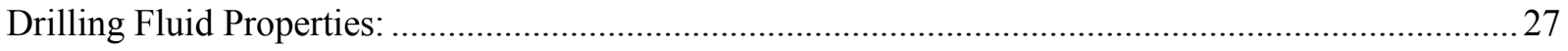

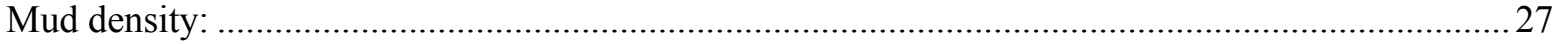

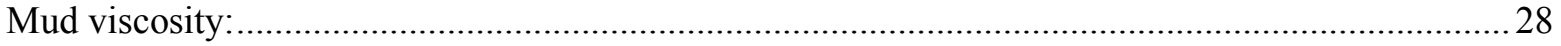

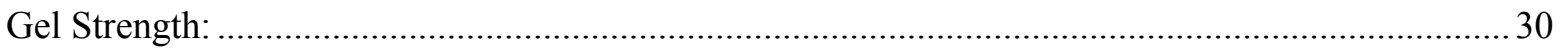

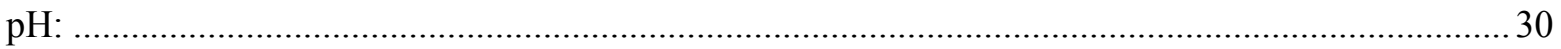

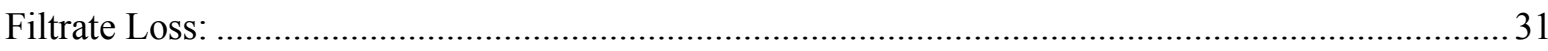

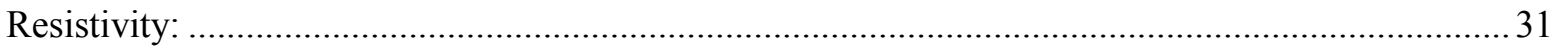

Drilling Fluid Types:

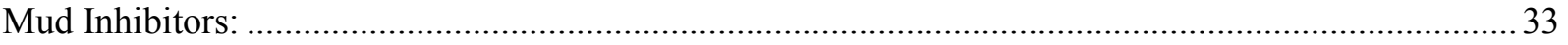

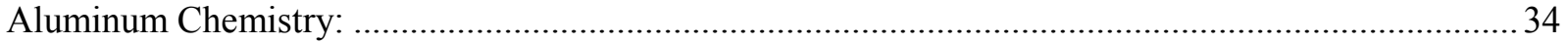

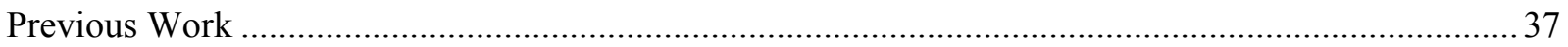

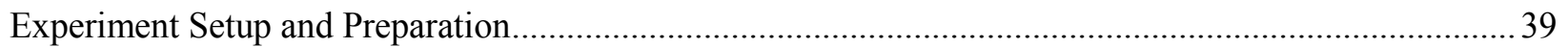

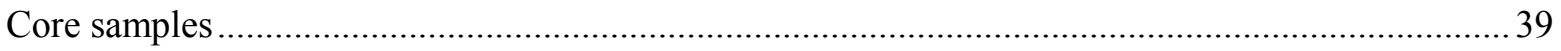

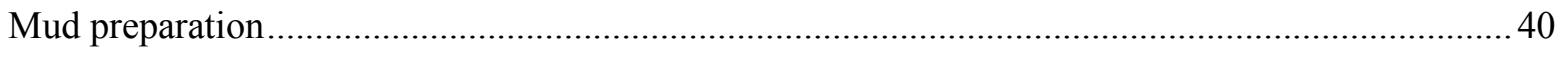

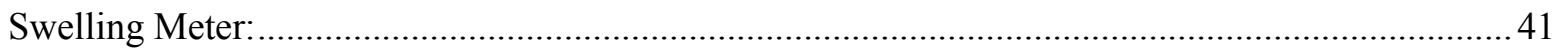

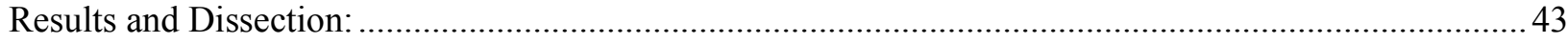

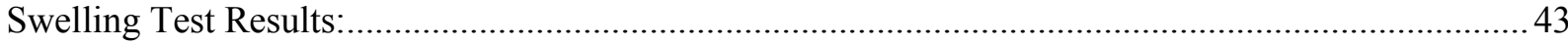

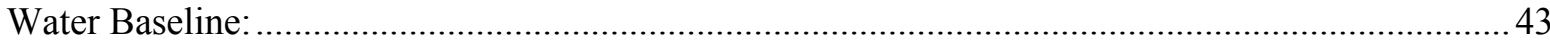

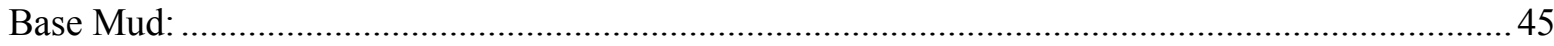

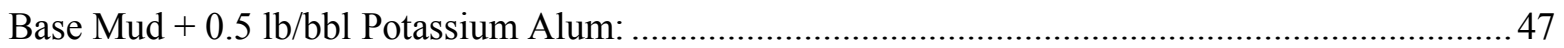




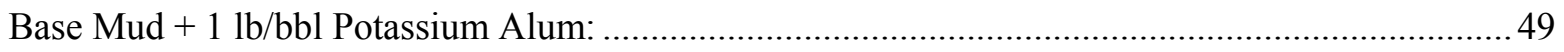

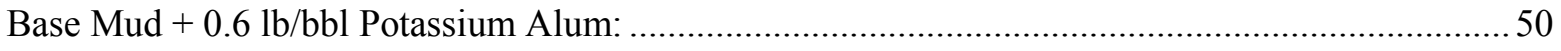

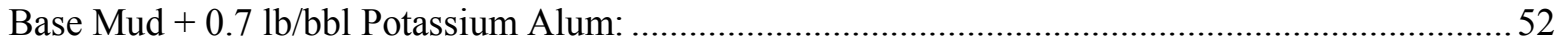

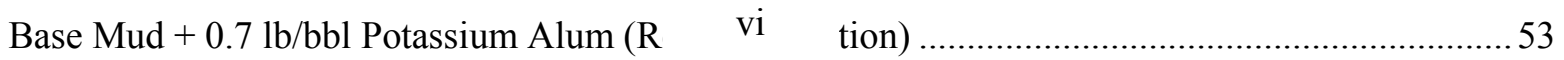

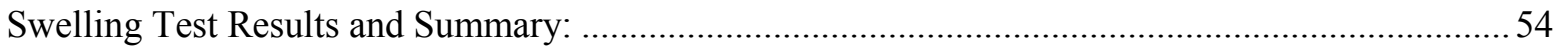

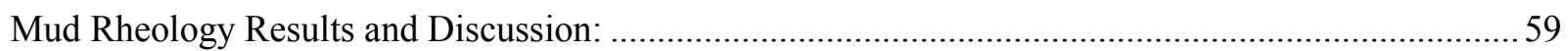

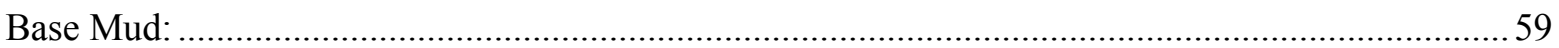

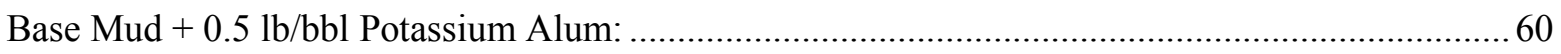

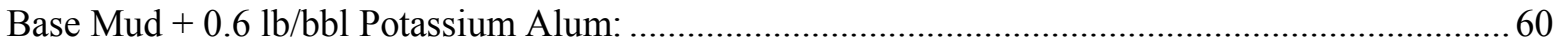

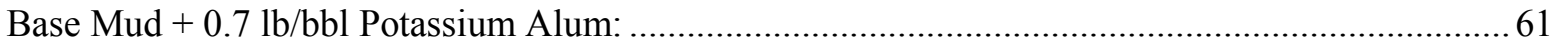

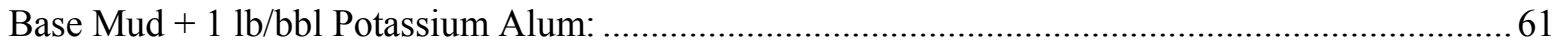

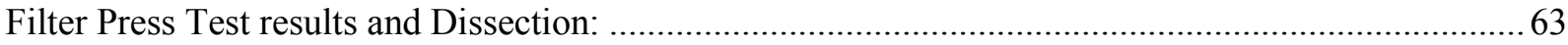

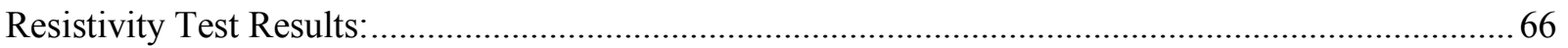

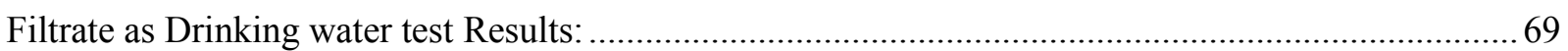

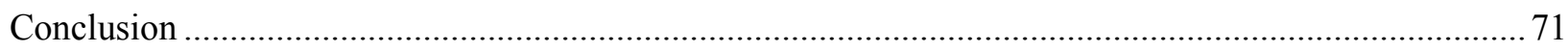

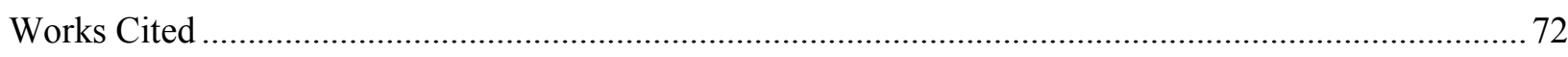

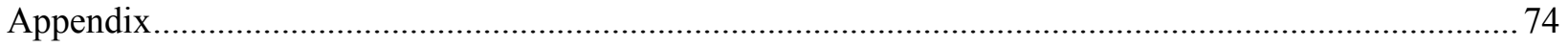

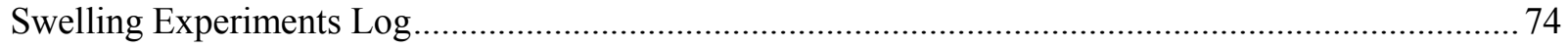




\section{List of Figures}

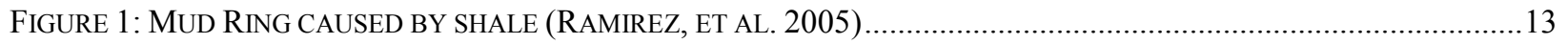

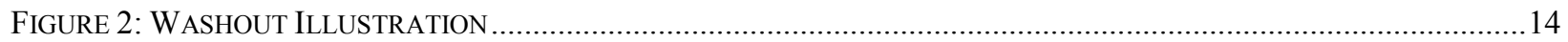

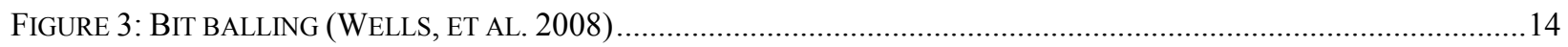

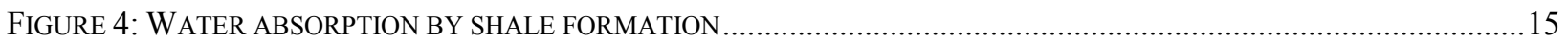

FIGURE 5: FORMATION SWELLING AND CAVING RESULTING IN STUCK PIPE …….......................................................15

FIGURE 6: SWELLING, AND CAVING RESULTING IN HIGH DRAG AND SLOW PENETRATION.............................................16

Figure 7: Wellbore simulation on Pierre Shale at SCHLUmberger CAMBridge Research in CAMBridge,

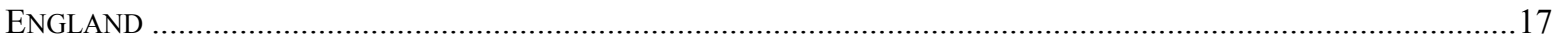

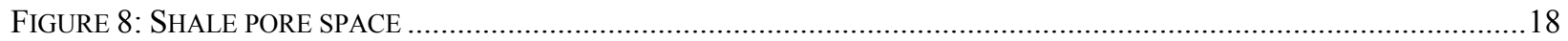

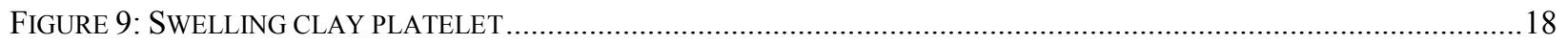

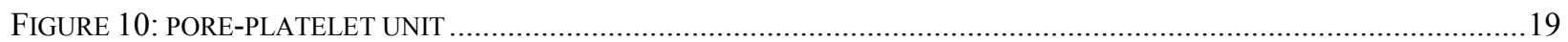

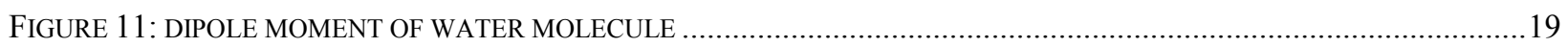

FigURE 12: MAP OF MARCELlUS SHALE FORMATION (WEST VIRGINIA GEOLOGICAL AND ECONOMIC SURVEY) .........20

Figure 13: GeNERALIZED StRatigRAPHIC NOMENClatURE FOR THE MidDLE DEVONIAN STRATA IN THE

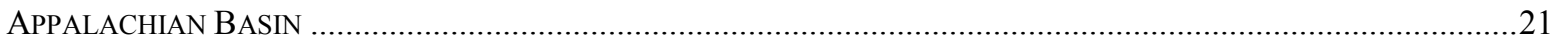

Figure 14: MARCELLUS ThiCKNESS MAP IN FEET (WEST ViRginia GEOLOGICAL AND ECONOMIC SURVEY) ............22

Figure 15: MARCELlus Pressure Regimes (WeSt Virginia Geological AND Economic SuRVey)....................23

FigURE 16: MARCELLUS WELlS AND PERMITS MAP IN WV (Nov.2011) (WEST VIRGINIA GEOLOGICAL AND

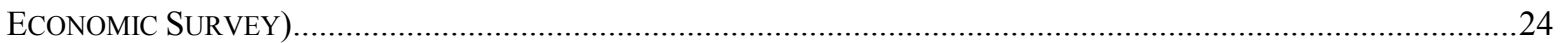

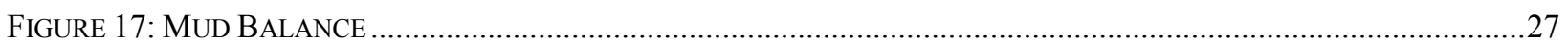

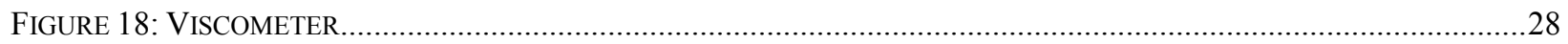

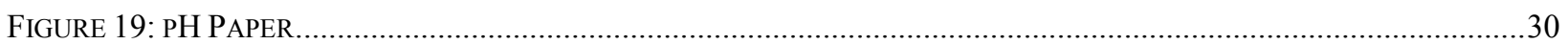

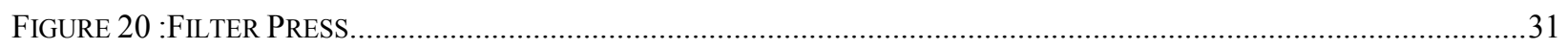

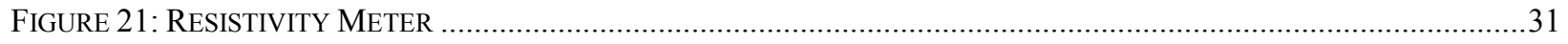

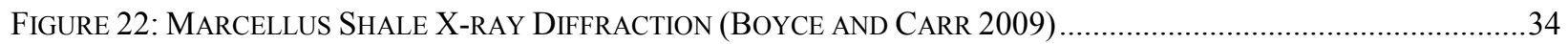

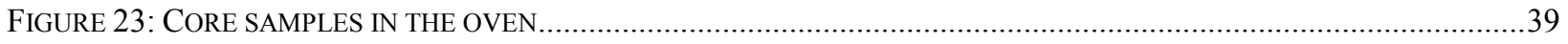

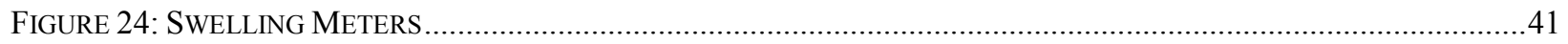

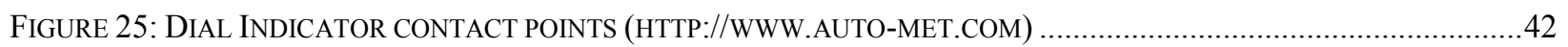

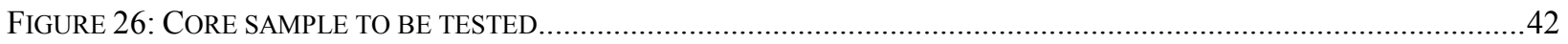

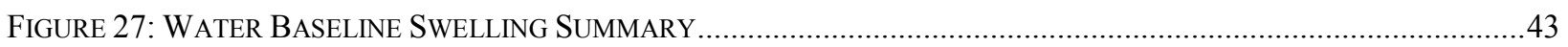

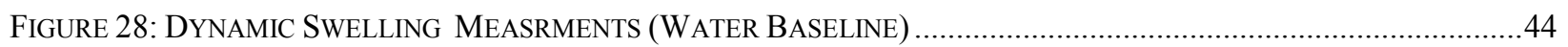

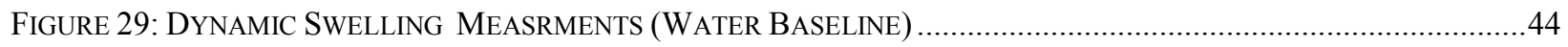

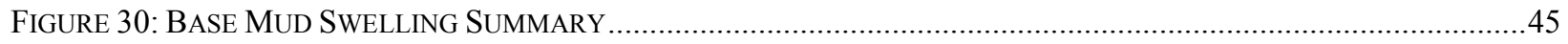

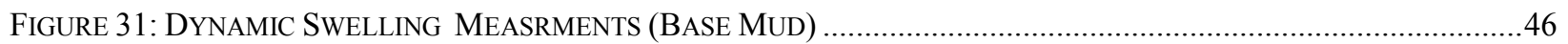

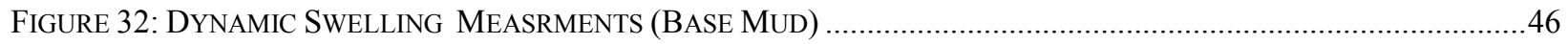

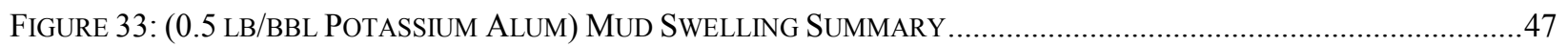

Figure 34: Dynamic Swelling MeASRments (0.5 LB/BBL Potassium Alum) Mud ..............................................48

FIgURE 35: DyNAMIC SWELLING MEASRMENTS (0.5 LB/BBL PotASSIUM ALUM) Mud ..............................................4

Figure 36: DyNAmic SwELling MEASRMENTS (1 LB/BBL PotASSIUM Alum )Mud................................................49

FIGURE 37: 0.6 LB/BBL POTASSIUM ALUM MUD SWELLING SUMMARY ...........................................................50

Figure 38: Dynamic Swelling MEASRments (0.6 LB/Bbl Potassium Alum) Mud ...........................................51

Figure 39: Dynamic Swelling MEASRments (0.6 LB/BbL Potassium Alum) Mud ..........................................51

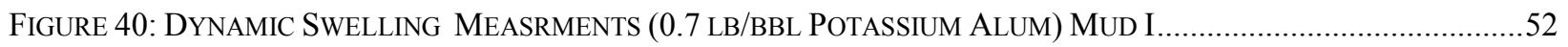

Figure 41: Dynamic SwelLing MeasRments (0.7 LB/BBL Potassium Alum) Mud II .......................................53

FIGURE 42: SWELLING RESULTS SUMMARY, ONE HOUR SCALE .....................................................................................54 


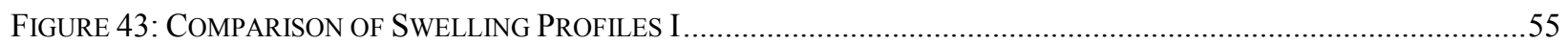

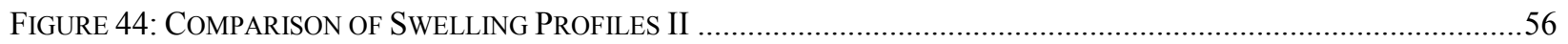

FIGURE 45: PLASTIC VISCOSITY AS A FUNCTION OF POTASSIUM ALUM CONCENTRATION ........................................62

FIGURE 46: APPARENT VISCOSITY AS A FUNCTION OF POTASSIUM ALUM CONCENTRATION....................................62

FIGURE 47: BINGHAM YIELD POINT AS A FUNCTION OF POTASSIUM ALUM CONCENTRATION ..................................62

FIGURE 48: FILTRATE VOLUME AT DIFFRENT CONCENTRATIONS OF POTASSUIM ALUM ............................................64

FIGURE 49: FILTRATE VOLUME WITH DIFFERENT CONCENTRATIONS OF POTASSIUM ALUM ........................................64

FIGURE 50: MUD CAKE THICKNESS AT DIFFERENT POTASSIUM ALUM CONCENTRATIONS .........................................65

FIGURE 51: MUD CAKE THICKNESS AS A FUNCTION OF POTASSIUM ALUM CONCENTRATION ......................................65

FIGURE 52: FILTRATE RESISTIVITY AT DIFFERENT POTASSIUM ALUM CONCENTRATIONS..........................................66

FIGURE 53: FILTRATE RESISTIVITY AS A FUNCTION OF POTASSIUM ALUM CONCENTRATION.....................................67

FIGURE 54: MUD CAKE RESISTIVITY AT DIFFERENT POTASSIUM ALUM CONCENTRATIONS ......................................67

FIGURE 55: MUD CAKE RESISTIVITY AS A FUNCTION OF POTASSIUM ALUM CONCENTRATION ..................................68 


\section{List of Tables}

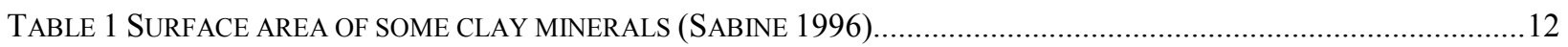

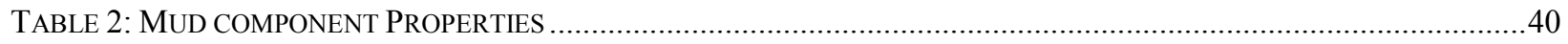

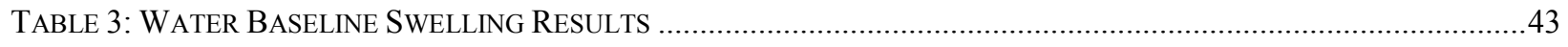

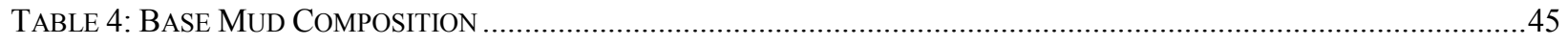

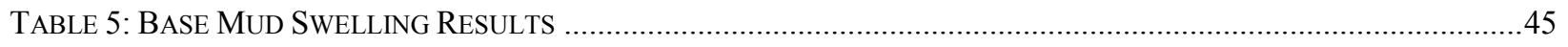

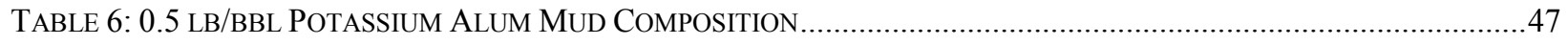

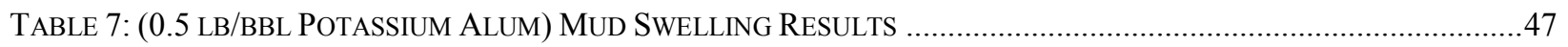

TABLE 8: 1 LB/BBL PotASSIUM ALUM MUd COMPOSITION...........................................................................................49

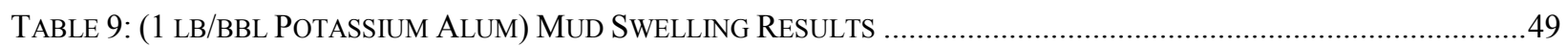

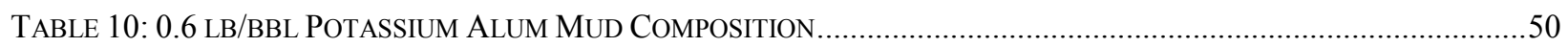

TABLE 11: 0.6 LB/BBL PotASSIUM ALUM MUd SwELLING SUMMARY .............................................................50

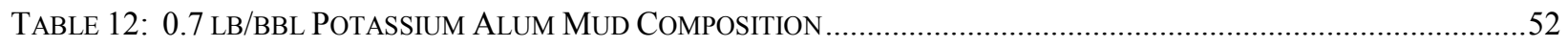

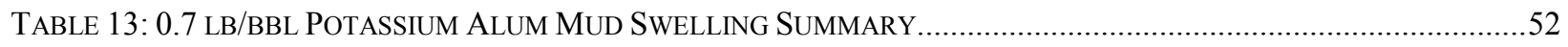

TABLE 14: 0.7 LB/BBL PotASSIUM ALUM MUd SwELLING SUMMARY II ...........................................................5

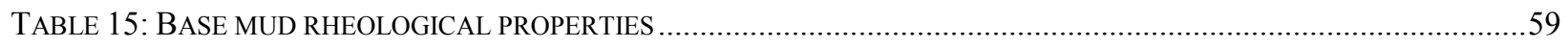

TABLE 16: 0.5 LB/BBL POTASSIUM ALUM MUD RHEOLOGICAL PROPERTIES ….............................................................60

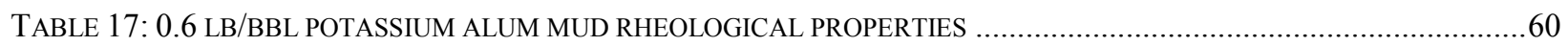

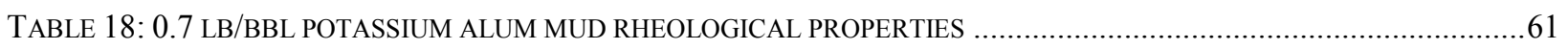

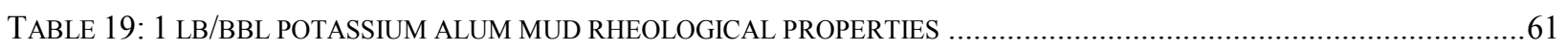

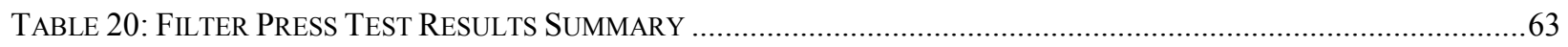

TABLE 21: FILTRATE \& MUD CAKE RESISTIVITIES RESULTS SUMMARY AT DIFFRENT CONCEINTRATION OF POTASSUIM

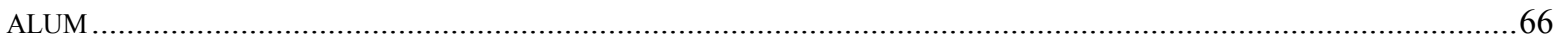

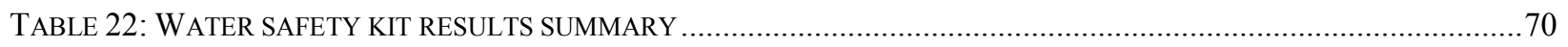




\section{Problem Statement}

\section{Introduction}

One of the major problems in the petroleum industry is wellbore instability. This drilling problem can result in drilling delays, increasing drilling cost, and in sometimes leads to the abandonment of the drilling operation. Drilling operations are very costly by themselves and well instability problems cost the oil industry one billion U.S dollars annually.

Shales account for three fourths of drilled formations. Nonetheless, $90 \%$ of the wellbore instability problems are shale related (Patel 2009). Shale rock instability has been well studied, chemically, mechanically, and even on the micro scale. However, shales are still problematic to deal with, not only in the petroleum industry, but in the mining and construction industries as well. There are around nineteen major shale gas plays in the United States alone. The variation of shales depends on many factors, such as mineralogy, age, and depositional environment. All these factors alter the rock chemical and physical characteristics. However, almost all shales share the instability characteristic and they vary in how unstable they are (Halliburton 2008).

\section{Properties of Shale}

Shales are defined as laminated clay-bearing sedimentary rocks with les that 0.1 microdarcy. Typically, they have a very finely laminated structure and inter-bedded with sandstone or limestone. Bedding layers thickness can range from a millimeter to hundreds of meters. Moreover, these bedding layers are classified as transversely isotropic. This means that material properties along the bedding planes are different from the plane perpendicular to the bedding (Geology.com) 
Most shale rocks bear clay minerals within their matrix. These clay minerals are largely kaolinite, montmorillonite and illite and they are expandable in a process called hydration (Lal 1999). When the clays within shale come in contact with water, hydrogen bonding on the clay surface occurs. Also, a strong bonded molecular layer of water form on the basal crystal surface. More molecular water layers form, with each layer bonding being weaker (D.Clark and Saddok 1993). Moreover, depending on the clay lattice structure, more water is absorbed between layers as well as particle surface. Surface hydration of shale is strong and dependent on the surface area of clays present in their structure. Water is drawn into the shale particle by osmotic force. This force is governed by the salt concentration in the shale and liquid. The hydration of clays results in major problems in drilling and completing oil and gas wells, mainly well instability. Table 1 lists the surface area of slay minerals.

\begin{tabular}{|c|c|}
\hline Clay Mineral & Surface Area $\mathbf{m}^{\mathbf{2}} / \boldsymbol{g}$ \\
\hline hematite & $\mathbf{1 0 . 9}$ \\
\hline goethite & $\mathbf{6 3 . 1}$ \\
\hline amorphous Fe oxide & $\mathbf{2 2 2 . 7}$ \\
\hline Aluminum Oxid C & $\mathbf{1 0 2 . 9}$ \\
\hline gibbsite & $\mathbf{5 6 . 5}$ \\
\hline calcite & $\mathbf{2 2}$ \\
\hline KGa-1 kaolinite & $\mathbf{9 . 1 4}$ \\
\hline KGa-2 kaolinite & $\mathbf{1 9 . 3}$ \\
\hline SWy-1 montmorillonite & $\mathbf{1 8 . 6}$ \\
\hline SAz-1 montmorillonite & $\mathbf{4 8 . 9}$ \\
\hline STx-1 montmorillonite & $\mathbf{7 0 . 3}$ \\
\hline IMt-1 illite & $\mathbf{2 4 . 9}$ \\
\hline
\end{tabular}

Table 1: Surface area of some clay minerals (Sabine 1996) 
Shale formations are very challenging to drill and thus expansive too. The main reason behind this is wellbore instability. This drilling problem can cause drilling delays and therefore increasing the drilling cost significantly (Halliburton 2008). Unfortunately, wellbore instability problems can result in the abandonment of a drilling operation. These problems include:

\section{Swelling:}

Clay swelling occurs when water enters the formation. Clay swelling can be caused by ion exchange or changes in salinity. The nature of the reaction depends on the structure of the clays and their chemical state at the moment of contact.

\section{Heaving and sloughing:}

This occurs when a partial or complete collapse of the walls of a hole resulting from internal pressures primarily caused by swelling. As a result, the drilling bit and the drill pipe might get stuck with shale cuttings adherence to them. This is known as "mud rings" (Figure 1)

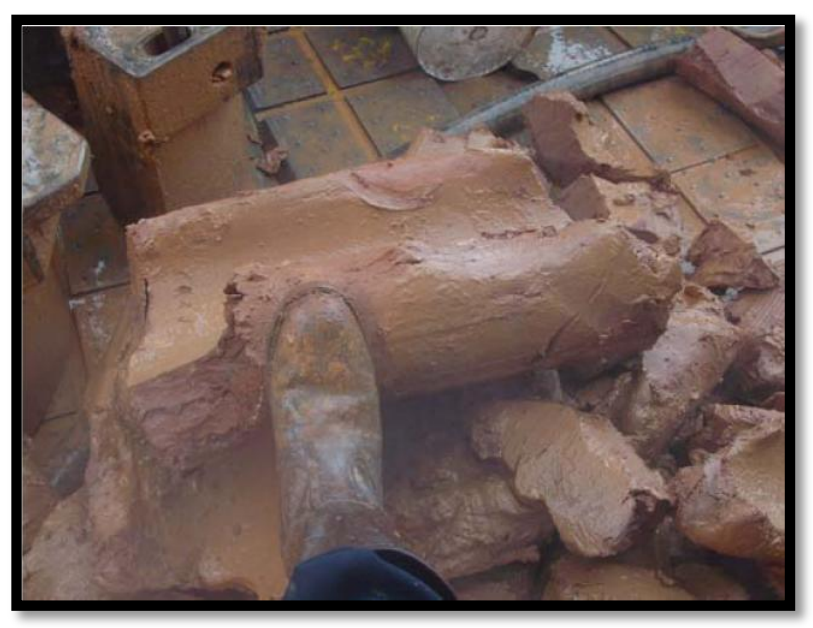

Figure 1: Mud Ring caused by shale (Ramirez, et al. 2005) 


\section{Washout:}

A washout in an openhole section is larger than the original hole size or size of the drill bit. It can be caused by excessive bit jet velocity, soft or unconsolidated formations, in-situ rock stresses, mechanical damage by "Bottom Hole Assembly" (BHA )components, and swelling or weakening of shale as it contacts water (Figure 2).

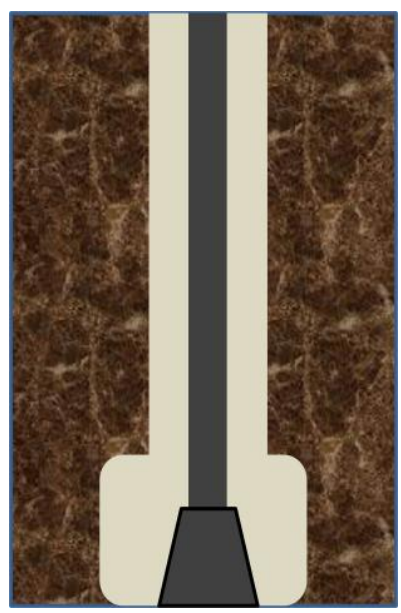

Figure 2: Washout Illustration

\section{Bit balling:}

Bit balling refers to the adhesion of sticky drill cuttings to the drill pipe, drill collar, and between the teeth of the drilling bit. A bit with such material attached to it is called a balled-up bit (Figure 3).

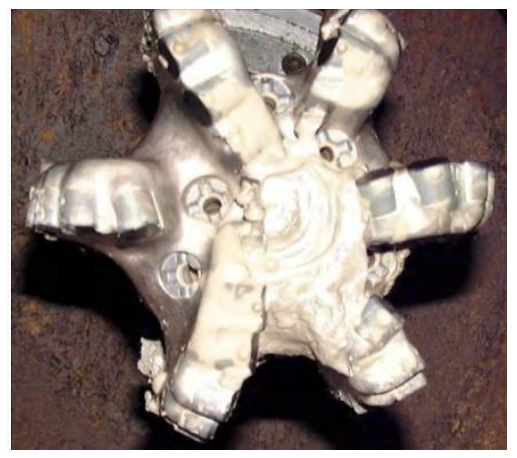

Figure 3: Bit balling (Wells, et al. 2008) 


\section{Stuck pipe:}

Stuck pipe is a drill string that cannot be rotated or moved vertically. There are many reasons that can cause a stuck pipe such as an inadequate hole cleaning, high mud weight, caving and swelling. For example, when shale swells, the diameter of the hole could shrink causing the bit to get stuck, or a caving that will cause the drilling pipe to get stuck at that point (Figures $4 \& 5$ ).

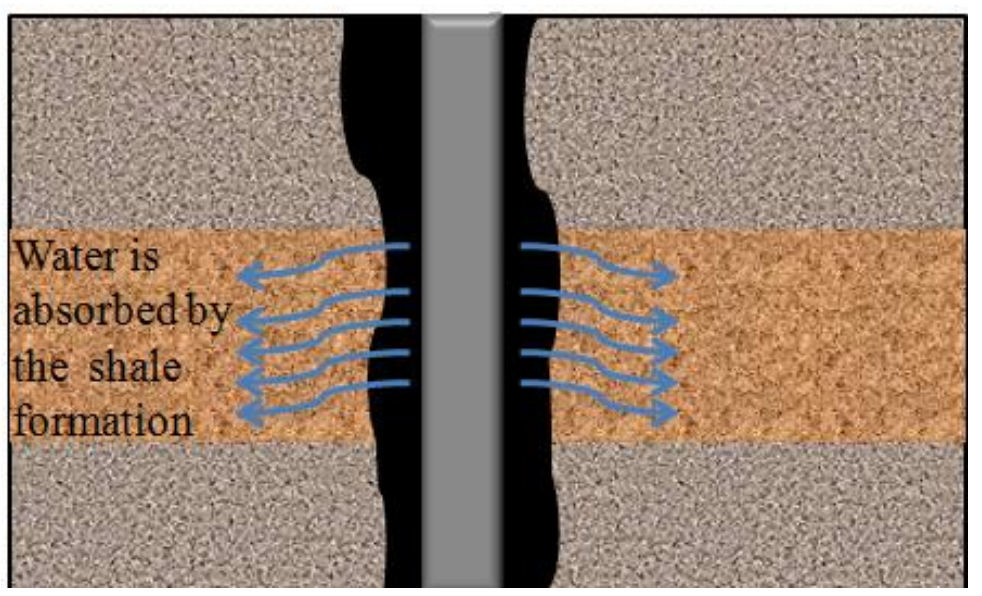

Figure 4: Water absorption by shale formation

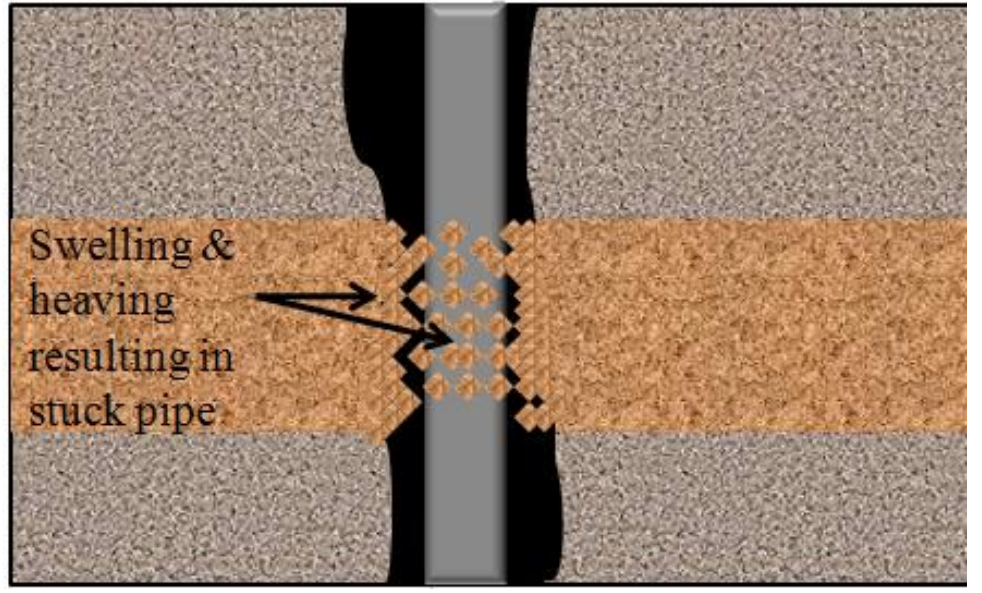

Figure 5: Formation swelling and caving resulting in stuck pipe 


\section{High drag and slow penetration rate:}

All the heaving, balling up, and swelling that aren't enough to get the pipe stuck, will at least cause high drag and the drilling string due to high friction and load. This will slow the penetration speed and even might damage parts of the drilling string because of the high load, in addition to low drilling efficiency (Figure 6).

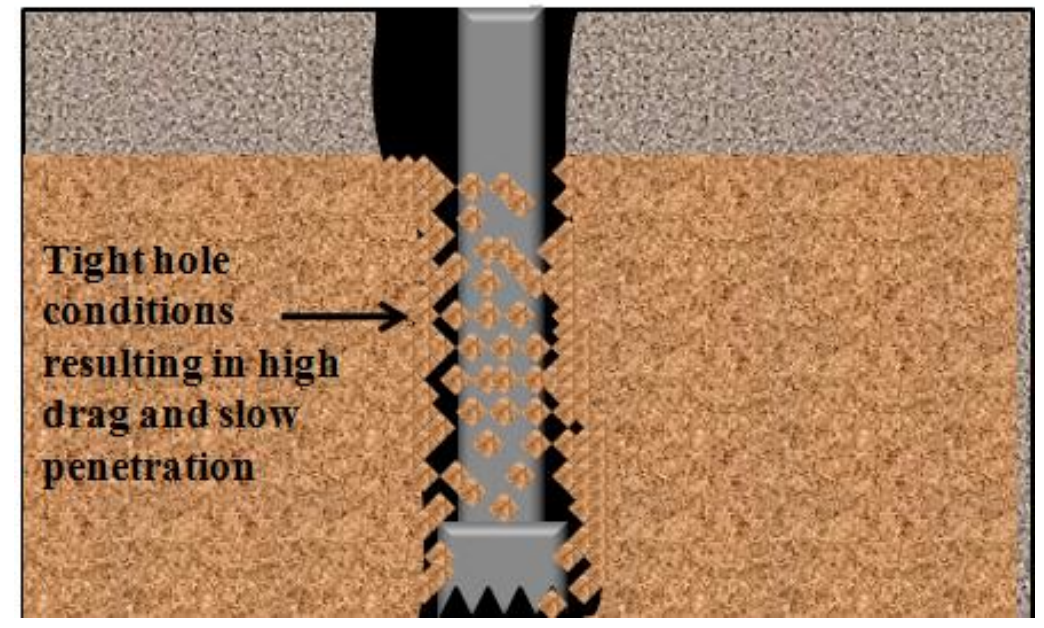

Figure 6: Swelling, and caving resulting in high drag and slow penetration

It is important to know that some of these problems can be connected to each other. For example, hole sloughing, bit baling, and hole fill can cause high drag and slow penetration. This problem can be caused by formation swelling and/or cuttings swelling in the bore hole. Stuck pipe can occur from swelling and/or hole fill due to the insufficiency of wellbore cleaning due to cutting swelling or shale dispersion. These problems can also cause other problems like, poor logging (D.Clark and Saddok 1993). 
Schlumberger Cambridge Research in Cambridge, England, performed a test on Pierre shale in a wellbore simulator. The sample was exposed to mud containing fresh water and bentonite gel. Water has entered the shale causing it to swell and weakening the formation. Continuous flow of mud has eroded the borehole leaving an enlarged hole that would be hard to $\log$ and complete.

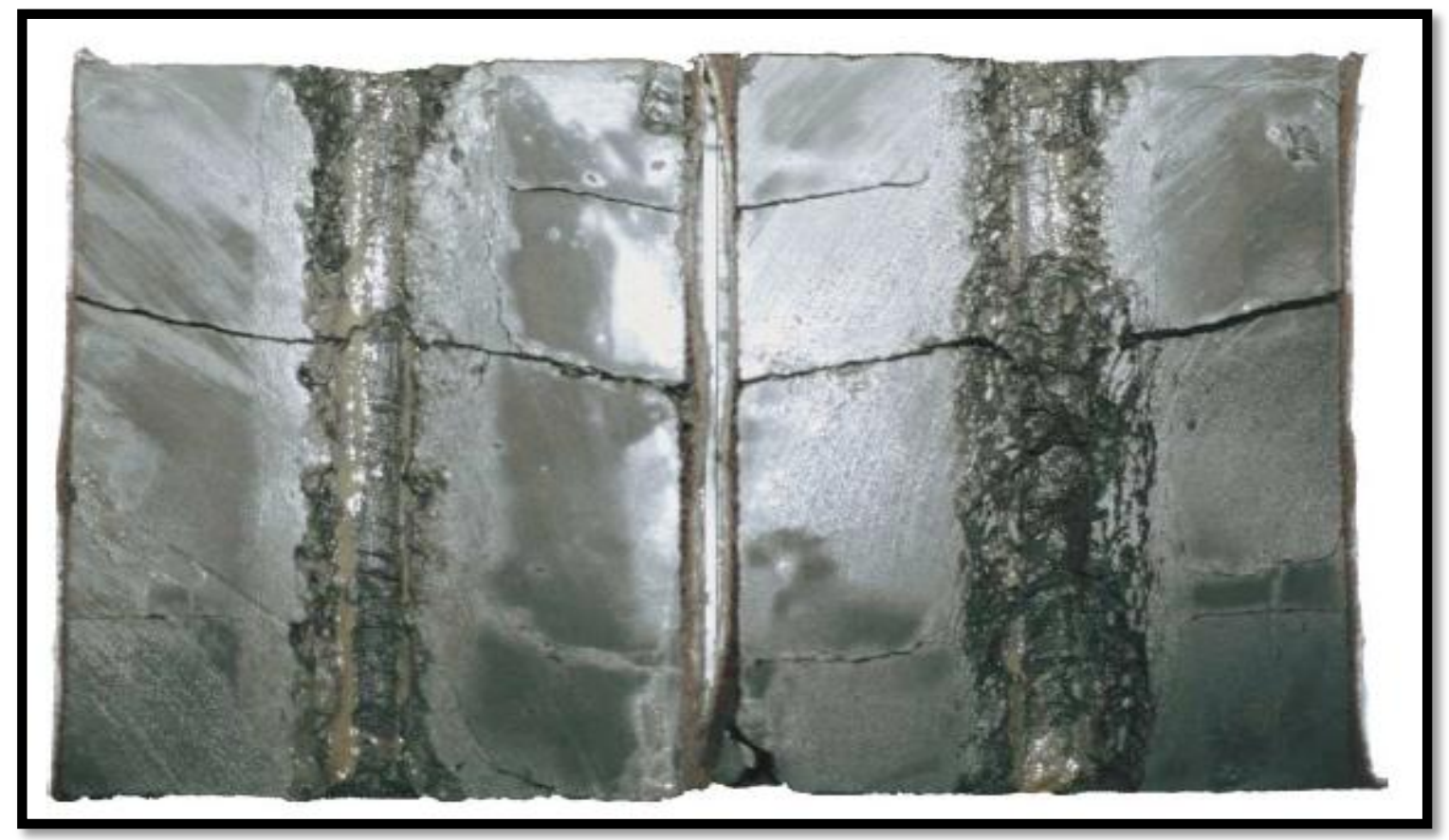

Figure 7: Wellbore simulation on Pierre shale at Schlumberger Cambridge Research in Cambridge, England (Lal. 1999) 


\section{Swelling Mechanism:}

The swelling characteristics of any shale are dependent on its composition of swelling clays in its matrix. Figure 8 represents a pore space within a shale sample. The pore space has some water in it with water activity aw,pore and pore pressure $P_{o}$. Figure 9 represents a clay platelet space which is negatively charged and has water with water activity aw,platelet . The pore space and the clay platelet are connected forming a pore-platelet unit (Figure 10) (Hong Wang 2010). In general water activity in the clay platelet is lower than its counterpart of the pore space. In water, oxygen attracts electrons much more strongly than hydrogen. As a result, net positive charge on the hydrogen atoms, and a net negative charge on the oxygen atom are formed; giving each water molecule a net dipole moment (Figure 11). The highly negatively charged clay platelet attracts water molecules and traps them within in quest of charge equilibrium (Lal. 1999). This causes the clay platelet to expand. Additional swelling takes place by the electrostatic repulsion caused by the water molecules orientation in the clay platelet.

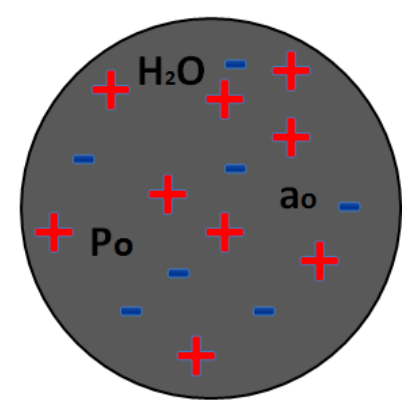

Figure 8: Shale pore space

Figure 9: Swelling clay platelet 


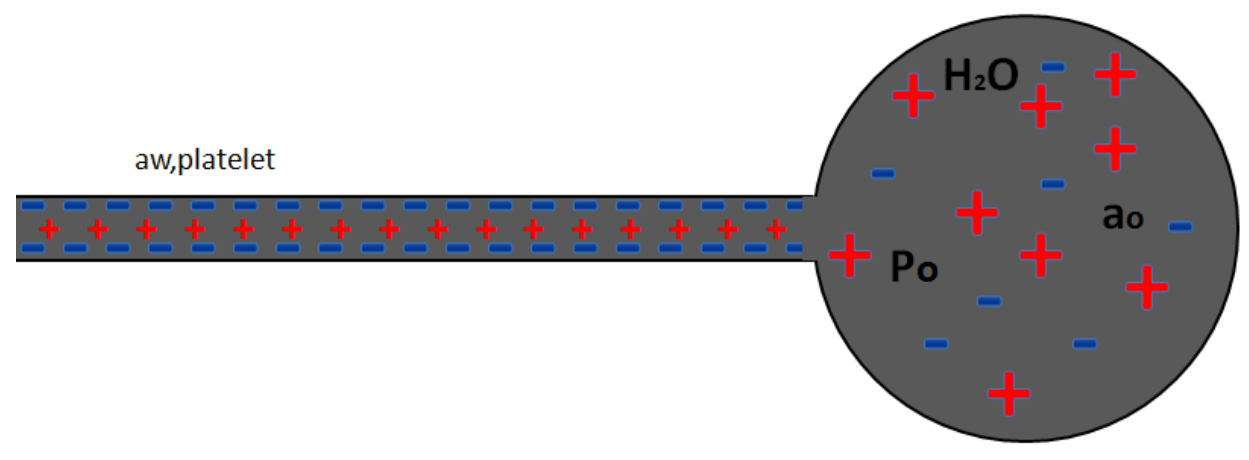

Figure 10: pore-platelet unit

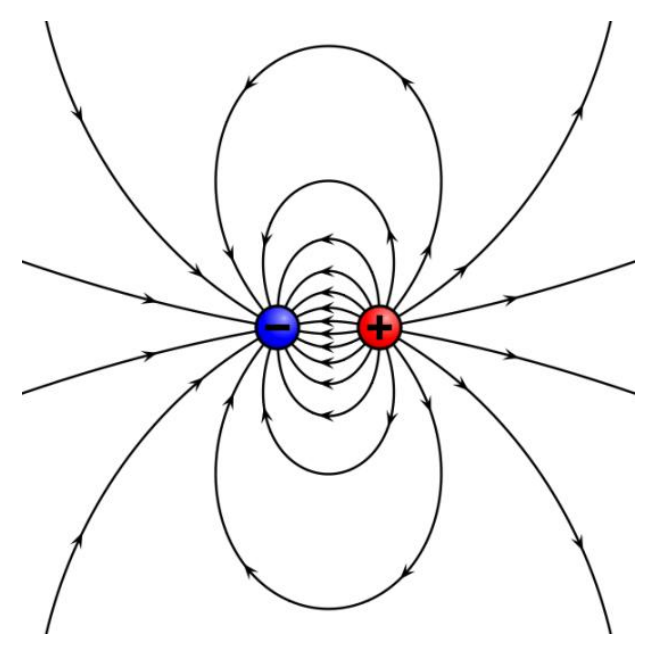

Figure 11: dipole moment of water molecule 


\section{Marcellus Shale}

\section{Location and Geology:}

The Marcellus shale is a marine sedimentary rock found in the North East of the United States of America. Marcellus shale extend from the northern tier of New York to northern and western Pennsylvania, eastern Ohio, western Maryland and most of West Virginia. The Marcellus Shale covers an area of approximately 95,000 square miles (Figure 12). The average thickness ranges from $50 \mathrm{ft}$ to 200 feet. Generally, it becomes thicker to the east. It is mostly black in color; however, shallow shale located in the upper portion of the formation is lighter in color. It has been estimated that the entire play holds between 516 to 1,500 Tcf with recent estimated ultimate recovery (EUR) of 489 Tcf. (Projecting the Economic Impact of Marcellus Shale Gas Development in West Virginia 2010)

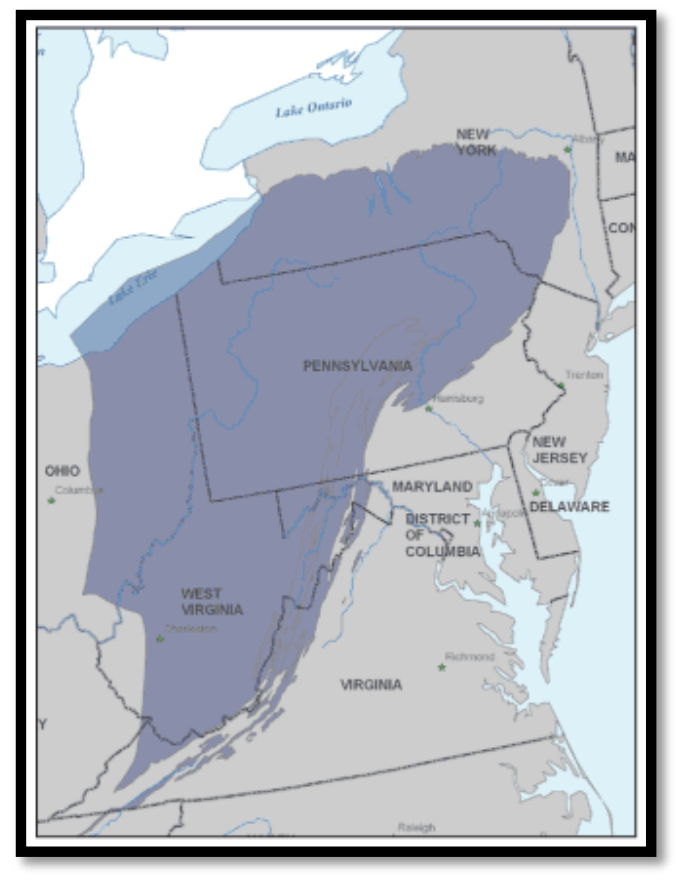

Figure 12: Map of Marcellus shale formation (West Virginia Geological and Economic Survey) (http://www.wvgs.wvnet.edu/) 
The Marcellus is the lowest unit of the Devonian age Hamilton Group, and is divided into several sub-units (Figure 13). It contains interbedded limestone layers due to sea level variation during its deposition around 400 million years ago. The black shale was deposited in relatively deep water deprived of oxygen.

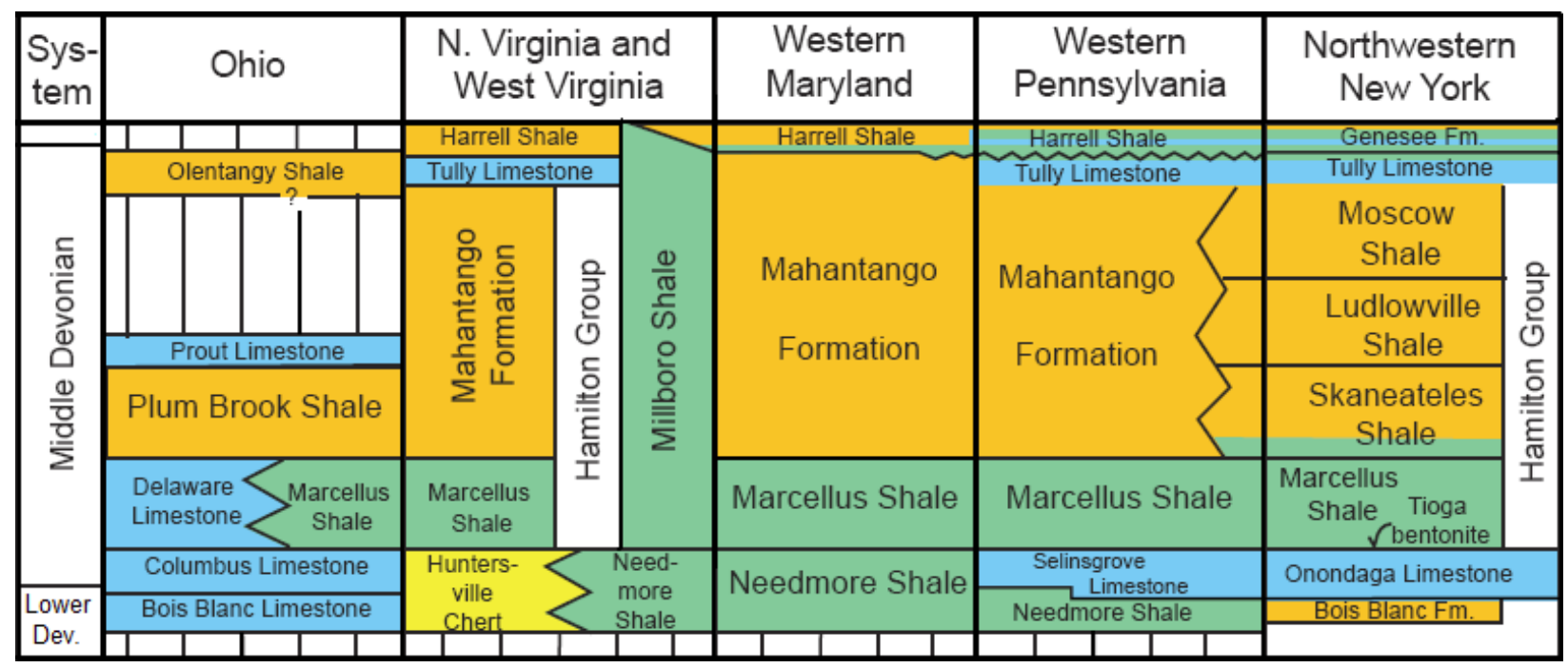

Figure 13: Generalized stratigraphic nomenclature for the Middle Devonian strata in the Appalachian Basin (Boyce and Carr 2009) 


\section{Marcellus shale in West Virginia:}

In West Virginia Marcellus Shale is present throughout the state, except in the very southwest and some of the very east parts of the state. It covers an estimated area of $6,985,000$ acres of West Virginia, with an estimated EUR within the range of 98 Tcf to 150 Tcf (Projecting the Economic Impact of Marcellus Shale Gas Development in West Virginia 2010). The thickness varies across the state, where it's thickest in northeast-central counties and gradually gets thinner towards the southwest (Figure 14).

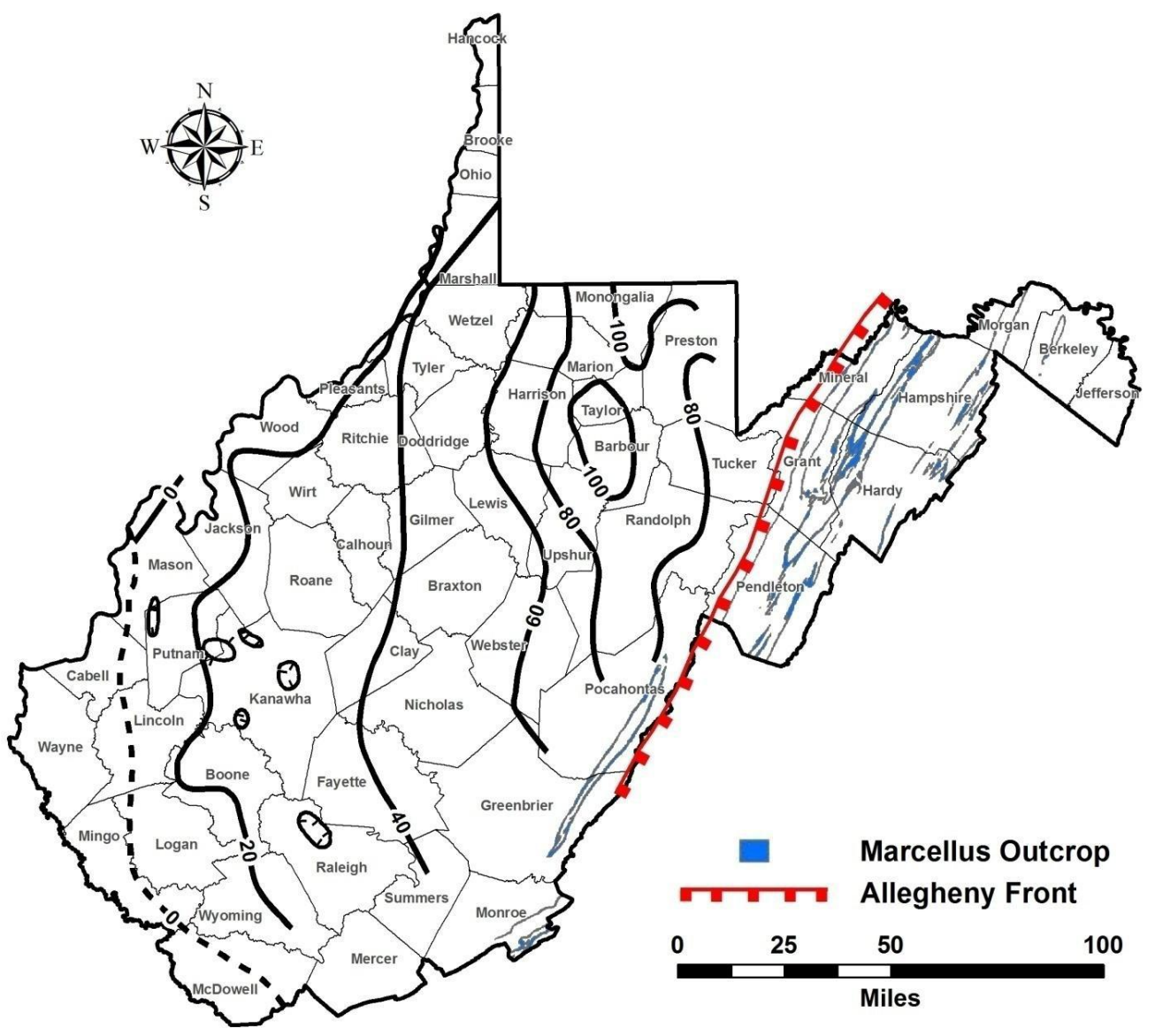

Figure 14: Marcellus Thickness Map in feet (West Virginia Geological and Economic Survey) (http://www.wvgs.wvnet.edu/) 
The Marcellus shale is associated with different pressure regimes in West Virginia. In general it is under-pressured in the southwest, normal to potentially over-pressured in the northeast, and a transitional regime in the area in between (Figure 15).

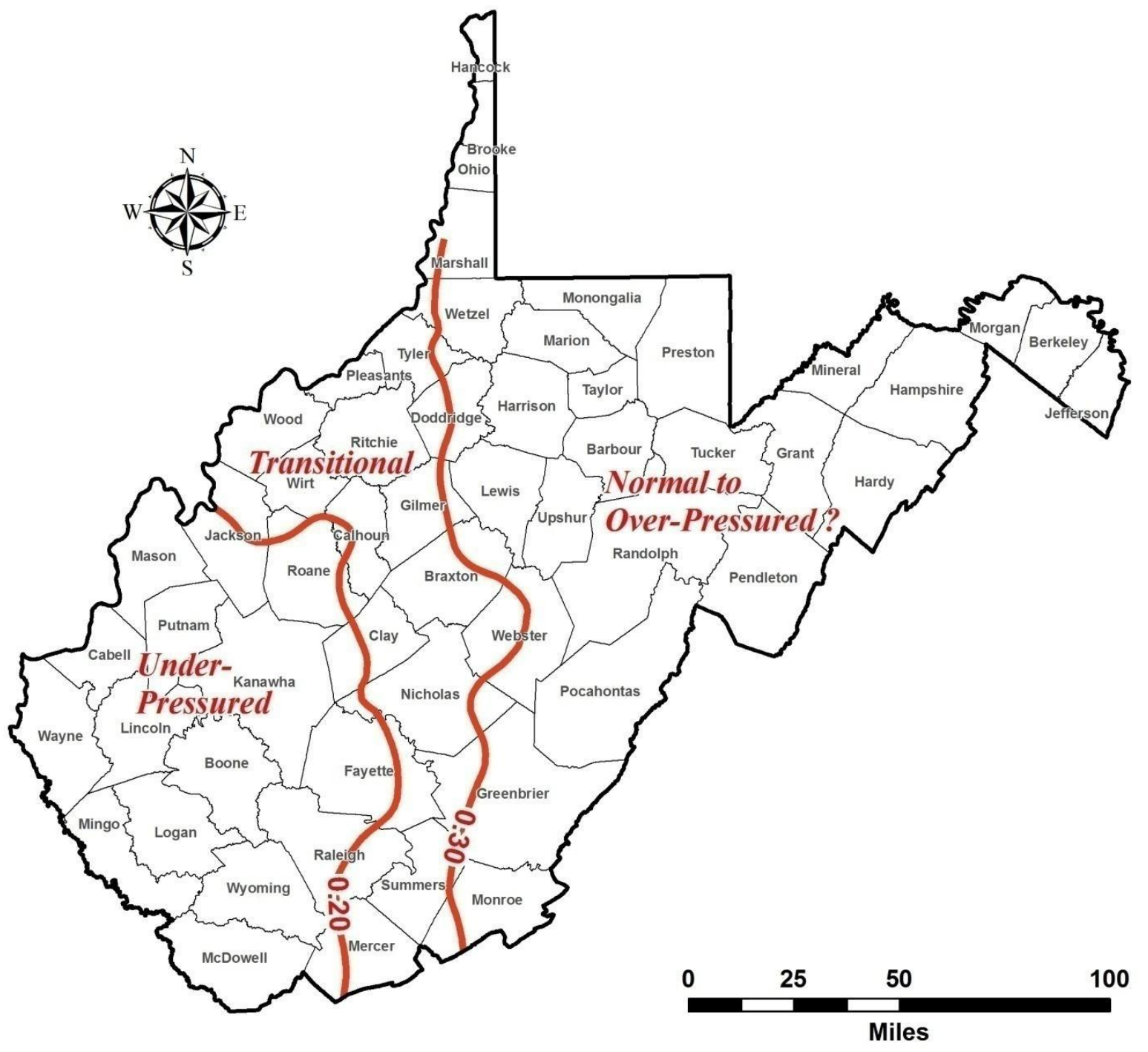

Figure 15: Marcellus Pressure Regimes (West Virginia Geological and Economic Survey)

(http://www.wvgs.wvnet.edu/) 
As of November 10, 2011 according to West Virginia Geological and Economic Survey (WVGES), 1515 wells have been completed in the Marcellus shale formation and 1352 new drilling permits have been issued. Figure 16 the map of Marcellus shale wells (red) and permits (yellow) in West Virginia.

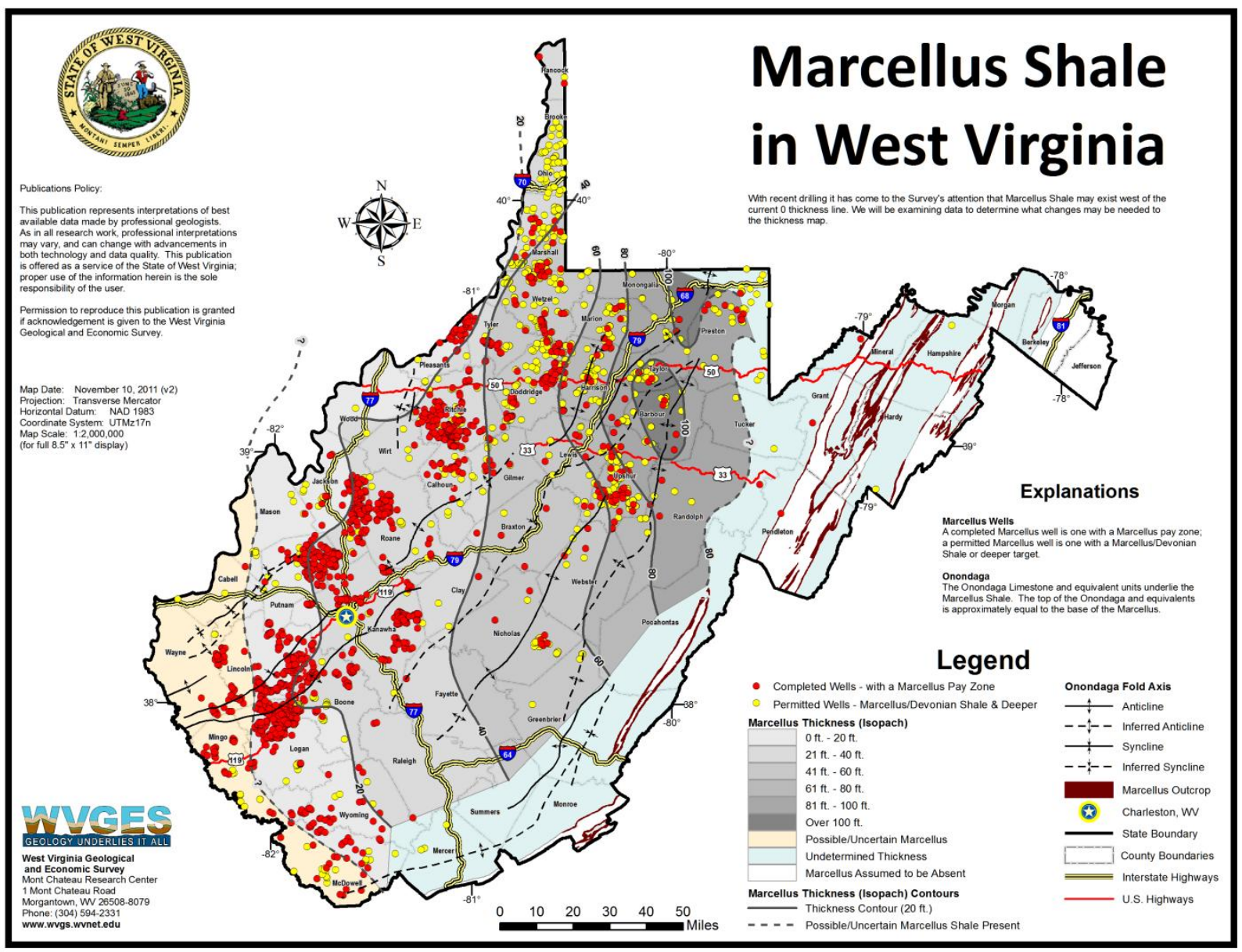

Figure 16: Marcellus Wells and permits map in WV (Nov.2011) (West Virginia Geological and Economic Survey) (http://www.wvgs.wvnet.edu/)

Completed Wells with a Marcellus Pay Zone

Permitted Wells with Marcellus/Devonian and deeper 


\section{Drilling Fluid Design}

\section{Drilling Fluid Functions:}

\section{Remove cuttings from well}

As the drilling fluid is pumped through the drill string, it carries the rock excavated by the drill bit up to the surface. The efficiency of this process depends on the cuttings size, shape, density, and mud circulation velocity.

\section{Suspend and release cuttings}

In static conditions, the mud should be able to suspend cuttings and preventing them from settling at the bottom of the hole. The settling of cutting at the bottom is called sagging and can cause many problems, such as stuck pipe and bridging.

\section{Control formation pressures}

In over-balanced conditions, the pressure exerted by the mud is higher than the formation pressure. This allows well control, which means that uncontrollable flow of formation fluids into the wellbore and preventing blow-outs. The hydrostatic pressure of the drilling fluid is manipulated by its density, where:

\section{Hudrostatic Pressure $(p s i)=\rho \times 0.052 \times D$}

Where:

$\mathrm{P}$ is the mud density in $\mathrm{lb} / \mathrm{gal}$

0.052 is a unit conversion factor

$\mathrm{D}$ is the true vertical depth in $\mathrm{ft}$ 


\section{Seal permeable formations}

As the mud column pressure exceeds formation pressure, mud filtrate invades the formation, and solids from the mud accumulate on the walls of the hole forming what's known as mud cake. A good mud cake should be thin and have low permeability. This will protect the formation from damage and provide support to the borehole wall.

\section{Maintain wellbore stability}

In low permeability formations such as shale, mud cake can't be formed. This leaves the formation vulnerable to swelling and erosions. However, the chemical composition of the drilling fluid should provide means of wellbore stability. Usually, this is achieved by using adding swelling inhibitors, such as salts.

\section{Cool and lubricate the bit.}

Heat is generated at the drill bit from friction against rock and in drill pipe rubbing against well casing. As the mud is circulated through the drill string, it transfers the heat away. This process protects the drilling string from getting damaged, providing it with a longer operating-life. 


\section{Drilling Fluid Properties:}

\section{Mud density:}

Mud weight is measured in lb/gal (pounds per gallon) with a mud balance. In a water based mud, the weight is increased by adding solids such as clay or weighing agents. As mentioned earlier, the mud column exerts hydrostatic pressure against the wellbore wall. Therefore, depending on the formation pressure being drilled, mud density is manipulated to overcome that pressure. High pressure formations require higher mud densities to prevent blow-outs from occurring. Nonetheless, nominal and low formation pressure will require lighter muds; just enough to overbalance the pressure. Too high mud weight will cause formation damage and might cause unwanted formation fractures. Given the formation pressure trends and depths of the Marcellus shale in West Virginia, drilling fluids ranging from water with $8.32 \mathrm{lb} / \mathrm{gal}$ to $10 \mathrm{lb} /$ gal will most likely be suitable.

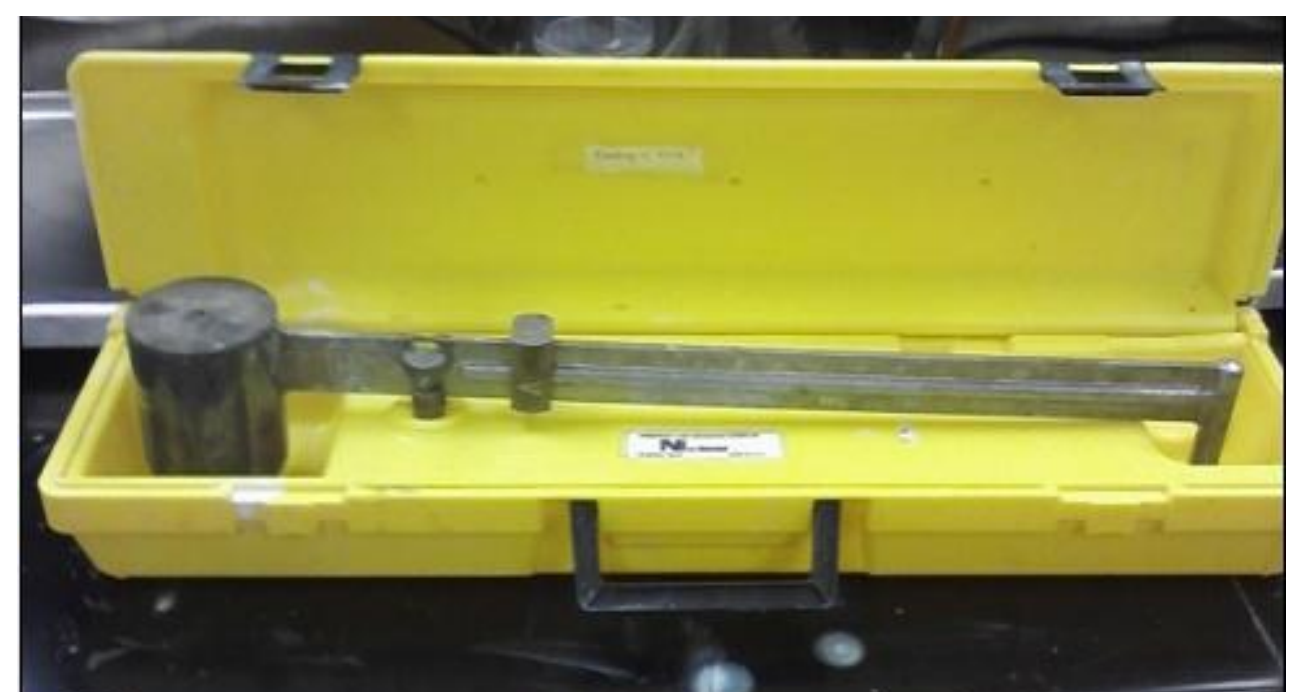

Figure 17: Mud Balance 


\section{Mud viscosity:}

\section{Plastic Viscosity (PV):}

It is parameter based on the Bingham plastic model derived from the slope of the shear stressshear rate. Using a Viscometer, PV can be derived from the $600 \mathrm{rpm}$ reading minus the $300 \mathrm{rpm}$ reading and it is measured in centipoises (cp). In general, low plastic viscosity muds yield faster penetration rates due to the low viscosity of mud at the bit. High plastic viscosity muds have higher capabilities in lifting cuttings from the bottom of the borehole to the surface. However, high plastic viscosity muds can cause higher frictional pressure losses which will affect the drilling efficiency.

$$
P V=600_{\text {rpm reading }}-300_{\text {rpm reading }}
$$

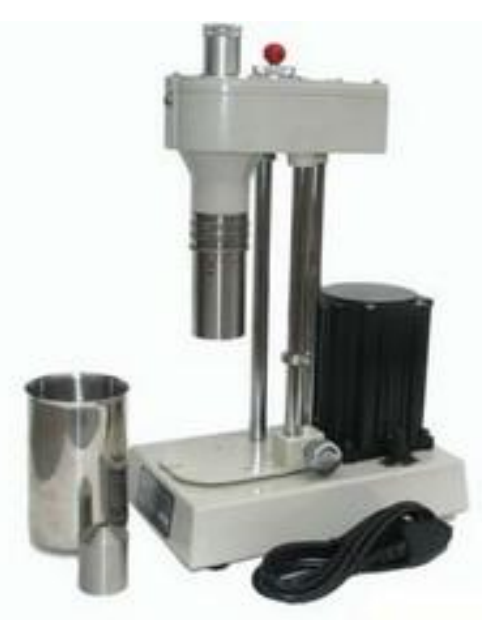

Figure 18: Viscometer 


\section{Apparent Viscosity:}

Apparent viscosity is the viscosity of a fluid measured at the shear rate specified by API. In the Bingham plastic rheological model, apparent viscosity is one-half of the viscometer dial reading at $600 \mathrm{rpm}$.

$$
P A=\frac{1}{2} 600_{\text {rpm reading }}
$$

\section{Yield Point (YP):}

Yield point is defined as the resistance of the drilling fluid to initial flow, or the stress needed to start fluid movement. YP is derived using the viscometer by subtracting plastic viscosity PV from the $300 \mathrm{rpm}$ dial reading on the viscometer and it is measured in $1 \mathrm{bf} / 100 f t^{2}$. This value is used to determine the ability of the drilling fluid to carry cuttings to the surface. Non-Newtonian fluids are associated high yield points, and are able to carry cuttings better than lower yield point fluids of the same density. Deflocculants are used to increase the yield point of a drilling fluid, while Flocculants are used to decrease it.

$$
Y P=P V-300_{\text {rpm reading }}
$$




\section{Gel Strength:}

It is the ability of the drilling fluid to suspend cuttings in static condition. Gel strength is derived from the viscometer as well. The drilling fluid has to be agitated by setting the viscometer to 600 rpm. Then the viscometer is set to zero rpm and the mud is left to settle for 10 seconds. The viscometer then is set to $3 \mathrm{rpm}$ and the maximum dial reading is reported in $\mathrm{lbf} / 100 \mathrm{ft} 2$. Also, there is a 10 minutes gel strength test that can be performed in the same manner.

\section{pH:}

It is a measure of the acidity or basicity of an aqueous solution. The $\mathrm{pH}$ scale ranges from 0 to 14, where solutions with a $\mathrm{pH}$ less than 7 are acidic and solutions with a $\mathrm{pH}$ greater than 7 are basic or alkaline. $\mathrm{pH}$ can be measured using $\mathrm{pH}$ paper or digital $\mathrm{pH}$ meter.

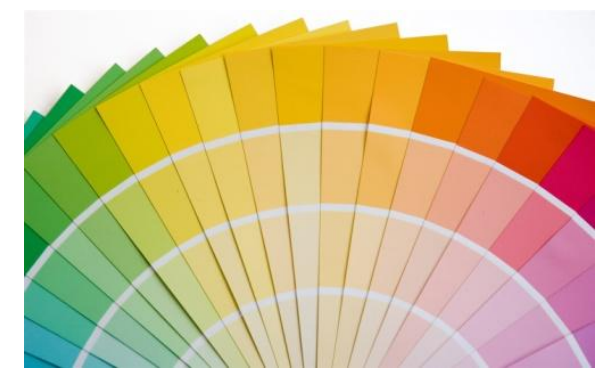

Figure 19: pH Paper 


\section{Filtrate Loss:}

This test shows the fluid loss behavior of the drilling fluid as it is compressed with 100 psi pressure in a cylinder against a filter paper for 30 minutes. As the fluid is filtered out, solids from the mud will accumulate on the filter paper forming a mud-cake. A good drilling fluid will form a thin and resilient mud-cake with low permeability. This prevents the drilling fluid from invading permeable formations and providing support to the wellbore wall.

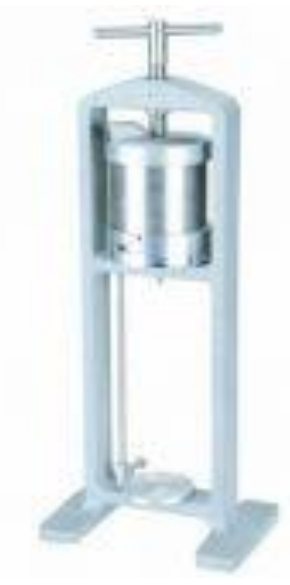

Figure 20 :Filter Press

\section{Resistivity:}

The resistivity of any drilling fluid depends on its composition, and it is an important parameter in resistivity logging. In resistivity logging high resistivity could potentially be a hydrocarbon bearing zone. The mud resistivity is measured using a resistivity meter and reported in ohms.

Figure 21: Resistivity Meter

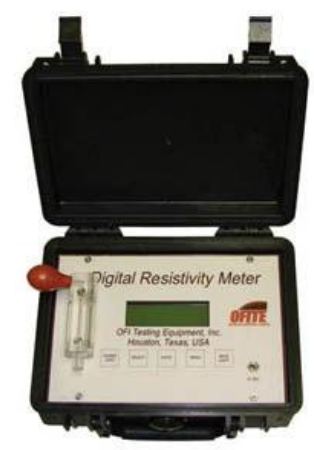




\section{Drilling Fluid Types:}

There are three main types of drilling fluids; water-based (WBM), oil-based (OBM) and synthetic-based (SBM). Technically, OBM and SBM drilling fluids are the best suited for drilling shale formations because they don't interact with shale (Ramirez, et al. 2005). They provide stability of borehole and cuttings, and efficient solids removal. Oil and synthetic oil based muds have high lubricity, higher penetration rate and withstand higher temperatures than water-based muds.

Regardless of their high performance, they have a downside. They are very expensive, difficult to mix, prone to lost circulation, less environmentally acceptable than water-based muds. Furthermore, the application of OBM or SBM requires the following:

1. Special authorization of usage in the area.

2. Expensive cuttings disposal protocols.

3. Long-term legal liability.

The disadvantages of OBM and SBM drilling fluids have led to a much safer and cheaper approach. HPWBMs (high performance water-based muds) have been developed over time. By adding shale inhibitors, stabilizers and lubricants, the gap in performance between OBM and WBM drilling fluids became smaller. These additives can decrease or retard shale from interacting with the water in the drilling fluid and provide wellbore stability (Arvind, et al. 2007). 


\section{Mud Inhibitors:}

Mud additives are commonly considered as drilling mud contaminants. Salt and calcium sulfate are called inhibitors when purposely added to drilling muds in order to prevent or retard the hydration of clay in shale formations .There are many additives, traditionally salts such potassium chloride $(\mathrm{KCl})$ that can be used to decrease water activity in the mud. The salt in the drilling fluid dissolves into ions; anions which are negatively charged and cation which are positively charged. The negatively charged clay platelets in the shale attract the positively charged cation in the mud in a process called "cation exchange." After this process takes place, the clay platelets reach electrical charge equilibrium eliminating the need to attract the much larger and less charged water molecules to reach such state.

$$
\mathrm{KCl}+\mathrm{H}_{2} \mathrm{O}=\mathrm{K}^{+}+\mathrm{Cl}^{-}
$$

The challenge remains of what additives to use and in what concentration. This is because no two shales are alike. Different shales have different clay minerals with different concentrations and different matrix structures. Thus, a mud that is suited for Barnett shale might not be suitable for Marcellus shale and vice versa. 


\section{Aluminum Chemistry:}

The Marcellus shale has high concentration of illite clay, which is prone to dispersion. The illite makes up anywhere from $20 \%$ to $80 \%$, making Marcellus shale very fragile and dispersive. Also, the presence of calcite and kaolinite makes the Marcellus prone to swelling. Figure 22 shows the mineral composition of a Marcellus shale sample from Pennsylvania. The mineralogy of the sample was obtained using X-ray Diffraction technique (XRD). It shows that illite makes up for $24.6 \%, 0.3 \%$ calcite, and $2.6 \%$ kaolinite of the shale. Though this was a sample from Pennsylvania, it should give a good indication of the Marcellus in West Virginia due to close geographical proximity of the two states.

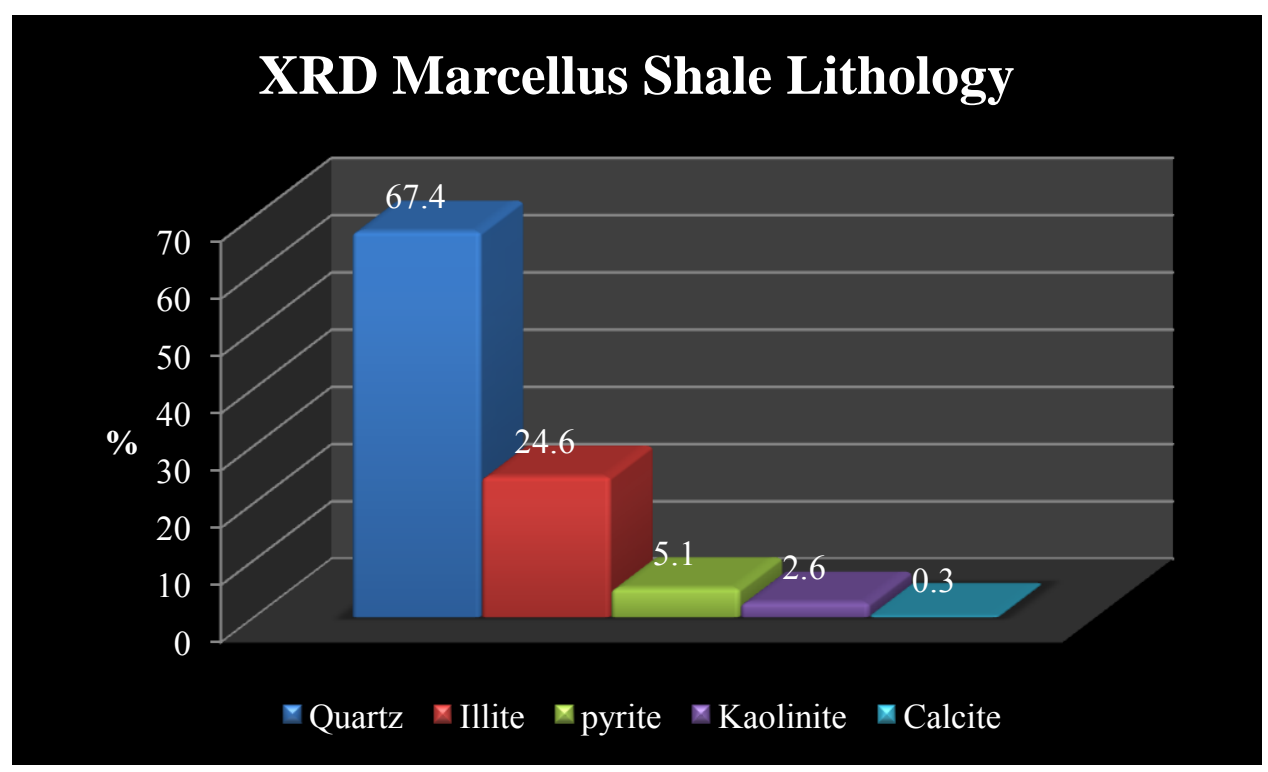

Figure 22: Marcellus Shale X-ray Diffraction (Boyce and Carr 2009)

Traditional mud inhibitors that depend only on cation exchange, can minimize swelling, but can't prevent borehole stability problems. The cation exchange approach gives the charge equilibrium for the clay and preventing it from swelling, but leaves the pores open. This leaves the shale pores prone to the hydrostatic pressure from the mud column. As a result, pore pressure around the wellbore will be elevated with nowhere to dissipate this pressure due to low 
permeability of the shale. This stress will fracture and break the shale front. Pore pressure transmission problem becomes more serious in high illite shale such as the Marcellus.

The application of aluminum salts as shale stabilizers in drilling fluids was first described in 1973. However, the mechanism of their ability to do so wasn't fully understood at time. The development of pore pressure transmission in shale has lead to the identification of aluminum salts shale inhabitation mechanisms.

The aluminum chemistry approach to shale stability is based on altering the shale matrix, in contrast to the widely used ion exchange approach. When aluminum salt is added to drilling mud systems, it produces aluminate, $\mathrm{Al}(\mathrm{OH})_{4}-$. The aluminate will remain soluble as long as the $\mathrm{pH}$ is maintained at 10 or higher. As filtrate from the mud encounters near wellbore pore space fluids at lower $\mathrm{pH}$, the soluble aluminate starts to precipitate as aluminum hydroxide, $\mathrm{Al}(\mathrm{OH})_{3}$. Aluminum hydroxide precipitation in the pore spaces at the surface of the shale will create an inner mud cake. This inner mud cake will significantly reduce pore pressure transmission and provide extra support to the shale.

In this study, potassium alum was used as a source of aluminum hydroxide. Potassium alum is the potassium double sulfate of aluminum and its chemical formula is $\mathrm{KAl}\left(\mathrm{SO}_{4}\right)_{2}$. It is commonly found in its dodecahydrate form as $\mathrm{KAl}\left(\mathrm{SO}_{4}\right)_{2} \cdot 12\left(\mathrm{H}_{2} \mathrm{O}\right)$. It occurs naturally as a sulfate mineral, usually on rocks in areas of weathering and oxidation of sulfide minerals and potassium bearing minerals. It is commonly used in water purification, body deodorants, after shaving products, stop-bleeding and cosmetic products and in medicine.

$$
\begin{gathered}
\mathrm{KAl}\left(\mathrm{SO}_{2}\right)_{2} \cdot 12 \mathrm{H}_{2} \mathrm{O} \rightarrow \mathrm{K}^{+}(\mathrm{aq})+\mathrm{Al}(\mathrm{OH})_{3}(\mathrm{~s})+2 \mathrm{SO}_{4}^{-}(\mathrm{aq})+6 \mathrm{H}_{2} \mathrm{O}(\mathrm{l}) \\
\mathrm{Al}(\mathrm{OH})_{3}(\mathrm{~s}) \rightarrow^{\text {water }} \mathrm{pH} \geq 10 \mathrm{Al}(\mathrm{OH})_{4}^{-}(\mathrm{aq})
\end{gathered}
$$


This aluminum was chosen based on three main factors:

A. Safe to handle and environmentally acceptable.

B. Available in commercial quantities with acceptable prices ( $\$ 31.50 / 50 \mathrm{lb}$ sack) (Gallade Chemical 2012).

C. Unlike other aluminum salts, it produces potassium ion; instead of adding potassium chloride $\mathrm{KCl}$ to the mud later to increase its inhabitation performance and eliminating the chlorine byproduct as well.

Also Soda Ash, Sodium carbonate $\mathrm{Na}_{2} \mathrm{CO}_{3}$, was used in the mud as a $\mathrm{pH}$ regulator to maintain stable alkaline conditions for the aluminate to remain soluble in the mud. It is commonly added in pools to neutralize the acidic effects of chlorine and raise $\mathrm{pH}$. 


\section{Previous Work}

Few published work related to aluminum/precipitating chemistry in drilling fluids, since pore pressure transmission measuring techniques have been only developed recently (Stowe, et al. 2001) . Nonetheless, the aluminum chemistry in drilling fluids has been applied in Louisiana USA, Gulf of Mexico, South America, Norway, and Algeria (Halliday, et al. 1993) (Ramirez, et al. 2005).

M. Ramirez, D. Clapper, P. Kenny published their work on the same subject in 2005. Their work was focused on developing a water based mud to be used in exploration wells in a very environmental sensitive area in the Upper Magdalena Valley of Colombia. The targeted formation was the Villeta shale, which was associated with major well stability and stuck-pipe issues. Shale cuttings from a nearby well were taken to perform test on them with the aluminum inhibitor mud.

Hydration and pore-pressure transmission tests were performed on the samples with different drilling fluids. Their studies showed that the use of aluminum complex in water resulted in $12 \%$ hydration, whereas it was $50 \%$ in fresh water. The mud was put to use in several wells and no bit balling or stability problems were encountered and the mud was deemed successful. (M., D. and G., et al. 2005)

The same group of researchers also published their second case study in 2006. This study was conducted on the Napo shale of Yuralpa Field, Ecuador. Wellbore stability was the major drilling problem in this field. Moreover, there were environmental concerns of using oil based mud. Their work lead to the use of water based mud (Barite) incorporated with Aluminum salt as an inhibitor and a stabilizer. (Ramirez, et al. 2006) 
They conducted dispersion tests on the Napo shale, which showed $58.2 \%$ dispersion in fresh water, $38.2 \%$ dispersion in xanthan gum mud and $14.2 \%$ in the aluminum inhibitor mud. Their mud design yielded great results as the stability problems were eliminated and achieved higher penetration rates compared to traditional $\mathrm{KCl}$ muds.

In both published case studies, the name of the aluminum salt used was not disclosed. Both publications referred to it as AHC (Aluminum Hydroxide Complex) source. However, they stated the concentration of it in their design. The concentration of aluminum hydroxide complex source used was ranging from $1 \mathrm{lb} / \mathrm{bbl}$ in the Villeta shale and 3.5 for the Napo shale. Also, they added $5 \mathrm{lb} / \mathrm{bbl} \mathrm{KCl}$ in their mud design to further enhance the inhabitation performance of the drilling fluid.

M. Ramirez and his team of researchers have enhanced the understanding of aluminum chemistry in drilling fluids and showed its applicability in the field. In this study their general concept is incorporated in developing an environmentally acceptable water based mud for the Marcellus shale. 


\section{Experiment Setup and Preparation}

\section{Core samples}

The core samples used in this study were obtained from a well drilled in West Virginia. The core was taken from a depth of $6025 \mathrm{ft}$ and it was well preserved in a tight plastic enclosure. The original core sample was cylindrical with a diameter of 2-in. and a height of 20 -in. It was cut into smaller sections with the same diameter and a height ranging from $\{2.5$ to 7$\} \mathrm{mm}$. The samples were dried in an oven at $70^{\circ} \mathrm{C}$ until weight was stabilized. The average moisture content of the samples was approximately $1 \%$.A total of 39 samples have been prepared. Figure 23 shows some of the samples in the core oven during the drying process.

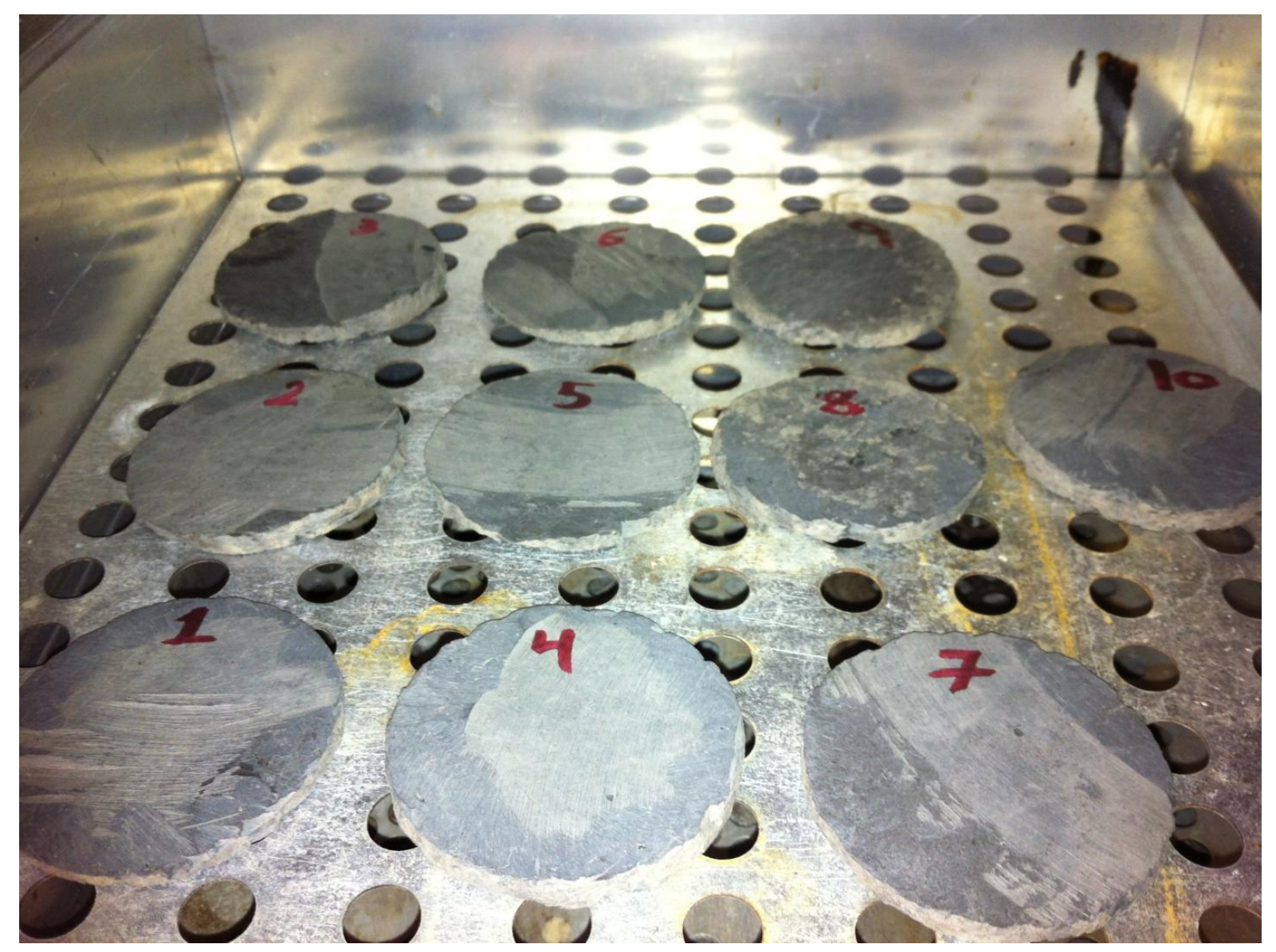

Figure 23: Core samples in the oven 


\section{Mud preparation}

To maintain consistency, the base mud was chosen to be $10 \mathrm{lb} / \mathrm{bbl}$ (pound per barrel) Aquagel clay, 2 lb/bbl Cellex polymer for filtration control, and $5 \mathrm{lb} / \mathrm{bbl}$ Soda Ash for $\mathrm{pH}$ control. The Potassium Alum was then added in different concentration to be tested with the shale samples. The fluids tested were:
A. Water: To provide a swelling baseline measure.
B. Base mud: To provide a reference point to compare the effect of the aluminum additive
C. Base mud $+0.5 \mathrm{lb} / \mathrm{bbl}$ Potassium Alum
D. Base mud $+0.75 \mathrm{lb} / \mathrm{bbl}$ Potassium Alum
E. Base mud $+1 \mathrm{lb} / \mathrm{bbl}$ Potassium Alum

The mud component properties are listed in Table 2:

\begin{tabular}{c|c|c|c|c|c|c}
\hline Component & Chemical Name & Chemical Formula & Application & Specific Gravity @ 20 C & $\mathrm{pH}$ & Recommended Concintration \\
\hline Aquagel & wyoming sodium bentonite & variable & Visocifier & 2.65 & $8--10(1 \%$ Solution $)$ & $0-25$ lbbbl \\
\hline Cellex & Carboxymethyl cellulose sodium & variable & Filltration Control & 1.6 & & $0.2-3.5 \mathrm{lb} / \mathrm{bbl}$ \\
\hline Soda Ash & Sodum Carbonate & $\mathrm{Na2CO} 3$ & $\mathrm{pH}$ Regulator & 2.5 & $11.3(1 \%$ Solution $)$ & $\mathrm{N} / \mathrm{A}$ \\
\hline Potssuim Alum & potassium double sulfate of aluminimum & $\mathrm{KAl}\left(\mathrm{SO}_{4}\right) 2$ & Mineral Salt & 1.757 & $3.0-3.5(10 \%$ aq.solution $)$ & $\mathrm{N} / \mathrm{A}$ \\
\hline
\end{tabular}

Table 2: Mud component Properties 


\section{Swelling Meter:}

To measure the swelling, three dial indicators with a $0.001 \mathrm{~mm}$ resolution were used. One of the three dial indicators was used as a dynamic swelling meter. The logic series indicators have a data output port. A smart cable with a customized module was used for data acquisition. The smart cable was programmed to acquire data from the dial indicator every six seconds. From one end it connects to the dial indicator via a RS-232 port and from the other to a computer via a normal USB port. The cable automatically inputs the data in a column in Microsoft ${ }^{\circledR}$ Excel. Therefore, the swelling versus time can be plotted to show the swelling profile of the samples.

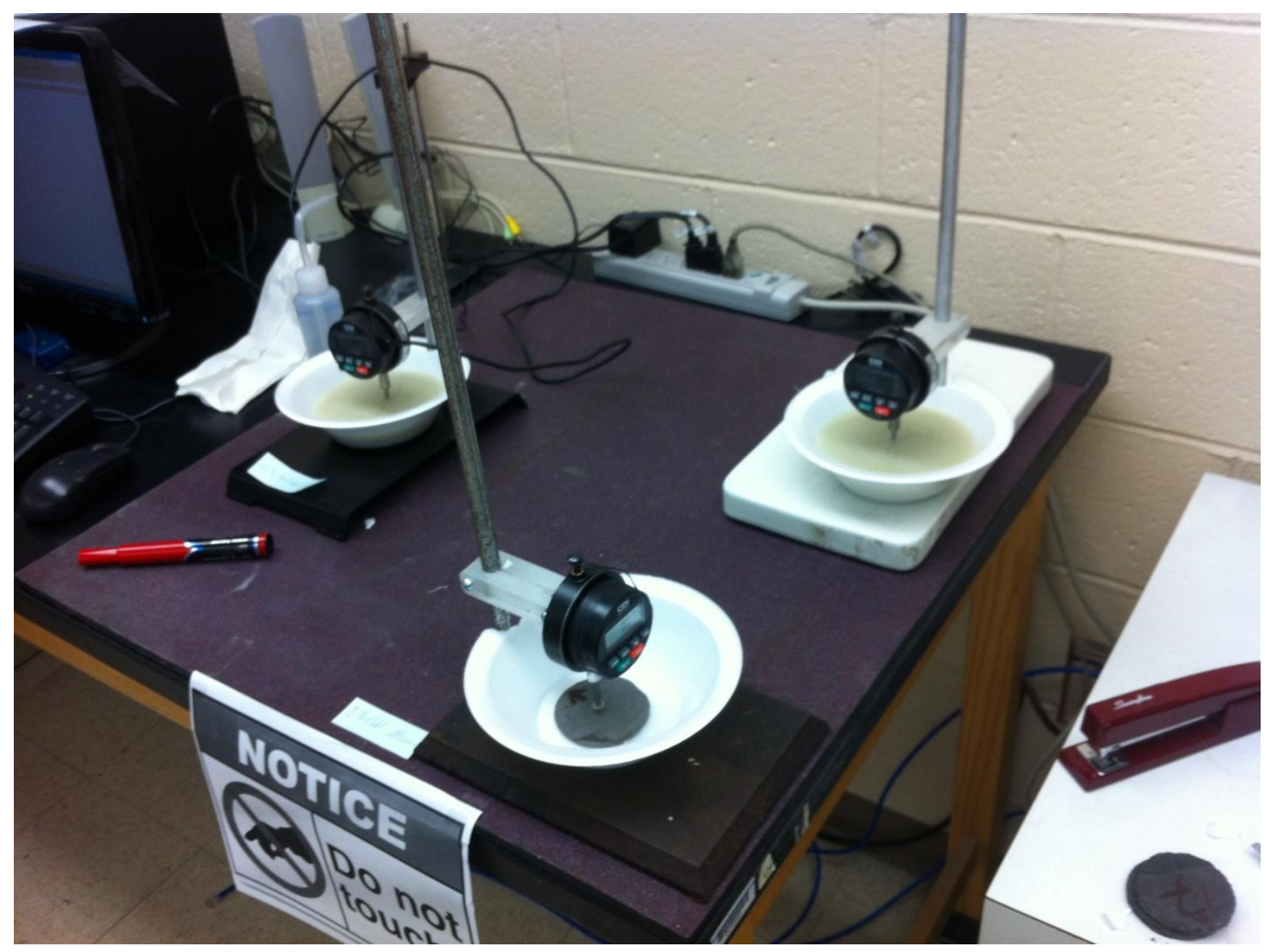

Figure 24: Swelling Meters 
Also, the contact point on each dial indicator was replaced with a wider flat one (Figure 25). This is to minimize the impact of the pen's weight by distributing it on a larger area. Though the weight is small, the swelling measurements are very sensitive.

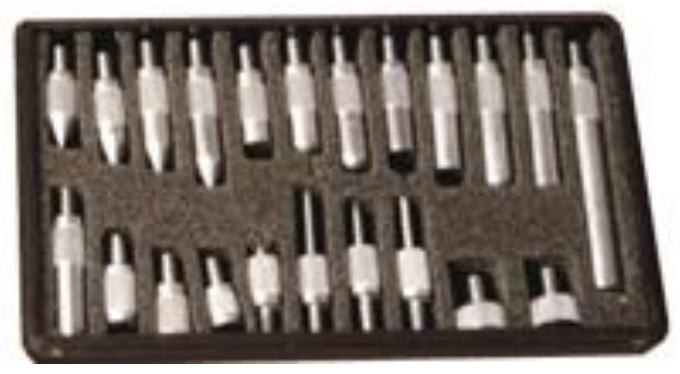

Figure 25: Dial Indicator contact points (http://www.auto-met.com)

Before testing the samples, their initial thickness is measured. To minimize measurement errors caused by surface irregularities of the shale samples, a point and arrow are marked on them (Figure 26). The sample is placed such that the arrow points towards the indicator's holding bar, while the marked point is where the initial thickness and swelling are measured. Also, for each swelling test, a fresh sample was used as they can't be reused due to the alteration of the shale matrix by the aluminum hydroxide precipitation.

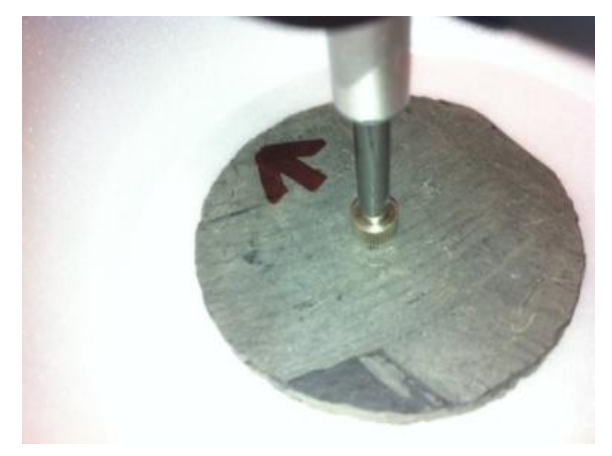

Figure 26: Core sample to be tested 


\section{Results and Discussion:}

\section{Swelling Test Results:}

\section{Water Baseline:}

This test was performed on samples 17,19 and 21 . The swelling test results were $4.88 \%$, $5.07 \%$, and $4.93 \%$ correspondingly. The average swelling was approximately $5 \%$, which is consistent with the little amount of swelling clay in the Marcellus shale showed by the X-ray Diffraction (Figure 22). The water baseline swelling results are shown in Table 3 and Figure 28.

\begin{tabular}{|c|c|c|c|}
\hline Sample \# & H Initial $(\mathrm{mm})$ & Swelling Height $(\mathrm{mm})$ & Swelling \% \\
\hline 17 & 3.302 & 0.161 & 4.88 \\
\hline 19 & 3.074 & 0.156 & 5.07 \\
\hline 21 & 3.427 & 0.169 & 4.93 \\
\hline Average & \multicolumn{3}{|c}{} \\
\cline { 2 - 4 } & & &
\end{tabular}

Table 3: Water Baseline Swelling Results

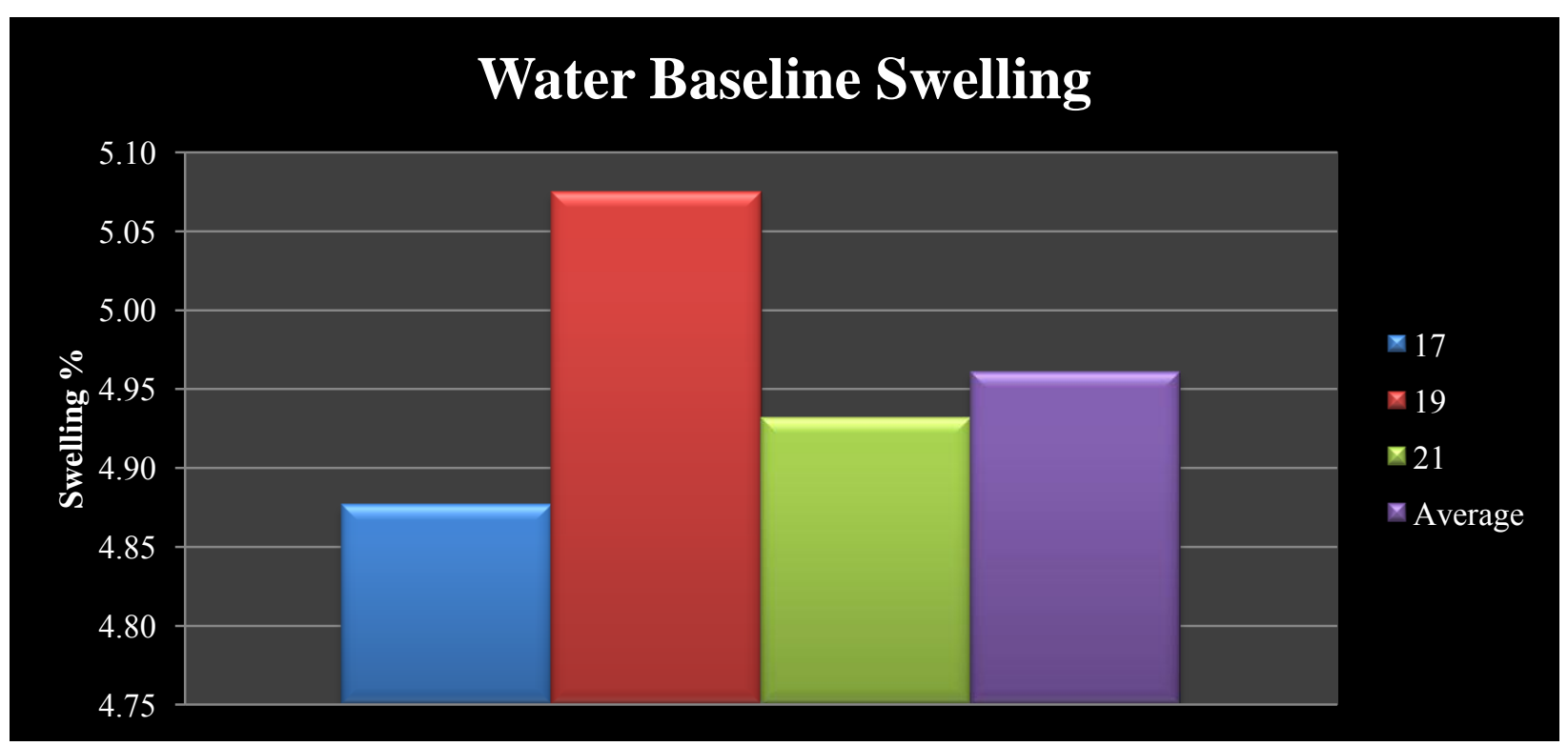

Figure 27: Water Baseline Swelling Summary 


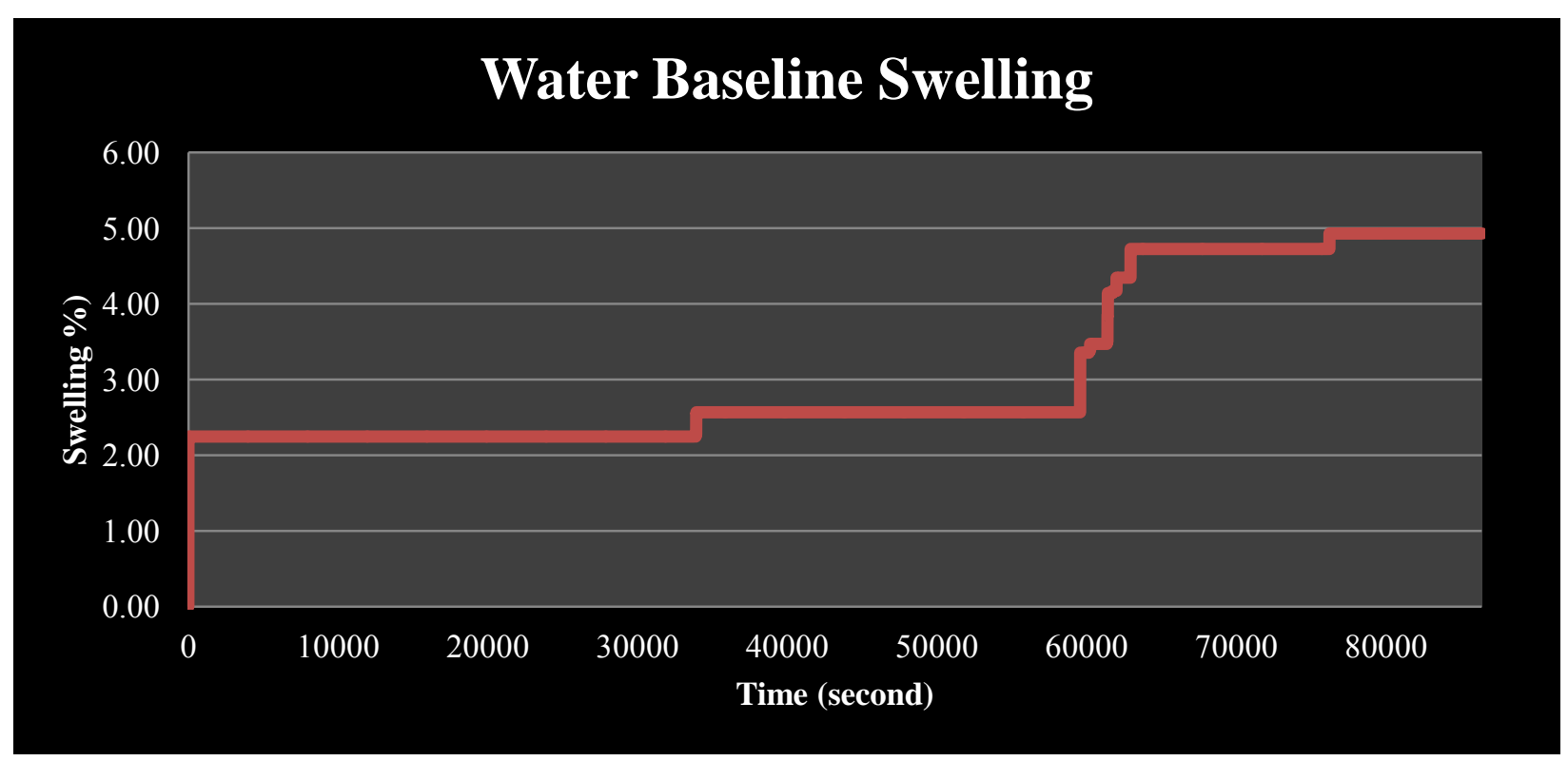

Figure 28: Dynamic Swelling Measrments (Water Baseline)

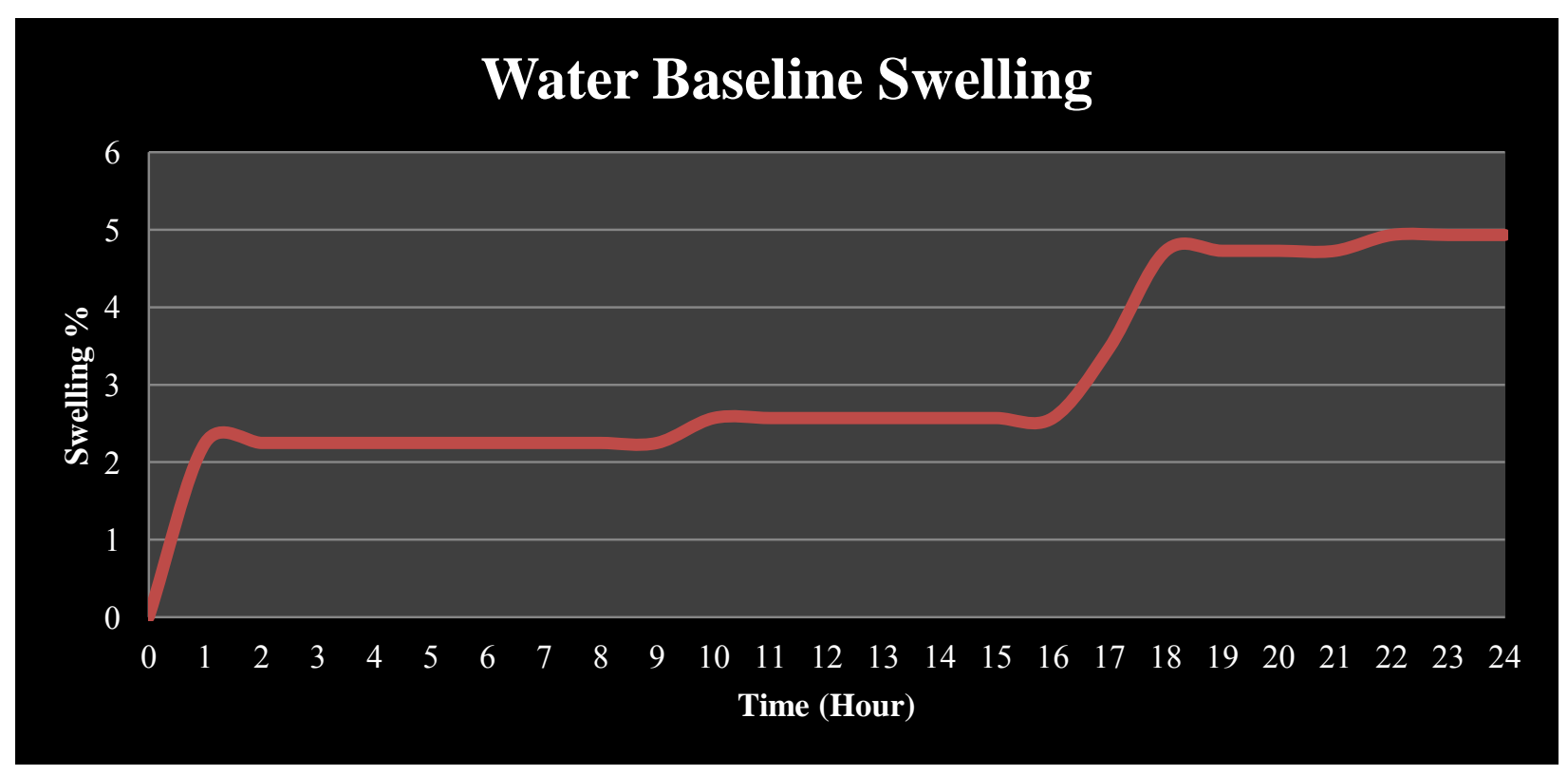

Figure 29: Dynamic Swelling Measrments (Water Baseline)

From Figures 28 and 29, swelling occurs instantaneously. Primary swelling is fast and stabilizes at around $2.5 \%$ within the first hour. Secondary swelling starts after 16 hours and violently jumps from $2.5 \%$ to around $5 \%$ in less than two hours. 


\section{Base Mud:}

This test was performed on samples 18, 12 and 14 with base mud. The components of the mud and their concentrations in $\mathrm{lb} / \mathrm{bbl}$ are shown in table 4 . The average swelling was almost $3 \%$. The Cellex polymer and Soda Ash had helped in reducing swelling by approximately $2 \%$. Table 5 and Figure 30 show the base mud swelling results.

\begin{tabular}{|c|c|}
\hline \multirow{2}{*}{ Component } & Concentration \\
\cline { 2 - 2 } & $\mathrm{lb} / \mathrm{bbl}$ \\
\hline Aquagel & 10 \\
\hline Cellex & 2 \\
\hline Soda Ash & 5 \\
\hline
\end{tabular}

Table 4: Base Mud Composition

\begin{tabular}{|c|c|c|c|}
\hline Sample \# & H Initial (mm) & Swelling Height $(\mathrm{mm})$ & Swelling \% \\
\hline 18 & 4.084 & 0.120 & 2.94 \\
\hline 12 & 3.607 & 0.109 & 3.02 \\
\hline 14 & 4.162 & 0.115 & 2.76 \\
\hline Average & & & 2.91 \\
\hline
\end{tabular}

Table 5: Base Mud Swelling Results

\section{Base Mud Swelling}

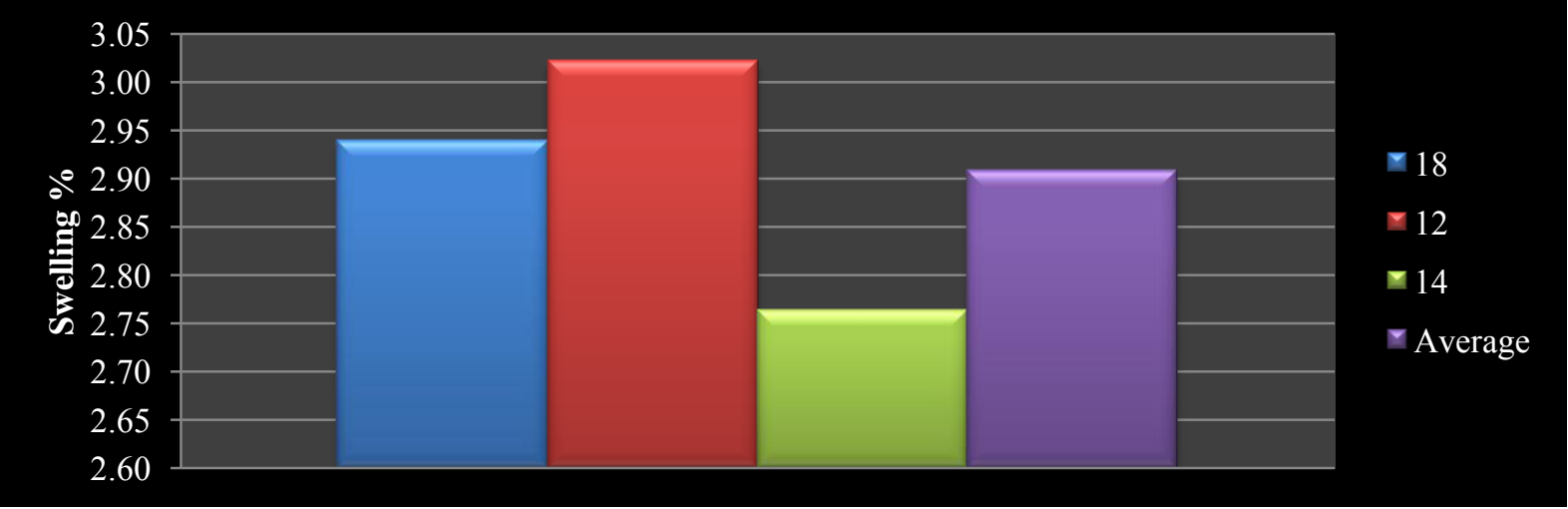

Figure 30: Base Mud Swelling Summary 


\section{Base Mud Swelling}

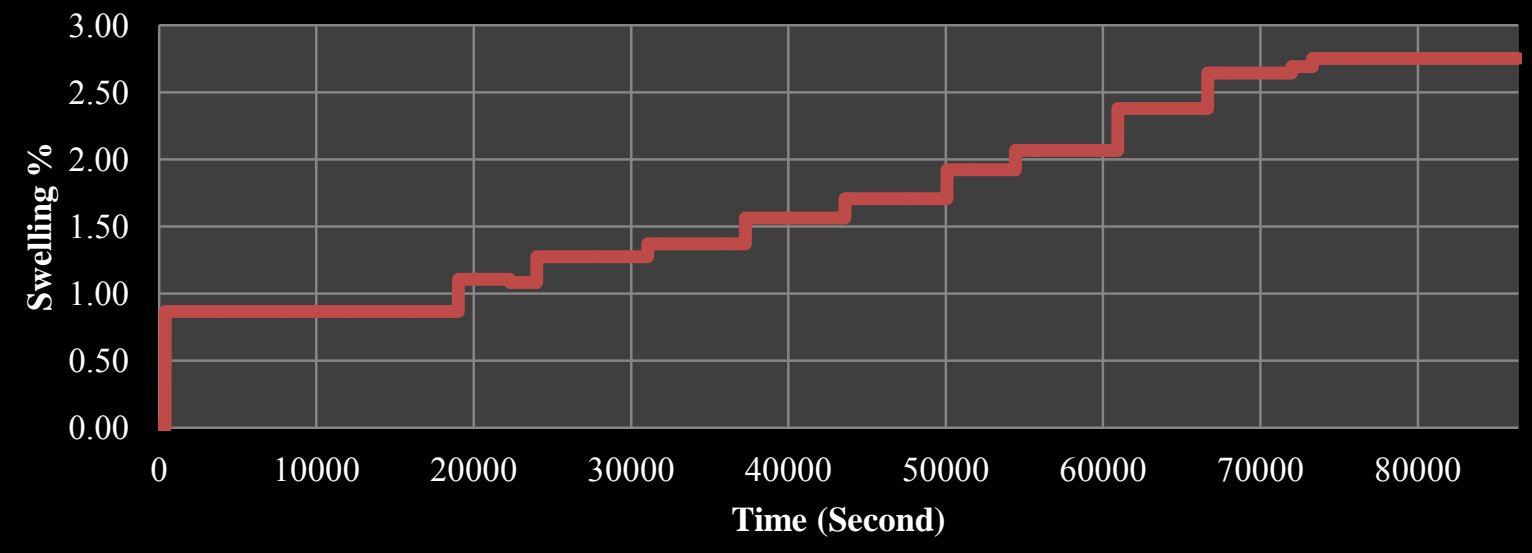

Figure 31: Dynamic Swelling Measrments (Base Mud)

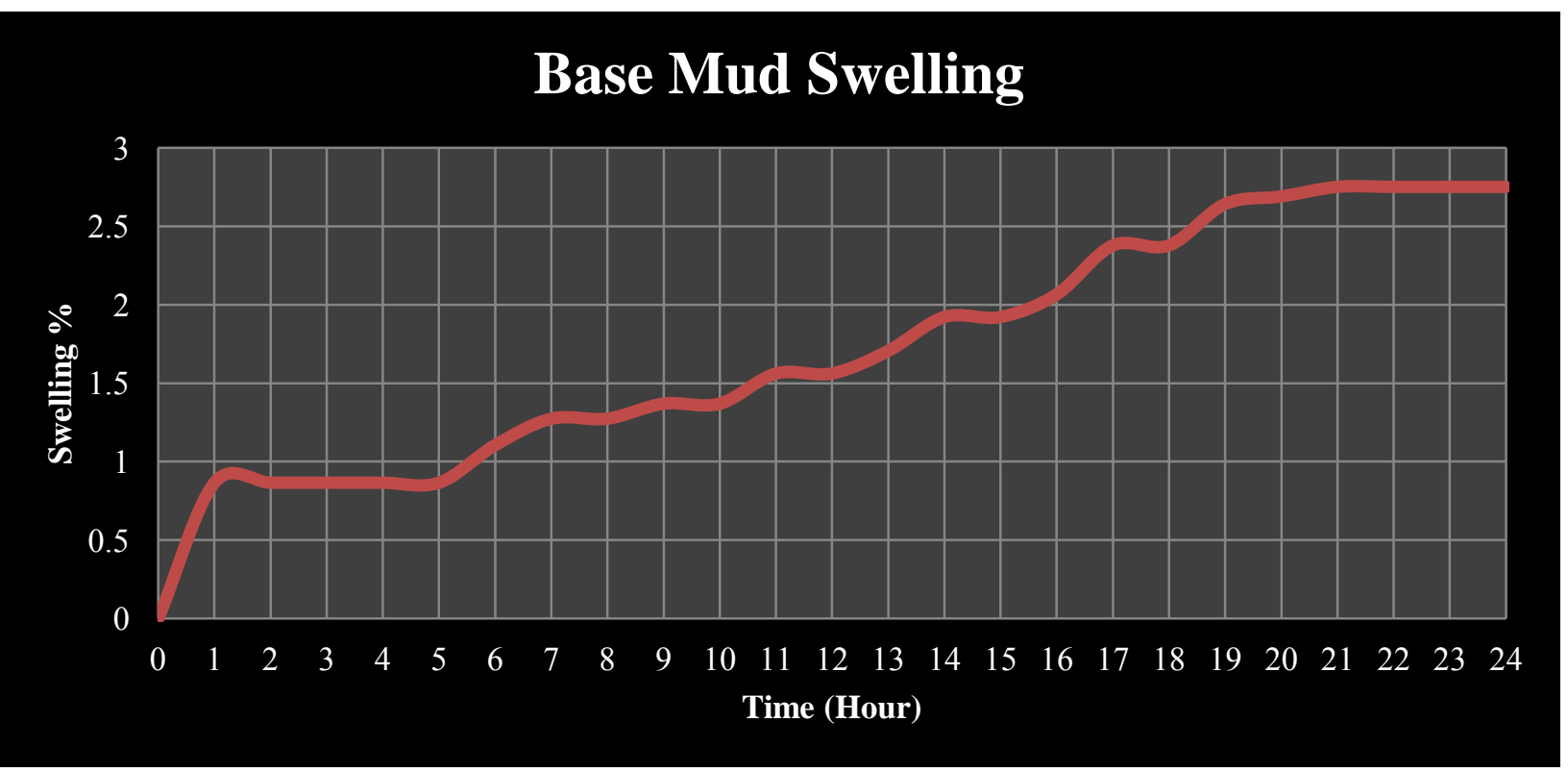

Figure 32: Dynamic Swelling Measrments (Base Mud)

Figures 31 and 32 show that primary swelling occurred instantaneously to reach $1 \%$. However, the swelling was slower and less aggressive than with water only. Additionally, Secondary swelling occurred after five hours only. The secondary swelling was slower and took around 15 hours to finally stabilize; increasing from $1 \%$ to $2.76 \%$. 


\section{Base Mud + 0.5 lb/bbl Potassium Alum:}

This test was performed on samples 15, 13 and 16. Table 6 shows the mud composition and concentrations in $\mathrm{lb} / \mathrm{bbl}$. This test mud was able to lower the swelling to an average of $\approx 1.41 \%$ (Table 7 and Figure33). The Marcellus shale showed high sensitivity to the potassium alum in the mud. The $0.5 \mathrm{lb} / \mathrm{bbl}$ potassium alum concentration in the mud was able to reduce the swelling by $1.59 \%$ from base mud which had an average of $3 \%$.

\begin{tabular}{|c|c|}
\hline \multirow{2}{*}{ Component } & Concentration \\
\cline { 2 - 2 } & $\mathrm{lb} / \mathrm{bbl}$ \\
\hline Aquagel & 10 \\
\hline Cellex & 2 \\
\hline Soda Ash & 5 \\
\hline Potassium Alum & 0.5 \\
\hline
\end{tabular}

Table 6: 0.5 lb/bbl Potassium Alum Mud Composition

\begin{tabular}{|c|c|c|c|}
\hline Sample \# & H Initial $(\mathrm{mm})$ & Swelling Height(mm) & Swelling \% \\
\hline 15 & 5.574 & 0.079 & 1.42 \\
\hline 13 & 6.99 & 0.098 & 1.40 \\
\hline 16 & 6.652 & 0.093 & 1.40 \\
\hline Average & \multicolumn{3}{|}{} \\
\cline { 2 - 4 } & & &
\end{tabular}

Table 7: (0.5 lb/bbl Potassium Alum) Mud Swelling Results

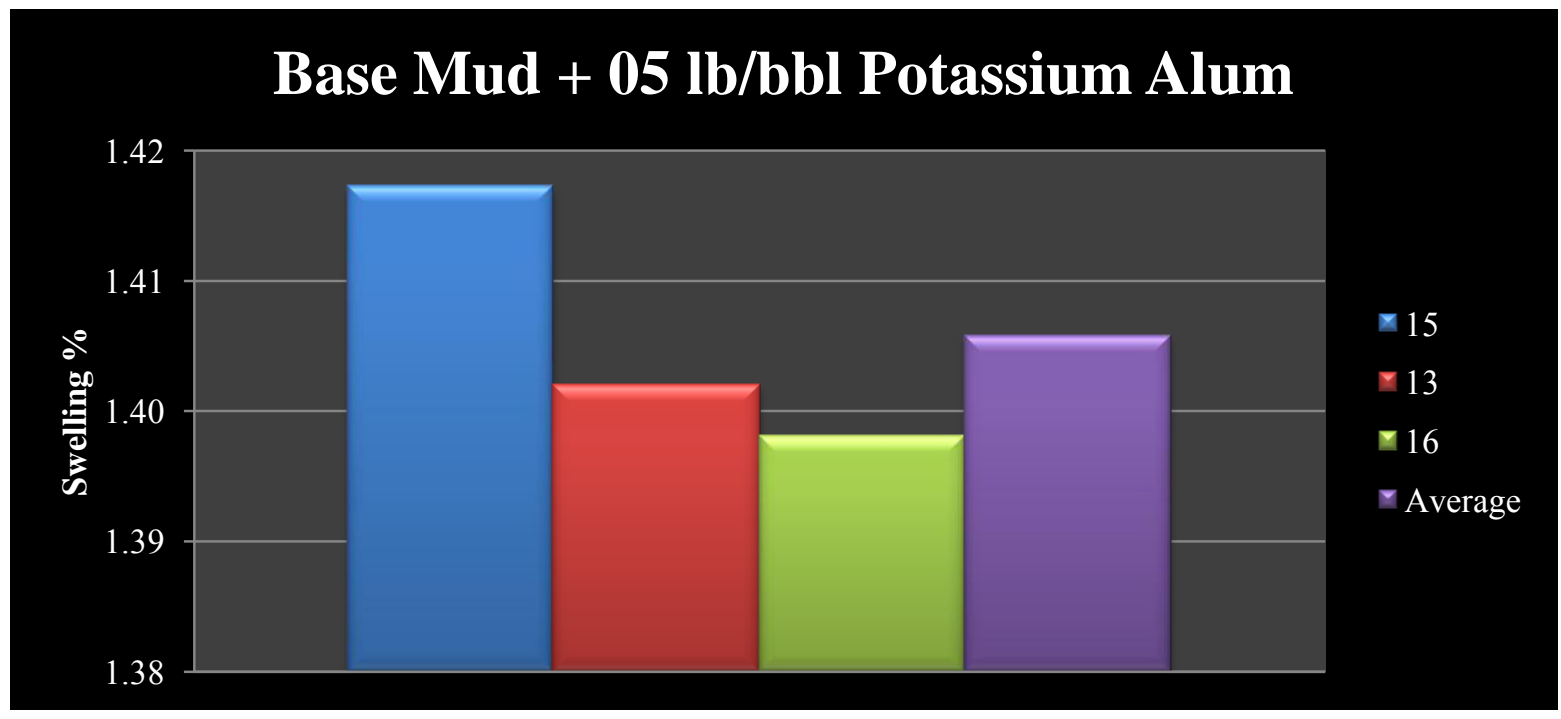

Figure 33: (0.5 lb/bbl Potassium Alum) Mud Swelling Summary 


\section{Base Mud + 05 lb/bbl Potassium Alum}

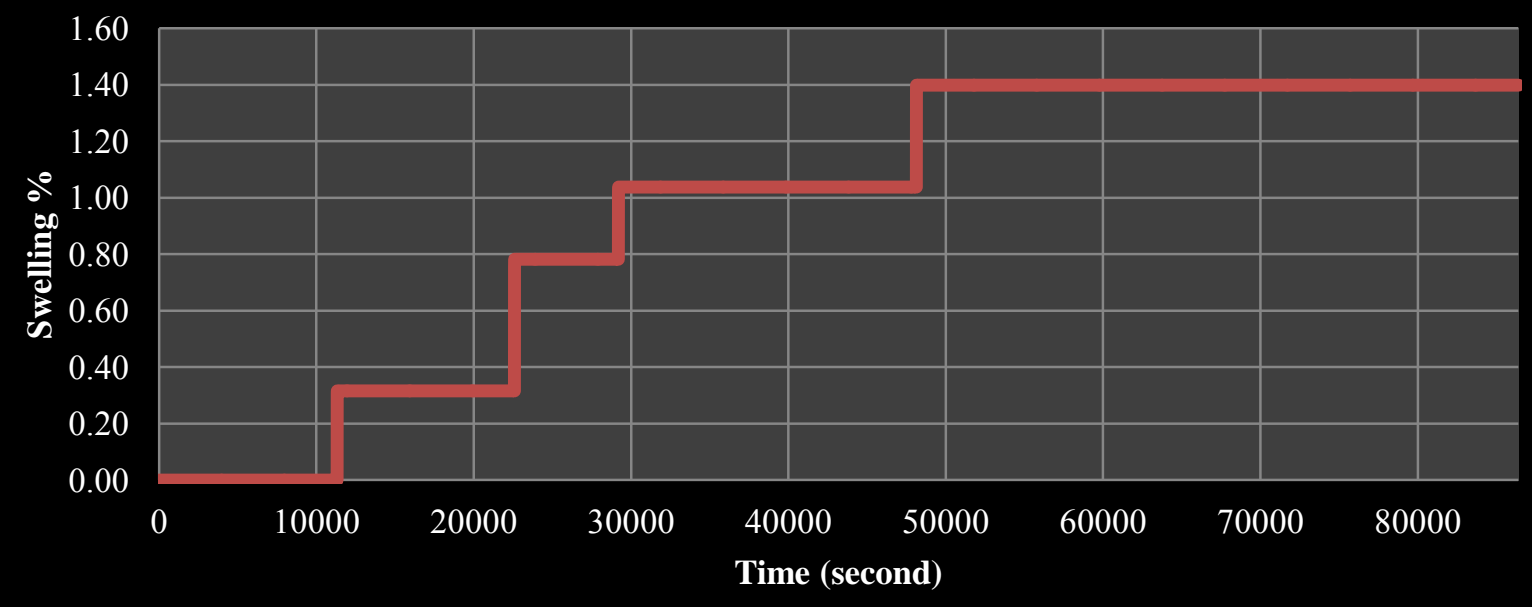

Figure 34: Dynamic Swelling Measrments (0.5 lb/bbl Potassium Alum) Mud

\section{Base Mud + 05 lb/bbl Potassium Alum}

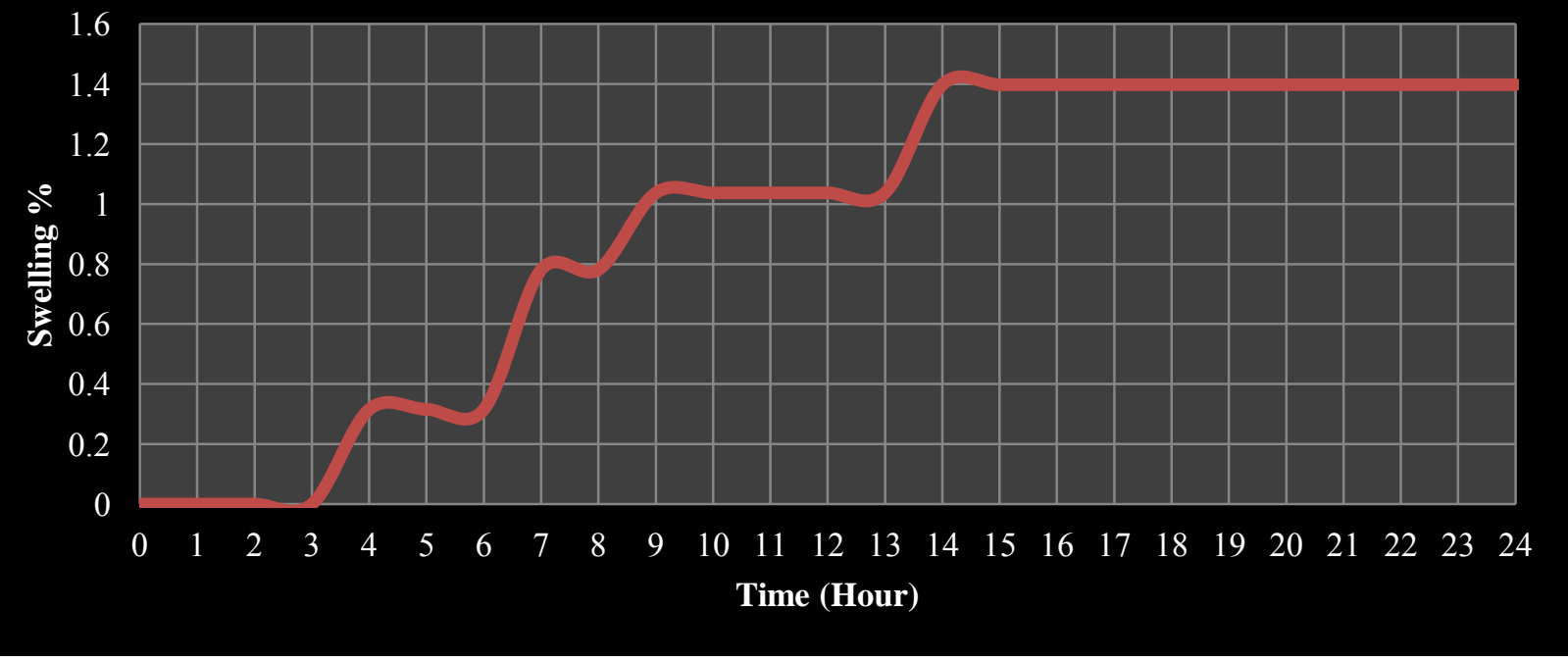

Figure 35: Dynamic Swelling Measrments (0.5 lb/bbl Potassium Alum) Mud

The dynamic swelling meter result showed that the $0.5 \mathrm{lb} / \mathrm{bbl}$ potassium alum mud was able to hold the sample from swelling for 3 hours (Figures 34 and 35). The swelling completely stabilized after 14 hours. The whole swelling process with this mud was only about 11 hours. The swelling process was shorter than its counterpart with water or base mud. 


\section{Base Mud + 1 lb/bbl Potassium Alum:}

This test was performed on samples number 11, 23 and 28. Table 8 shows the mud composition and concentrations in $\mathrm{lb} / \mathrm{bbl}$. The $1 \mathrm{lb} / \mathrm{bbl}$ potassium alum mud was able to completely suppress swelling (table 8). Also, the dynamic swelling test showed that there was no fluctuation during the whole 24 hours test period (Figure 36). From these results, it was concluded that the potassium alum concentration would be more than $5 \mathrm{lb} / \mathrm{bbl}$ and less or equal to $1 \mathrm{lb} / \mathrm{bbl}$. More tests were performed between these two concentrations to make sure that no more that required potassium alum is used in the mud. Table 9 shows the swelling test results for each sample.

\begin{tabular}{|c|c|}
\hline \multirow{2}{*}{ Component } & Concentration \\
\cline { 2 - 2 } & $\mathrm{lb} / \mathrm{bbl}$ \\
\hline Aquagel & 10 \\
\hline Cellex & 2 \\
\hline Soda Ash & 5 \\
\hline Potassium Alum & 1 \\
\hline
\end{tabular}

Table 8: 1 lb/bbl Potassium Alum Mud Composition

\begin{tabular}{|c|c|c|c|}
\hline Sample \# & H Initial (mm) & Swelling Height(mm) & Swelling \% \\
\hline 11 & 7.128 & 0 & 0.00 \\
\hline 23 & 5.66 & 0 & 0.00 \\
\hline 28 & 6.107 & 0 & 0.00 \\
\hline Average & \multicolumn{3}{|c}{0.00} \\
\cline { 3 - 4 } & Table 9: (1 lb/bbl Potassium Alum) Mud Swelling Results \\
\cline { 3 - 4 }
\end{tabular}

\section{Base Mud + 1 lb/bbl Potassium Alum}

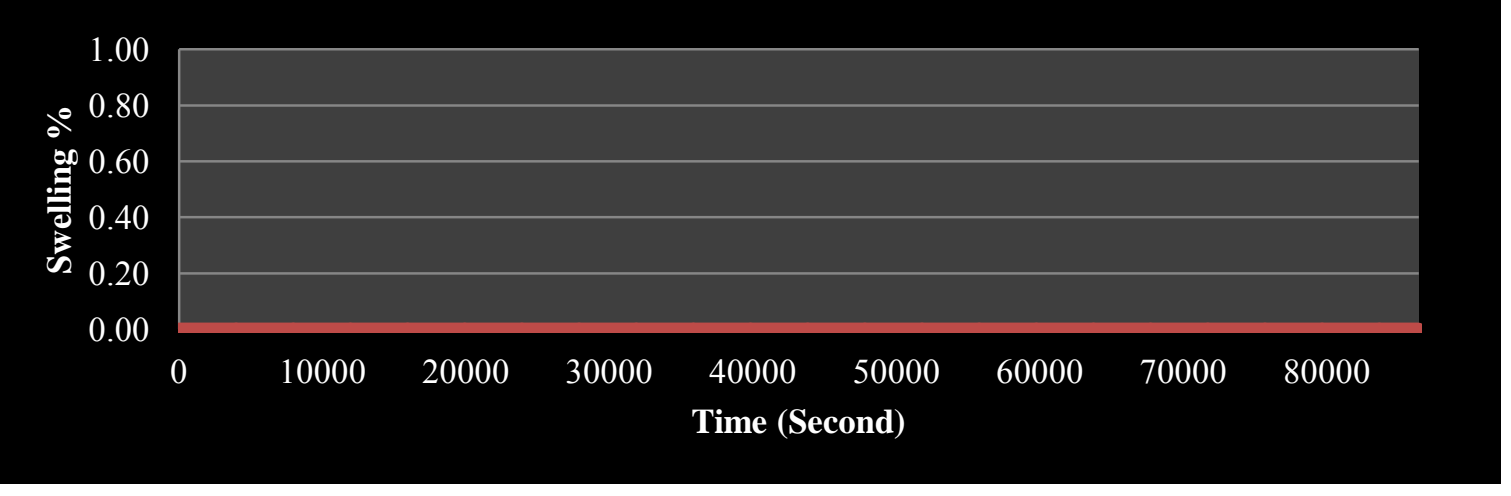

Figure 36: Dynamic Swelling Measrments (1 lb/bbl Potassium Alum )Mud 


\section{Base Mud + 0.6 lb/bbl Potassium Alum:}

Samples 3, 5 and 8 were tested with the $0.6 \mathrm{lb} / \mathrm{bbl}$ potassium alum mud. In this test, the average swelling was $1.24 \%$ (Table 10 and Figure 37 ). This mud was able to slightly reduce the swelling of the samples by an average of $0.17 \%$ compared to the $0.5 \mathrm{lb} / \mathrm{bbl}$ potassium alum mud. Nonetheless, this result was expected as the concentration of potassium alum was only $0.1 \mathrm{lb} / \mathrm{bbl}$ more.

\begin{tabular}{|c|c|}
\hline \multirow{2}{*}{ Component } & Concentration \\
\cline { 2 - 2 } & $\mathrm{lb} / \mathrm{bbl}$ \\
\hline Aquagel & 10 \\
\hline Cellex & 2 \\
\hline Soda Ash & 5 \\
\hline Potassium Alum & 0.6 \\
\hline
\end{tabular}

Table 10: 0.6 lb/bbl Potassium Alum Mud Composition

\begin{tabular}{|c|c|c|c|}
\hline Sample \# & H Initial (mm) & Swelling Height(mm) & Swelling \% \\
\hline 3 & 5.619 & 0.070 & 1.25 \\
\hline 5 & 5.19 & 0.064 & 1.23 \\
\hline 8 & 5.764 & 0.072 & 1.25 \\
\hline Average & \multicolumn{3}{|c}{} \\
\cline { 3 - 4 } & \multicolumn{3}{|c}{ Table 11: 0.6 lb/bbl Potassium Alum Mud Swelling Summary }
\end{tabular}

\section{Base Mud + 0.6 lb/bbl Potassium Alum}

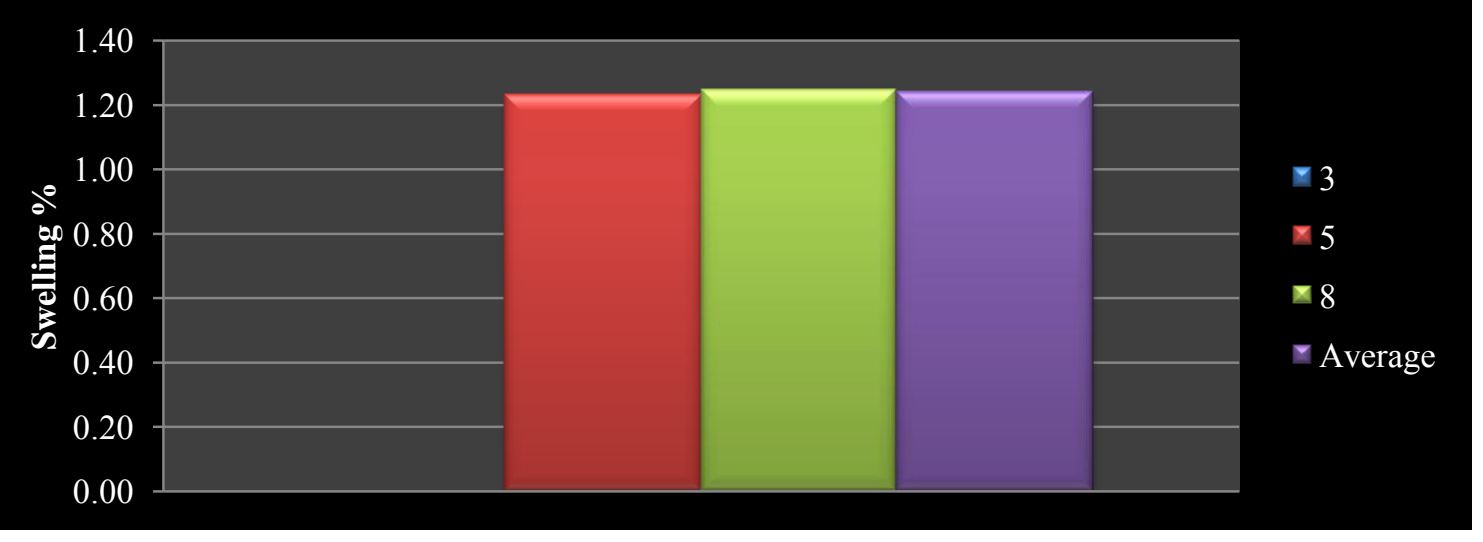

Figure 37: 0.6 lb/bbl Potassium Alum Mud Swelling Summary 


\section{Base Mud + 0.6 lb/bbl Potassium Alum}

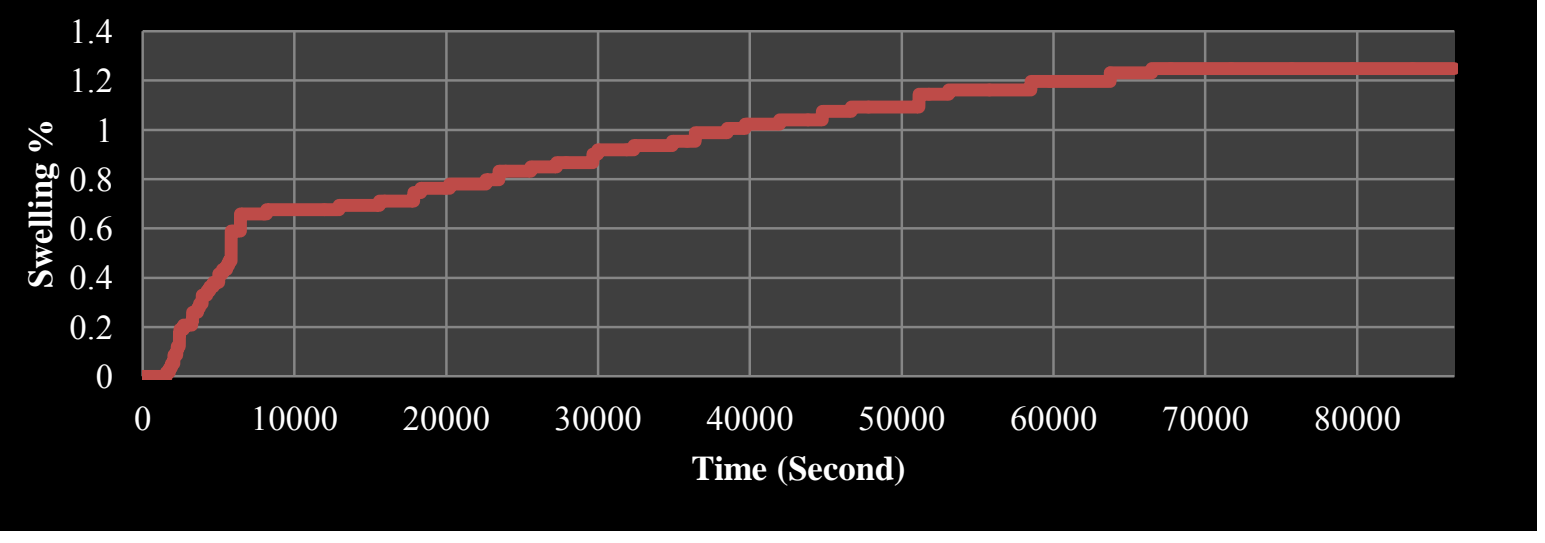

Figure 38: Dynamic Swelling Measrments (0.6 lb/bbl Potassium Alum) Mud

\section{Base Mud + 0.6 lb/bbl Potassium Alum}

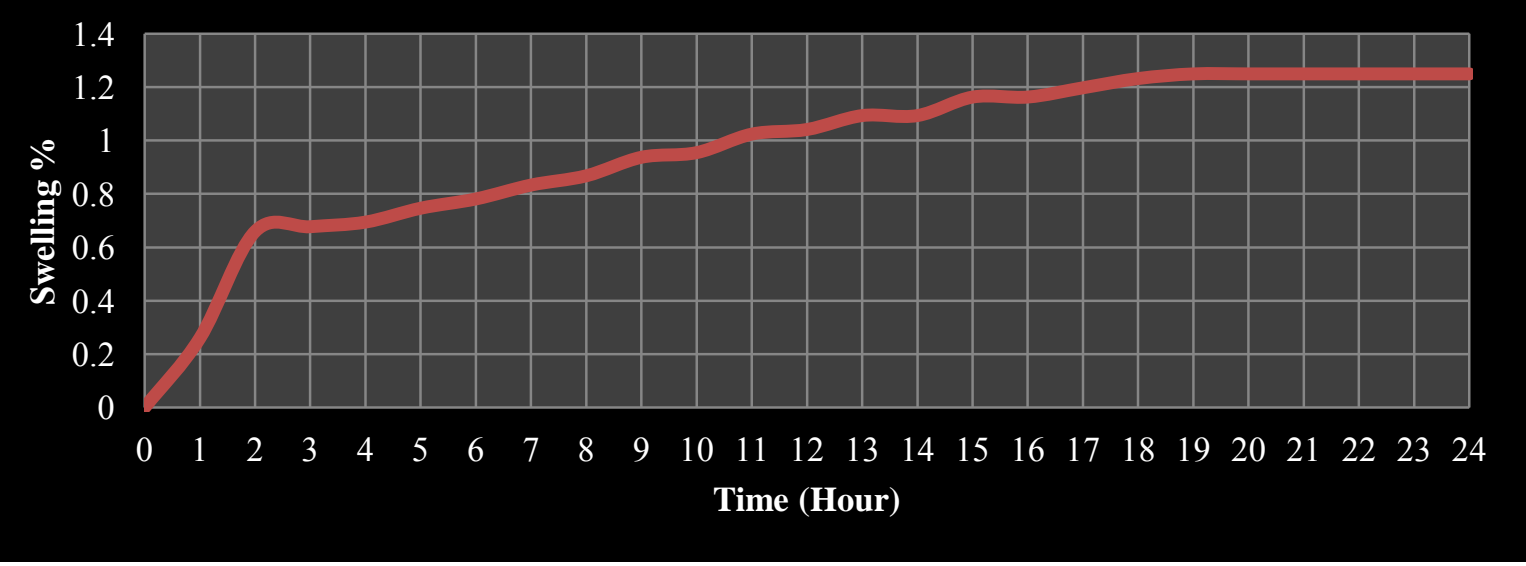

Figure 39: Dynamic Swelling Measrments (0.6 lb/bbl Potassium Alum) Mud

Figures 38 and 39 from the dynamic measurements showed a very different swelling profile than the $0.5 \mathrm{lb} / \mathrm{bbl}$ alum mud. The $0.6 \mathrm{lb} / \mathrm{bbl}$ alum mud was able to hold the swelling for only less than 10 minutes, whereas the $0.5 \mathrm{lb} / \mathrm{bbl}$ mud was able to do so for 3 hours. Also, the swelling process took a longer time to stabilize. The sample took 18 hours to stabilize and it was increasing almost linearly. The sensitivity of Marcellus shale was observed as the swelling profile completely changed with a small concentration increase of potassium alum. 


\section{Base Mud + 0.7 lb/bbl Potassium Alum:}

The $0.7 \mathrm{lb} / \mathrm{bbl}$ alum mud test was performed on samples number 2, 6 and 10 (Table 13). Table 12 shows the mud composition and concentrations in $\mathrm{lb} / \mathrm{bbl}$. Unexpectedly, the mud completely stoped the swelling in all samples. This was a drastic change from the earlier $0.6 \mathrm{lb} / \mathrm{bbl}$ alum mud, where it went down from an average of $1.24 \%$ to $0 \%$. This result provided that the 1 $\mathrm{lb} / \mathrm{bbl}$ potassium alum concentration in the mud was actually more than what it was needed to stop the swelling. The result was very surprising and it was decided to redo the test to re-confirm it. Figure 40 shows the dynamic swelling measrments performed on sample number 10, where it shows no fluctuations occurred during the test.

\begin{tabular}{|c|c|}
\hline \multirow{2}{*}{ Component } & $\begin{array}{c}\text { Concentration } \\
\mathrm{lb} / \mathrm{bbl}\end{array}$ \\
\hline Aquagel & 10 \\
\hline Cellex & 2 \\
\hline Soda Ash & 5 \\
\hline Potassium Alum & 0.7 \\
\hline
\end{tabular}

Table 12: $0.7 \mathrm{lb} / \mathrm{bbl}$ Potassium Alum Mud Composition

\begin{tabular}{|c|c|c|c|}
\hline Sample \# & H Initial $(\mathrm{mm})$ & Swelling Height(mm) & Swelling \% \\
\hline 2 & 4.815 & 0 & 0.00 \\
\hline 6 & 4.307 & 0 & 0.00 \\
\hline 10 & 5.024 & 0 & 0.00 \\
\hline Average & \multicolumn{3}{|}{} \\
\cline { 2 - 4 }
\end{tabular}

Table 13: $0.7 \mathrm{lb} / \mathrm{bbl}$ Potassium Alum Mud Swelling Summary

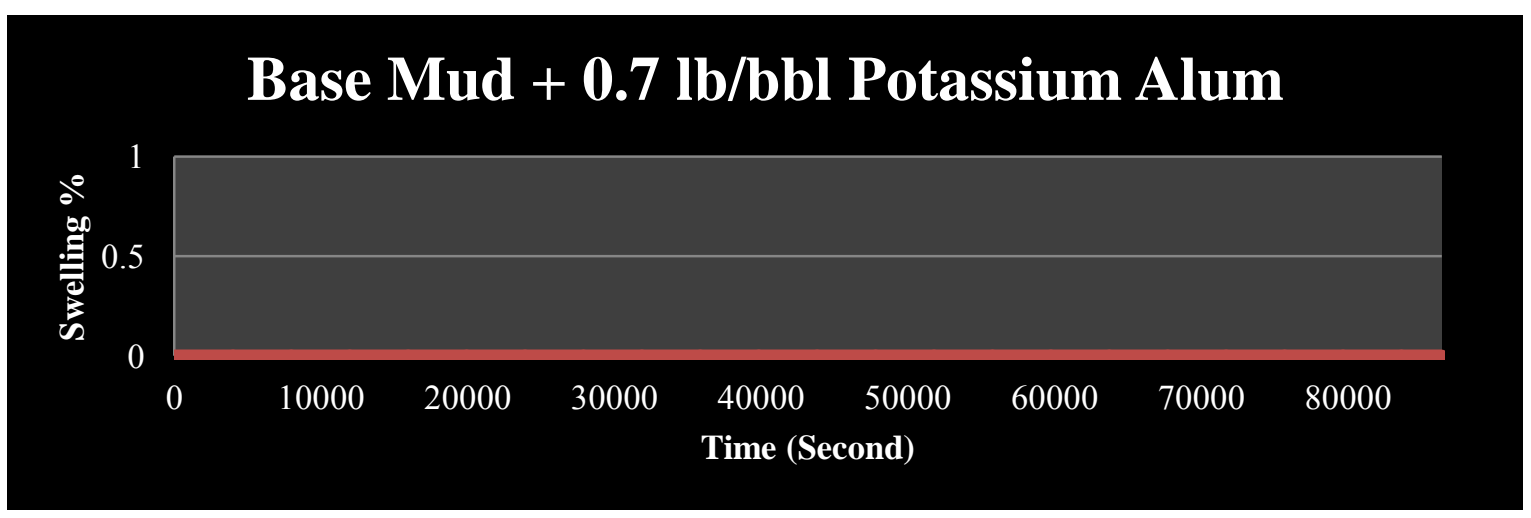

Figure 40: Dynamic Swelling Measrments (0.7 lb/bbl Potassium Alum) Mud I 


\section{Base Mud + 0.7 lb/bbl Potassium Alum (Re-Confirmation)}

The performance re-confirmation of the $0.7 \mathrm{lb} / \mathrm{bbl}$ potassium alum mud was performed on samples number 5, 1 and 7. The results shown in Table 14 were consistent with the earlier test, only one sample varied with a $0.001 \mathrm{~mm}(0.03 \%)$ making the average swelling of the whole test to be $0.01 \%$. As a result, it was decided that the $0.7 \mathrm{lb} / \mathrm{bbl}$ alum mud was the best performer and there was no need to increase the alum concentration. Figure 41 shows the dynamic swelling measrments in sedconds.

\begin{tabular}{|c|c|c|c|}
\hline Sample \# & H Initial $(\mathrm{mm})$ & Swelling Height $(\mathrm{mm})$ & Swelling \% \\
\hline 5 & 4.930 & 0 & 0.00 \\
\hline 1 & 3.705 & 0.001 & 0.03 \\
\hline 7 & 7.005 & 0 & 0.00 \\
\hline Average & \multicolumn{3}{|r}{} \\
\cline { 3 - 4 }
\end{tabular}

Table 14: 0.7 lb/bbl Potassium Alum Mud Swelling Summary II

\section{Base Mud + 0.7 lb/bbl Potassium Alum}

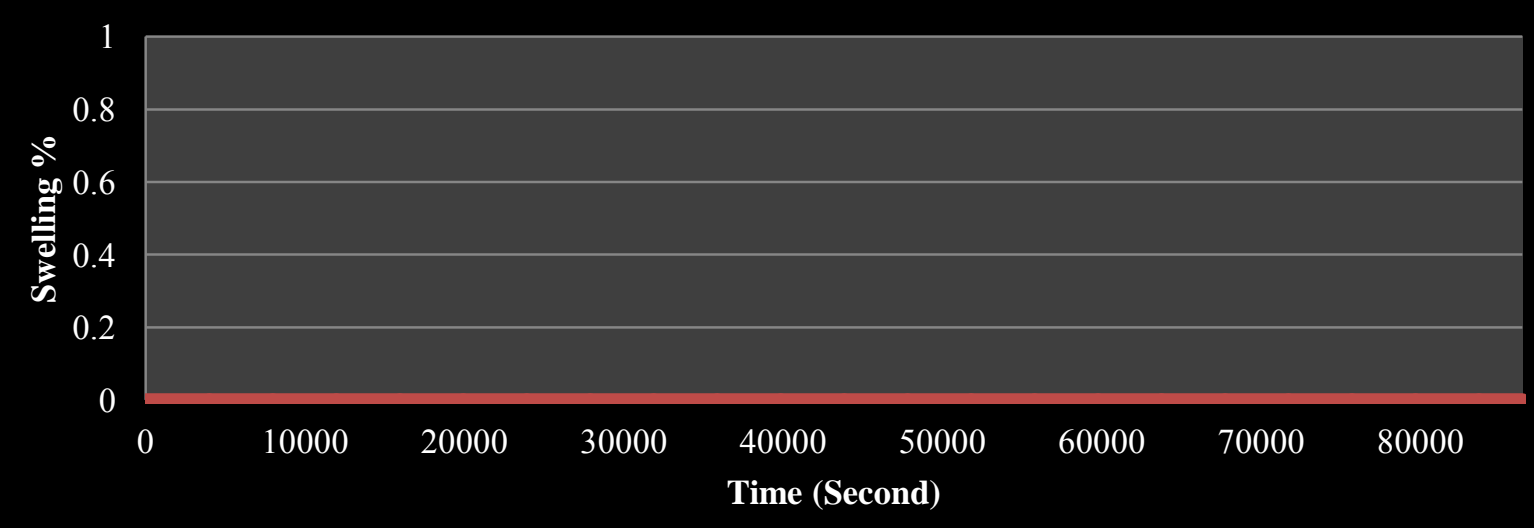

Figure 41: Dynamic Swelling Measrments (0.7 lb/bbl Potassium Alum) Mud II 
Swelling Test Results and Summary:

\begin{tabular}{|c|c|}
\hline \multicolumn{2}{|c|}{ Baseline (Water) } \\
\hline Time h & Swelling $\%$ \\
\hline 0 & 0.00 \\
\hline 1 & 2.25 \\
\hline 2 & 2.25 \\
\hline 3 & 2.25 \\
\hline 4 & 2.25 \\
\hline 5 & 2.25 \\
\hline 6 & 2.25 \\
\hline 7 & 2.25 \\
\hline 8 & 2.25 \\
\hline 9 & 2.25 \\
\hline 10 & 2.57 \\
\hline 11 & 2.57 \\
\hline 12 & 2.57 \\
\hline 13 & 2.57 \\
\hline 14 & 2.57 \\
\hline 15 & 2.57 \\
\hline 16 & 2.57 \\
\hline 17 & 3.47 \\
\hline 18 & 4.73 \\
\hline 19 & 4.73 \\
\hline 20 & 4.73 \\
\hline 21 & 4.73 \\
\hline 22 & 4.93 \\
\hline 23 & 4.93 \\
\hline 24 & 4.93 \\
\hline
\end{tabular}

\begin{tabular}{|c|c|}
\hline \multicolumn{2}{|c|}{ Base Mud } \\
\hline Time hr & Swelling $\%$ \\
\hline 0 & 0.00 \\
\hline 1 & 0.86 \\
\hline 2 & 0.86 \\
\hline 3 & 0.86 \\
\hline 4 & 0.86 \\
\hline 5 & 0.86 \\
\hline 6 & 1.11 \\
\hline 7 & 1.27 \\
\hline 8 & 1.27 \\
\hline 9 & 1.37 \\
\hline 10 & 1.37 \\
\hline 11 & 1.56 \\
\hline 12 & 1.56 \\
\hline 13 & 1.71 \\
\hline 14 & 1.92 \\
\hline 15 & 1.92 \\
\hline 16 & 2.07 \\
\hline 17 & 2.38 \\
\hline 18 & 2.38 \\
\hline 19 & 2.64 \\
\hline 20 & 2.69 \\
\hline 21 & 2.75 \\
\hline 22 & 2.75 \\
\hline 23 & 2.75 \\
\hline 24 & 2.75 \\
\hline
\end{tabular}

\begin{tabular}{|c|c|}
\hline \multicolumn{2}{|c|}{$0.5 \mathrm{lb} / \mathrm{bbl}$ Potassium Alum } \\
\hline Time hr & Swelling $\%$ \\
\hline 0 & 0.00 \\
\hline 1 & 0.00 \\
\hline 2 & 0.00 \\
\hline 3 & 0.00 \\
\hline 4 & 0.32 \\
\hline 5 & 0.32 \\
\hline 6 & 0.32 \\
\hline 7 & 0.78 \\
\hline 8 & 0.78 \\
\hline 9 & 1.04 \\
\hline 10 & 1.04 \\
\hline 11 & 1.04 \\
\hline 12 & 1.04 \\
\hline 13 & 1.04 \\
\hline 14 & 1.40 \\
\hline 15 & 1.40 \\
\hline 16 & 1.40 \\
\hline 17 & 1.40 \\
\hline 18 & 1.40 \\
\hline 19 & 1.40 \\
\hline 20 & 1.40 \\
\hline 21 & 1.40 \\
\hline 22 & 1.40 \\
\hline 23 & 1.40 \\
\hline 24 & 1.40 \\
\hline
\end{tabular}

\begin{tabular}{|c|c|}
\hline \multicolumn{2}{|c|}{$0.6 \mathrm{lb} / \mathrm{bbl}$ Potassium Alum } \\
\hline Time hr & Swelling $\%$ \\
\hline 0 & 0.00 \\
\hline 1 & 0.26 \\
\hline 2 & 0.66 \\
\hline 3 & 0.68 \\
\hline 4 & 0.69 \\
\hline 5 & 0.75 \\
\hline 6 & 0.78 \\
\hline 7 & 0.83 \\
\hline 8 & 0.87 \\
\hline 9 & 0.94 \\
\hline 10 & 0.95 \\
\hline 11 & 1.02 \\
\hline 12 & 1.04 \\
\hline 13 & 1.09 \\
\hline 14 & 1.09 \\
\hline 15 & 1.16 \\
\hline 16 & 1.16 \\
\hline 17 & 1.20 \\
\hline 18 & 1.23 \\
\hline 19 & 1.25 \\
\hline 20 & 1.25 \\
\hline 21 & 1.25 \\
\hline 22 & 1.25 \\
\hline 23 & 1.25 \\
\hline 24 & 1.25 \\
\hline
\end{tabular}

\begin{tabular}{|c|c|}
\hline \multicolumn{2}{|c|}{$1 \mathrm{lb} / \mathrm{bbl}$ Potassium Alum } \\
\hline Time hr & Swelling \% \\
\hline 0 & 0.00 \\
\hline 1 & 0.00 \\
\hline 2 & 0.00 \\
\hline 3 & 0.00 \\
\hline 4 & 0.00 \\
\hline 5 & 0.00 \\
\hline 6 & 0.00 \\
\hline 7 & 0.00 \\
\hline 8 & 0.00 \\
\hline 9 & 0.00 \\
\hline 10 & 0.00 \\
\hline 11 & 0.00 \\
\hline 12 & 0.00 \\
\hline 13 & 0.00 \\
\hline 14 & 0.00 \\
\hline 15 & 0.00 \\
\hline 16 & 0.00 \\
\hline 17 & 0.00 \\
\hline 18 & 0.00 \\
\hline 19 & 0.00 \\
\hline 20 & 0.00 \\
\hline 21 & 0.00 \\
\hline 22 & 0.00 \\
\hline 23 & 0.00 \\
\hline 24 & 0.00 \\
\hline
\end{tabular}

\begin{tabular}{|c|c|}
\hline \multicolumn{2}{|c|}{$0.7 \mathrm{lb} / \mathrm{bbl}$ Potassium Alum I } \\
\hline Time hr & Swelling \% \\
\hline 0 & 0.00 \\
\hline 1 & 0.00 \\
\hline 2 & 0.00 \\
\hline 3 & 0.00 \\
\hline 4 & 0.00 \\
\hline 5 & 0.00 \\
\hline 6 & 0.00 \\
\hline 7 & 0.00 \\
\hline 8 & 0.00 \\
\hline 9 & 0.00 \\
\hline 10 & 0.00 \\
\hline 11 & 0.00 \\
\hline 12 & 0.00 \\
\hline 13 & 0.00 \\
\hline 14 & 0.00 \\
\hline 15 & 0.00 \\
\hline 16 & 0.00 \\
\hline 17 & 0.00 \\
\hline 18 & 0.00 \\
\hline 19 & 0.00 \\
\hline 20 & 0.00 \\
\hline 21 & 0.00 \\
\hline 22 & 0.00 \\
\hline 23 & 0.00 \\
\hline 24 & 0.00 \\
\hline
\end{tabular}

\begin{tabular}{|c|c|}
\hline \multicolumn{2}{|c|}{$0.7 \mathrm{lb} / \mathrm{bbl}$ Potassium Alum II } \\
\hline Time hr & Swelling $\%$ \\
\hline 0 & 0.00 \\
\hline 1 & 0.00 \\
\hline 2 & 0.00 \\
\hline 3 & 0.00 \\
\hline 4 & 0.00 \\
\hline 5 & 0.00 \\
\hline 6 & 0.00 \\
\hline 7 & 0.00 \\
\hline 8 & 0.00 \\
\hline 9 & 0.00 \\
\hline 10 & 0.00 \\
\hline 11 & 0.00 \\
\hline 12 & 0.00 \\
\hline 13 & 0.00 \\
\hline 14 & 0.00 \\
\hline 15 & 0.00 \\
\hline 16 & 0.00 \\
\hline 17 & 0.00 \\
\hline 18 & 0.00 \\
\hline 19 & 0.00 \\
\hline 20 & 0.00 \\
\hline 21 & 0.00 \\
\hline 22 & 0.00 \\
\hline 23 & 0.00 \\
\hline 24 & 0.00 \\
\hline
\end{tabular}

Figure 42: Swelling Results Summary, One hour scale 


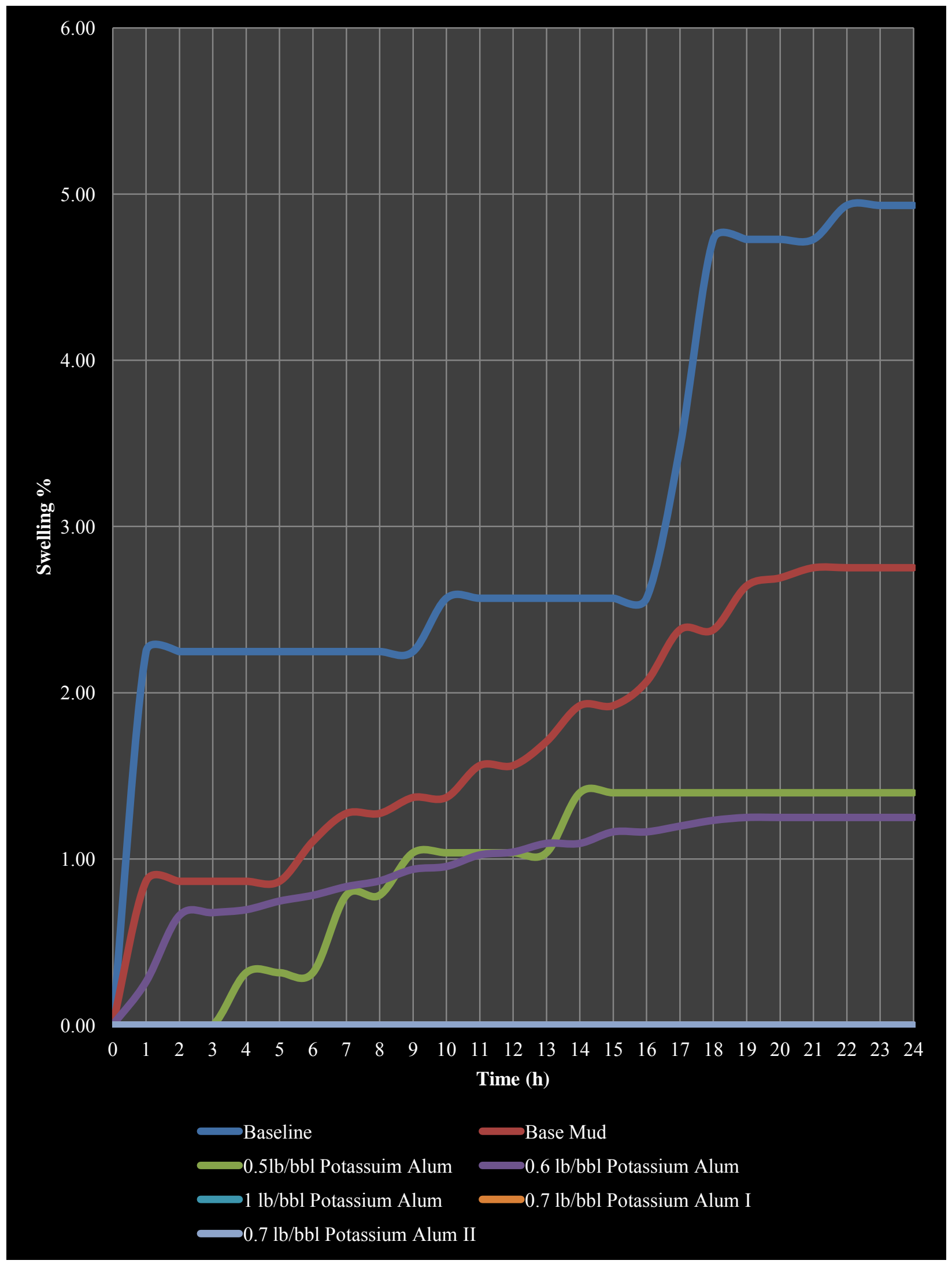

Figure 43: Comparison of Swelling Profiles I 


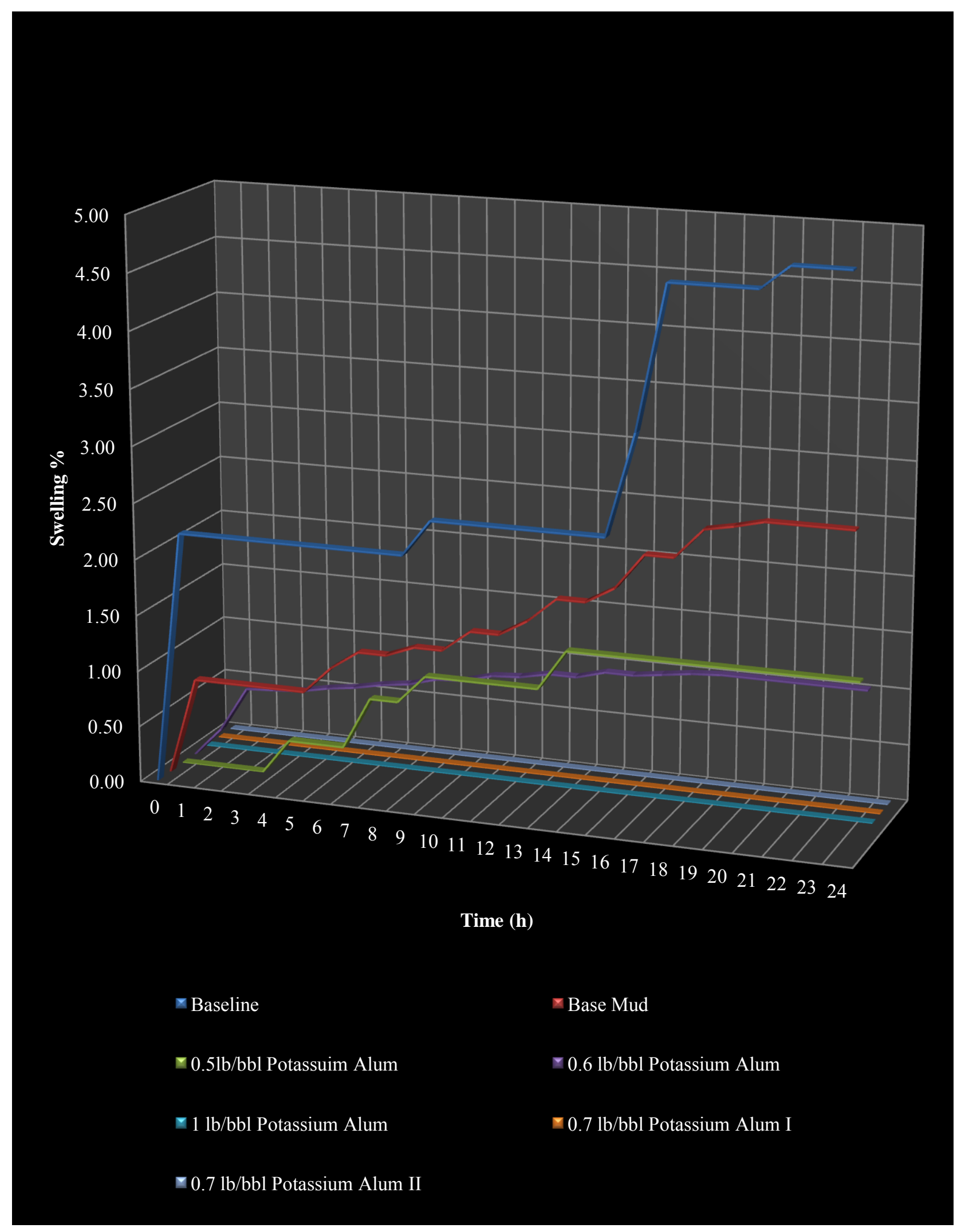

Figure 44: Comparison of Swelling Profiles II 
Figures 43 and 44 show the different swelling profiles of the Marcellus shale in the different muds. The water baseline had the highest and fastest swelling. In the fresh water case, primary swelling occurred immediately and reached $2.5 \%$ in the first hour of the test. The swelling was fairly stabilized for the next 15 hours. The secondary swelling increased to around $5 \%$ in less than two hours.

The base mud test showed a better performance, where it slowed the swelling process and lowered it by slightly over $2 \%$. This was due to the Cellex polymer which had inhabitation qualities. The primary swelling occurred immediately reaching $1 \%$ in the first hour and stabilized for 4 hours. Secondary swelling started after that and lasted for 16 hours; increasing swelling from $1 \%$ to $2.76 \%$.

The mud with the $0.5 \mathrm{lb} / \mathrm{bbl}$ potassium alum dramatically lowered the swelling. Even though the concentration of the inhibitor was small, it was able to lower the swelling to $1.40 \%$ in average compared to base mud. Interestingly, primary swelling started after 3 hours to reach around $0.4 \%$ and stabilized for two hours. Secondary swelling started after 6 hours from the start and continued for 8 hours and increased swelling by $1 \%$ only.

In the case of the $0.6 \mathrm{lb} / \mathrm{bbl}$ potassium alum, the swelling was lowered by $0.17 \%$ in average compared to the $0.5 \mathrm{lb} / \mathrm{bbl}$ potassium alum mud. However, the swelling profile was altered. Primary swelling started minutes after the test was started to reach approximately $0.8 \%$. Primary swelling duration was stretched to 18 hours before stabilizing. In this test there was no evidence of secondary swelling, and it seemed that there was only one stretched swelling stage. 
The $0.7 \mathrm{lb} / \mathrm{bbl}$ and $1 \mathrm{lb} / \mathrm{bbl}$ potassium alum muds completely stopped the shale from swelling. Nevertheless, it has been decided the $0.7 \mathrm{lb} / \mathrm{bbl}$ potassium alum mud to be the best performer after testing it on six samples with consistent results. 


\section{Mud Rheology Results and Discussion:}

Mud Rheology tests were performed on all mud samples. Overall, there was minor rheological alteration from base mud as the potassium alum was added. The mud density remained constant at $8.8 \mathrm{lb} / \mathrm{gal}$. For the base mud, $0.5 \mathrm{lb} / \mathrm{bbl}$ and $0.6 \mathrm{lb} / \mathrm{bbl}$ potassium alum muds the rheological properties were the same. For these samples, plastic viscosity was $8 \mathrm{cp}, 10 \mathrm{cp}$ for apparent viscosity, and $4 \mathrm{lb} / 100 \mathrm{ft}^{2}$ for yield point. On the other hand, rheological properties started to show small changes at $0.7 \mathrm{lb} / \mathrm{bbl}$ and $1 \mathrm{lb} / \mathrm{bbl}$ potassium alum mud samples. The 0.7 $\mathrm{lb} / \mathrm{bbl}$ potassium alum mud had a plastic viscosity of $9 \mathrm{cp}$, apparent viscosity of $10 \mathrm{cp}$ and yield point of $2 \mathrm{lb} / 100 \mathrm{ft}^{2}$. The $1 \mathrm{lb} / \mathrm{bbl}$ potassium alum mud had a plastic viscosity of $9 \mathrm{cp}$, apparent viscosity of $9.5 \mathrm{cp}$ and yield point of $1 \mathrm{lb} / 100 \mathrm{ft}^{2}$. The rheology test results for the $(0.5,0.6,0.7$ and 1) $1 \mathrm{~b} / \mathrm{bbl}$ muds are shown in Tables 15, 16, 17, 18 and 19 respectively.

\section{Base Mud:}

\begin{tabular}{|l|l|l|}
\hline Density & $\mathbf{8 . 8}$ & lb/gal \\
\hline
\end{tabular}

\begin{tabular}{|c|c|c|}
\hline$\phi_{600}$ & $\phi_{300}$ & $\phi_{3 \mathbf{G e l}}$ \\
\hline $\mathbf{c p}$ & $\mathbf{c p}$ & $\mathbf{c p}$ \\
\hline 20 & 12 & 5 \\
\hline
\end{tabular}

\begin{tabular}{|c|c|c|}
\hline$\mu_{\mathrm{p}}$ & 8 & $\mathrm{cp}$ \\
\hline$\mu_{\mathrm{a}}$ & 10 & $\mathrm{cp}$ \\
\hline $\mathbf{Y}_{\mathbf{b}}$ & 4 & $\mathrm{lb} / 100 \mathrm{ft}^{2}$ \\
\hline
\end{tabular}

Table 15: Base mud rheological properties 
Base Mud + 0.5 lb/bbl Potassium Alum:

\begin{tabular}{|l|c|c|}
\hline Density & 8.8 & lb/gal \\
\hline
\end{tabular}

\begin{tabular}{|c|c|c|}
\hline$\phi_{600}$ & $\phi_{300}$ & $\phi_{3 \mathbf{G e l}}$ \\
\hline $\mathbf{c p}$ & $\mathbf{c p}$ & $\mathbf{c p}$ \\
\hline 20 & 12 & 5 \\
\hline
\end{tabular}

\begin{tabular}{|c|c|c|}
\hline$\mu_{\mathrm{p}}$ & 8 & $\mathrm{cp}$ \\
\hline$\mu_{\mathrm{a}}$ & 10 & $\mathrm{cp}$ \\
\hline $\mathbf{Y}_{\mathbf{b}}$ & 4 & $1 \mathrm{~b} / 100 \mathrm{ft}^{2}$ \\
\hline
\end{tabular}

Table 16: $0.5 \mathrm{lb} / \mathrm{bbl}$ potassium alum mud rheological properties

Base Mud + 0.6 lb/bbl Potassium Alum:

\begin{tabular}{|l|l|l|}
\hline Density & 8.8 & lb/gal \\
\hline
\end{tabular}

\begin{tabular}{|c|c|c|}
\hline$\phi_{600}$ & $\phi_{300}$ & $\phi_{3 \mathbf{G e l}}$ \\
\hline $\mathbf{c p}$ & $\mathbf{c p}$ & $\mathbf{c p}$ \\
\hline 20 & 12 & 4 \\
\hline
\end{tabular}

\begin{tabular}{|c|c|c|}
\hline$\mu_{\mathrm{p}}$ & 8 & $\mathrm{cp}$ \\
\hline$\mu_{\mathrm{a}}$ & 10 & $\mathrm{cp}$ \\
\hline $\mathbf{Y}_{\mathbf{b}}$ & 4 & $\mathrm{lb} / 100 \mathrm{ft}^{2}$ \\
\hline
\end{tabular}

Table 17: $0.6 \mathrm{lb} / \mathrm{bbl}$ potassium alum mud rheological properties 
Base Mud + 0.7 lb/bbl Potassium Alum:

\begin{tabular}{|l|l|l|}
\hline Density & $\mathbf{8 . 8}$ & lb/gal \\
\hline
\end{tabular}

\begin{tabular}{|c|c|c|}
\hline$\phi_{600}$ & $\phi_{300}$ & $\phi_{3 \mathbf{G e l}}$ \\
\hline $\mathbf{c p}$ & $\mathbf{c p}$ & $\mathbf{c p}$ \\
\hline 20 & 11 & 4 \\
\hline
\end{tabular}

\begin{tabular}{|c|c|c|}
\hline$\mu_{\mathbf{p}}$ & 9 & $\mathrm{cp}$ \\
\hline$\mu_{\mathbf{a}}$ & 10 & $\mathrm{cp}$ \\
\hline $\mathbf{Y}_{\mathbf{b}}$ & 2 & $\mathrm{lb} / 100 \mathrm{ft}^{2}$ \\
\hline
\end{tabular}

Table 18: $0.7 \mathrm{lb} / \mathrm{bbl}$ potassium alum mud rheological properties

Base Mud + 1 lb/bbl Potassium Alum:

\begin{tabular}{|l|l|l|}
\hline Density & 8.8 & lb/gal \\
\hline
\end{tabular}

\begin{tabular}{|c|c|c|}
\hline$\phi_{600}$ & $\phi_{300}$ & $\phi_{3 \mathbf{G e l}}$ \\
\hline $\mathbf{c p}$ & $\mathbf{c p}$ & $\mathbf{c p}$ \\
\hline 19 & 10 & 3 \\
\hline
\end{tabular}

\begin{tabular}{|c|c|c|}
\hline$\mu_{\mathbf{p}}$ & 9 & $\mathrm{cp}$ \\
\hline$\mu_{\mathbf{a}}$ & 9.5 & $\mathrm{cp}$ \\
\hline $\mathbf{Y}_{\mathbf{b}}$ & 1 & $\mathrm{lb} / 100 \mathrm{ft}^{2}$ \\
\hline
\end{tabular}

Table 19: $1 \mathrm{lb} / \mathrm{bbl}$ potassium alum mud rheological properties 
Figures 45, 46 and 47 show the change in different rheological properties with respect to Potassium Alum concentration in $\mathrm{lb} / \mathrm{bbl}$.

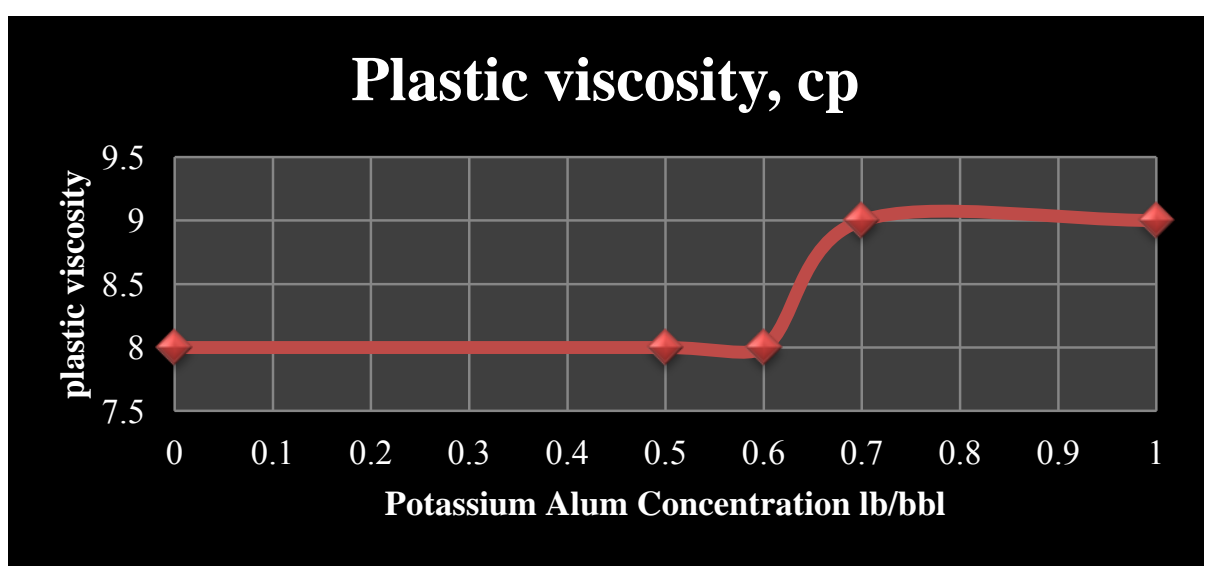

Figure 45: Plastic viscosity as a function of potassium Alum Concentration

\section{Apparent viscosity, cp}

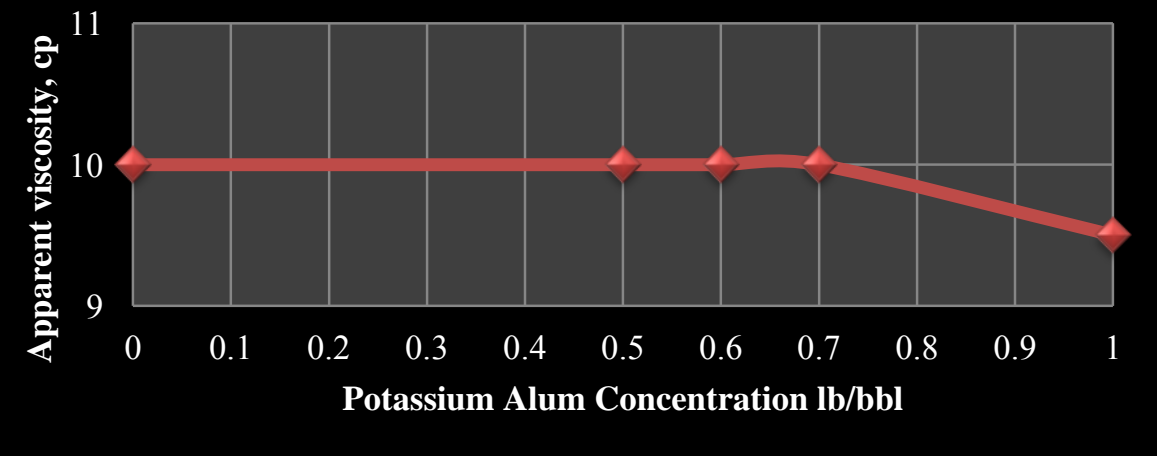

Figure 46: Apparent viscosity as a function of potassium Alum Concentration

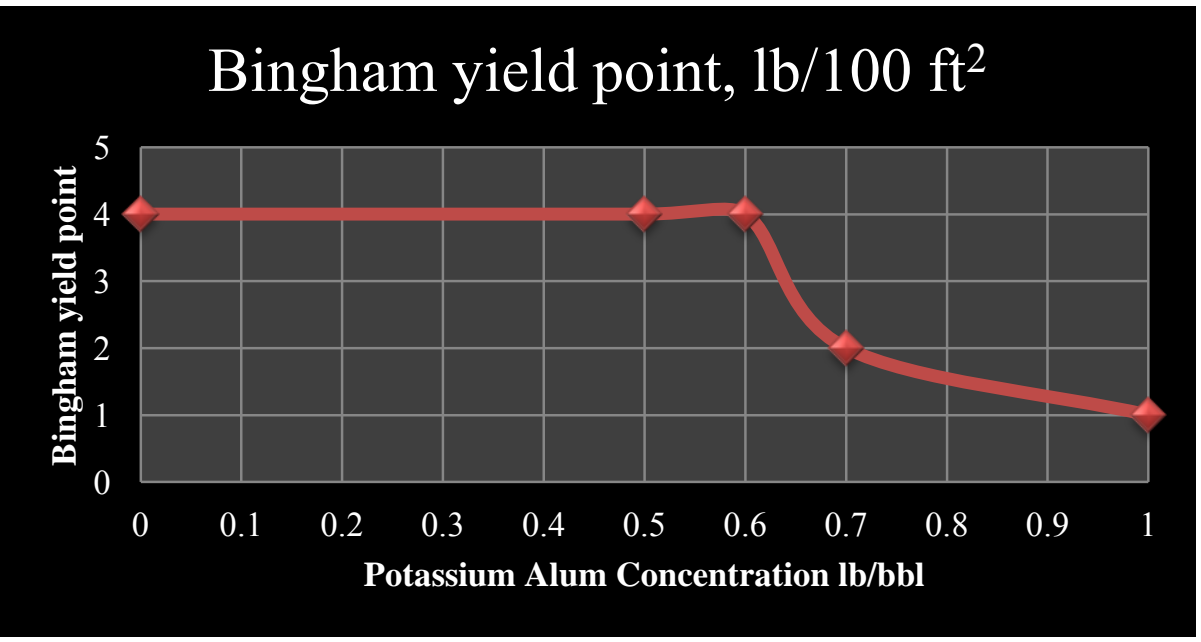

Figure 47: Bingham yield point as a function of potassium Alum Concentration 


\section{Filter Press Test results and Dissection:}

The results of this test on the mud samples had small deviations from the base mud sample. The base mud filtrate was $6.8 \mathrm{~mL}$ and yielded a $0.9 \mathrm{~mm}$ mud cake, while the $0.5 \mathrm{lb} / \mathrm{bbl}$ potassium alum sample had $6.7 \mathrm{~mL}$ filtrate and $1 \mathrm{~mm}$ mud cake. Also, the $0.6 \mathrm{lb} / \mathrm{bbl}$ potassium alum sample yielded $6.65 \mathrm{~mL}$ filtrate and $1.2 \mathrm{~mm}$ mud cake. The $0.7 \mathrm{lb} / \mathrm{bbl}$ potassium alum sample yield $6.9 \mathrm{~mL}$ filtrate and 1.3 mud cake. Finally, the $1 \mathrm{lb} / \mathrm{bbl}$ potassium alum sample had 7 $\mathrm{mL}$ filtrate and $1.7 \mathrm{~mm}$ mud cake. In general, all mud samples had relatively low filtration rates and yielded thin, low permeability mud cakes. Also, it is important to point that all mud cakes from this test were within the field recommended thickness of not exceeding $2 \mathrm{~mm}$. Table 20 show the filtrate volume in milliliter and mud cake thickness in millimeter results from the filter press tests different muds tested.

\begin{tabular}{|c|c|c|}
\hline Mud & Filtrate $\mathrm{mL}$ & Mud Cake $\mathrm{mm}$ \\
\hline Base & 6.8 & 0.9 \\
\hline Base $+0.5 \mathrm{lb} / \mathrm{bbl}$ Potassium Alum & 6.7 & 1 \\
\hline Base $+0.6 \mathrm{lb} / \mathrm{bbl}$ Potassium Alum & 6.65 & 1.2 \\
\hline Base $+0.7 \mathrm{lb} / \mathrm{bbl}$ Potassium Alum & 6.9 & 1.3 \\
\hline Base $+1 \mathrm{lb} / \mathrm{bbl}$ Potassium Alum & 7 & 1.7 \\
\hline
\end{tabular}

Table 20: Filter Press Test Results Summary 
Figuers 48 and 49 show the filter press results for muds tested with respect to Potassium Alum concentration in $\mathrm{lb} / \mathrm{bbl}$.

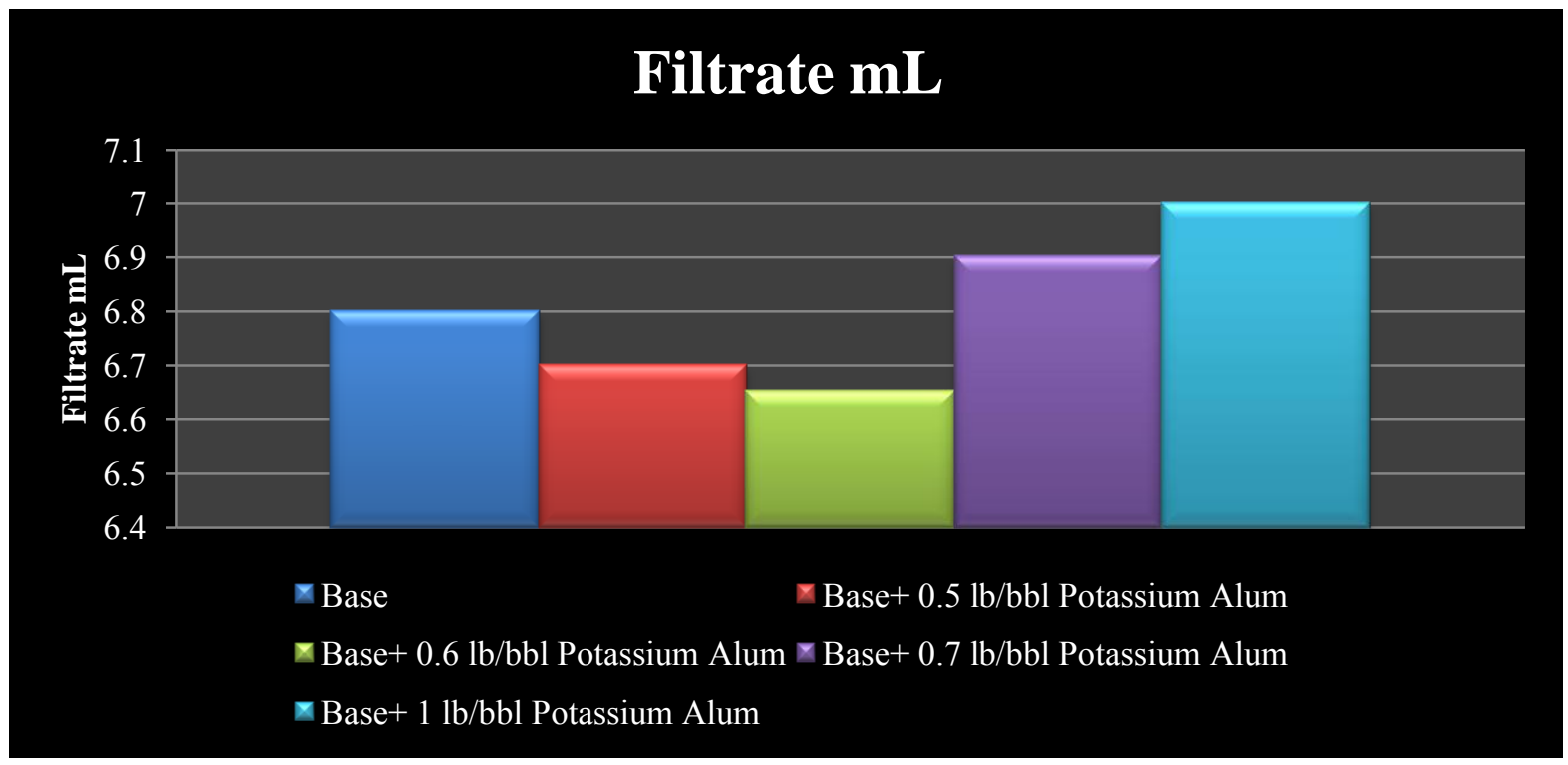

Figure 48: Filtrate volume at diffrent concentrations of potassuim alum

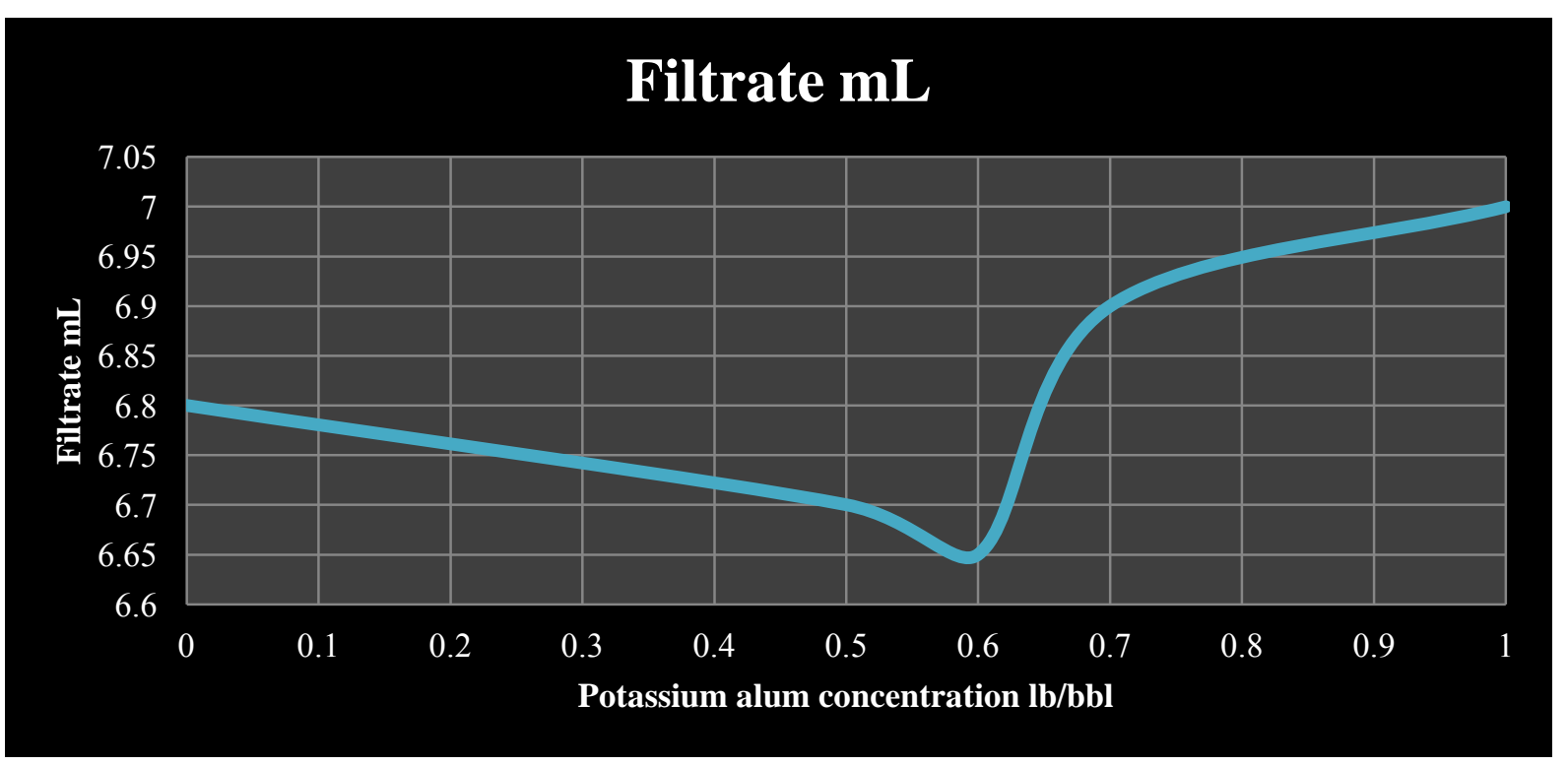

Figure 49: Filtrate volume with different concentrations of potassium alum 
Figuers 50 and 51 show the mud cake thickness results in millimeter from the filter press test for muds tested with respect to Potassium Alum concentration in lb/bbl.

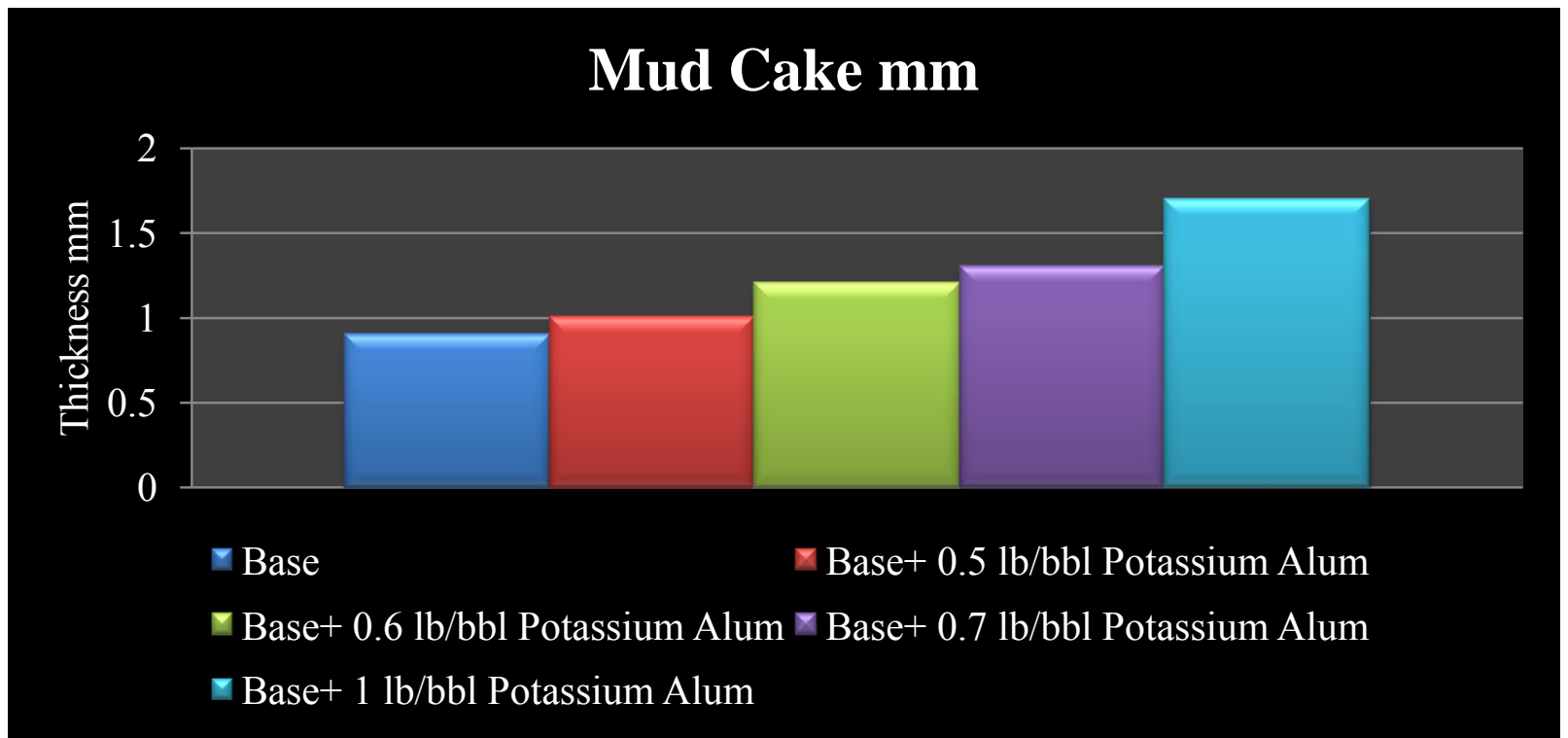

Figure 50: Mud cake thickness at different potassium alum concentrations

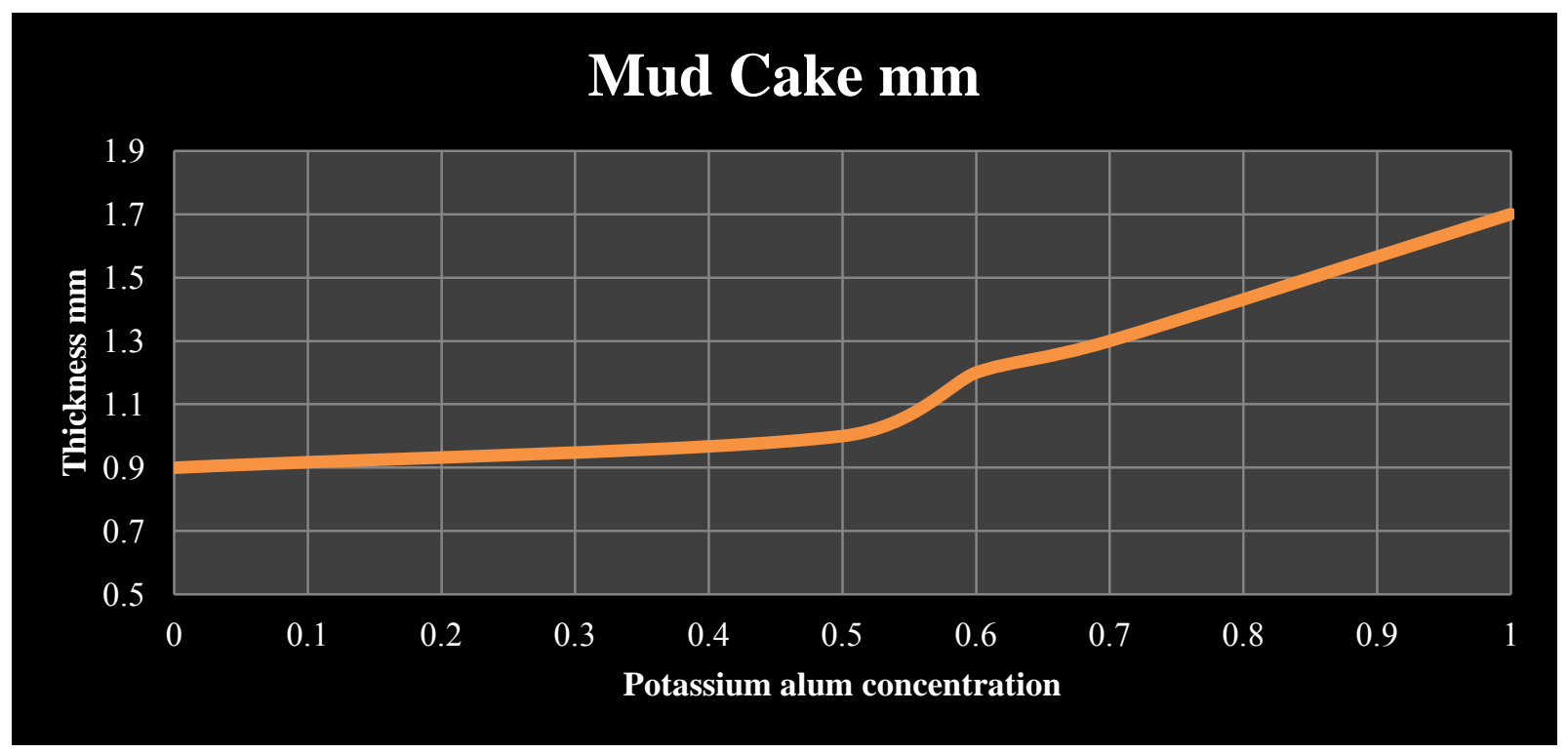

Figure 51: Mud cake thickness as a function of potassium alum concentration 


\section{Resistivity Test Results:}

Table 21 show the results summary for resistivity tests performed on the filtrate and mud cake yielded from the muds tested with different concentrations of Potassium Alum in lb/bbl.

\begin{tabular}{|c|c|c|}
\hline Mud & Filtrate Resistivity $\Omega$ & Mud Cake Resistivity $\Omega$ \\
\hline Base & 0.624 & 0.72 \\
\hline Base $+0.5 \mathrm{lb} / \mathrm{bbl}$ Potassium Alum & 0.582 & 0.706 \\
\hline Base $+0.6 \mathrm{lb} / \mathrm{bbl}$ Potassium Alum & 0.63 & 0.85 \\
\hline Base $+0.7 \mathrm{lb} / \mathrm{bbl}$ Potassium Alum & 0.613 & 0.702 \\
\hline Base $+1 \mathrm{lb} / \mathrm{bbl}$ Potassium Alum & 0.575 & 0.673 \\
\hline
\end{tabular}

Table 21: Filtrate \& mud cake resistivities results summary at diffrent conceintration of potassuim alum

Figures 52-55 show the results for resistivity tests performed on the filtrate and mud cake from the muds tested with different concentrations of Potassium Alum in lb/bbl.

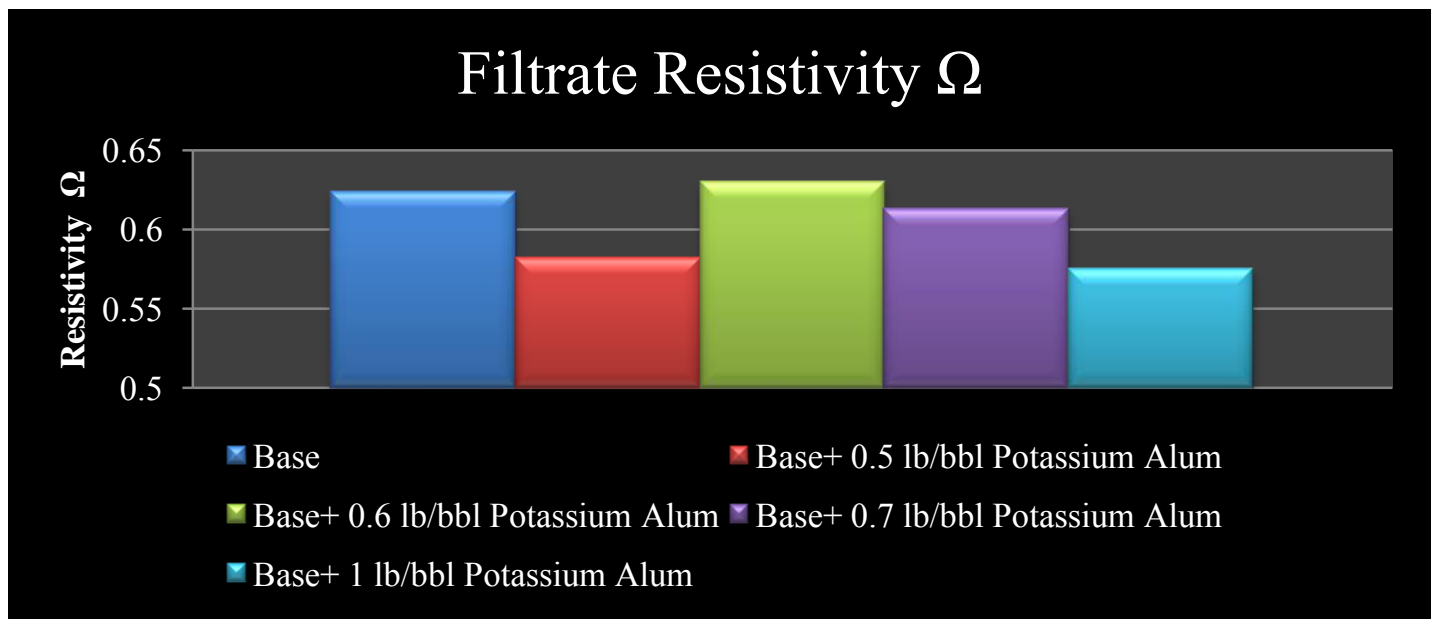

Figure 52: Filtrate resistivity at different potassium alum concentrations 


\section{Filtrate Resistivity $\Omega$}

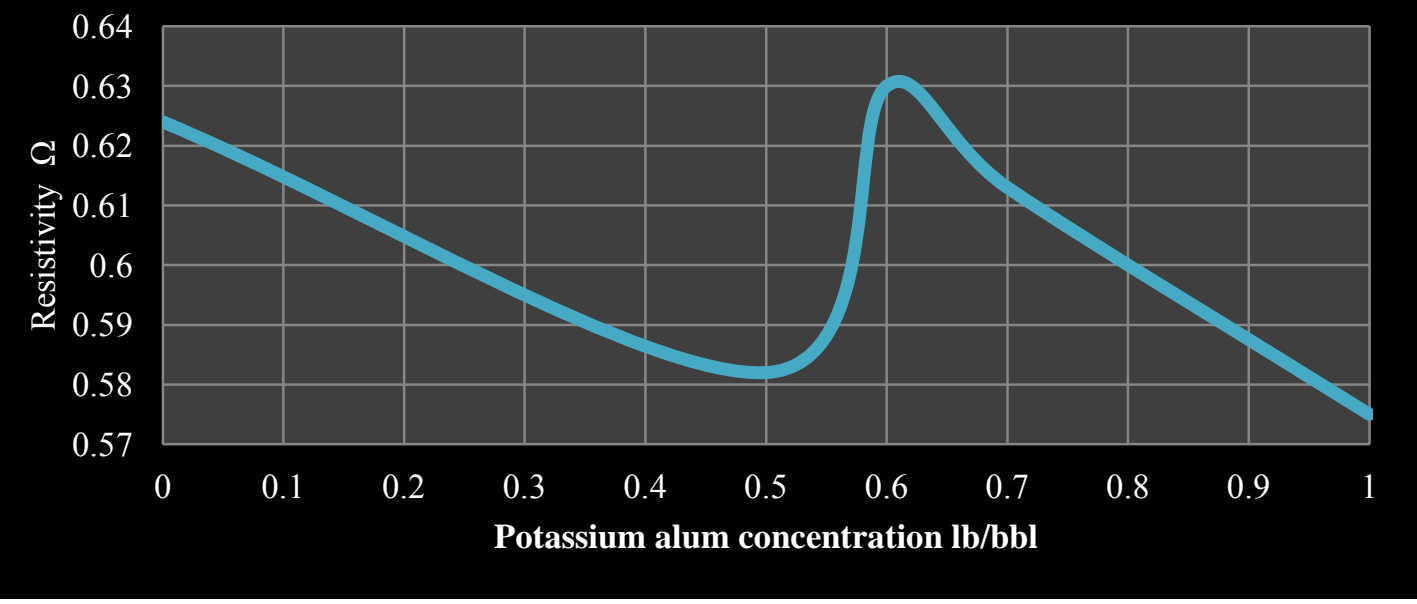

Figure 53: Filtrate resistivity as a function of potassium alum concentration

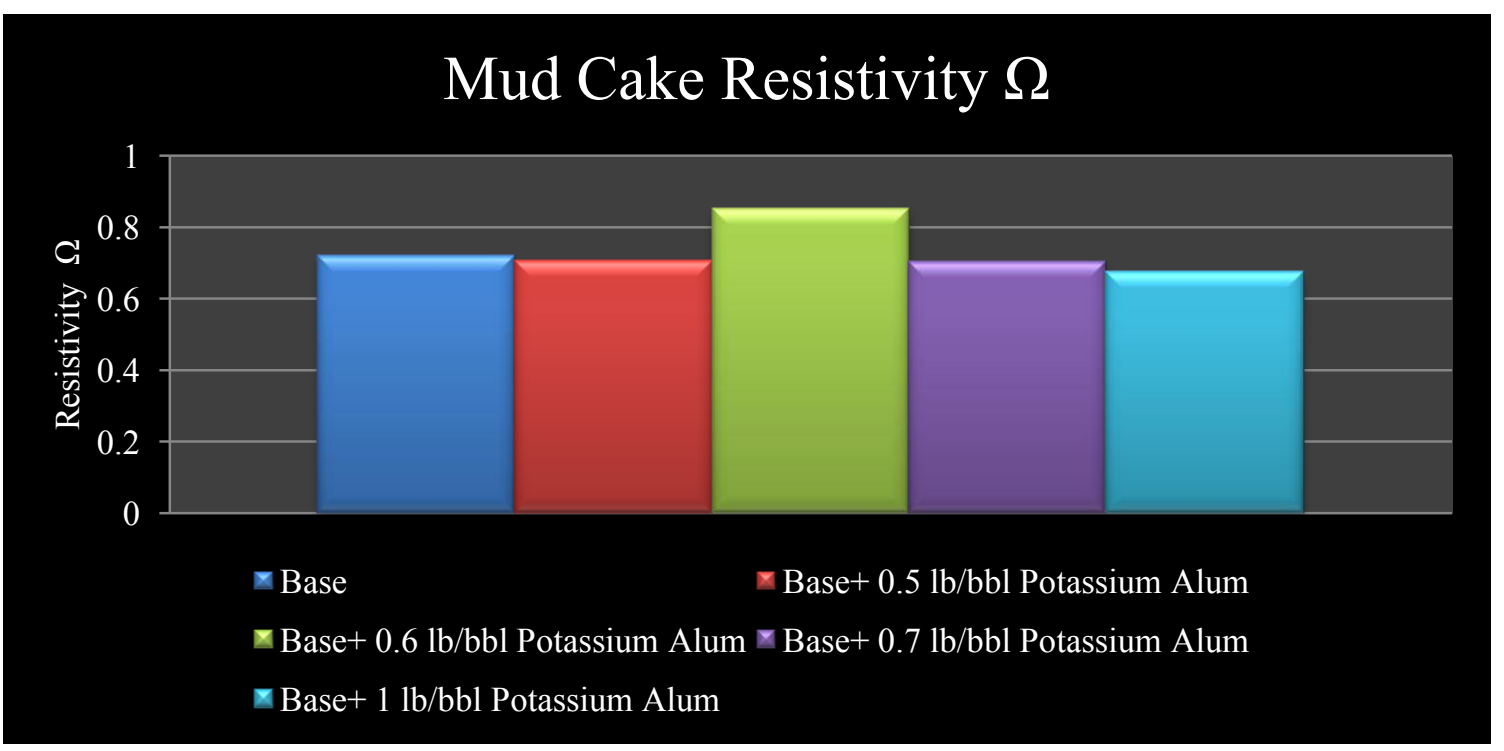

Figure 54: Mud cake resistivity at different potassium alum concentrations 


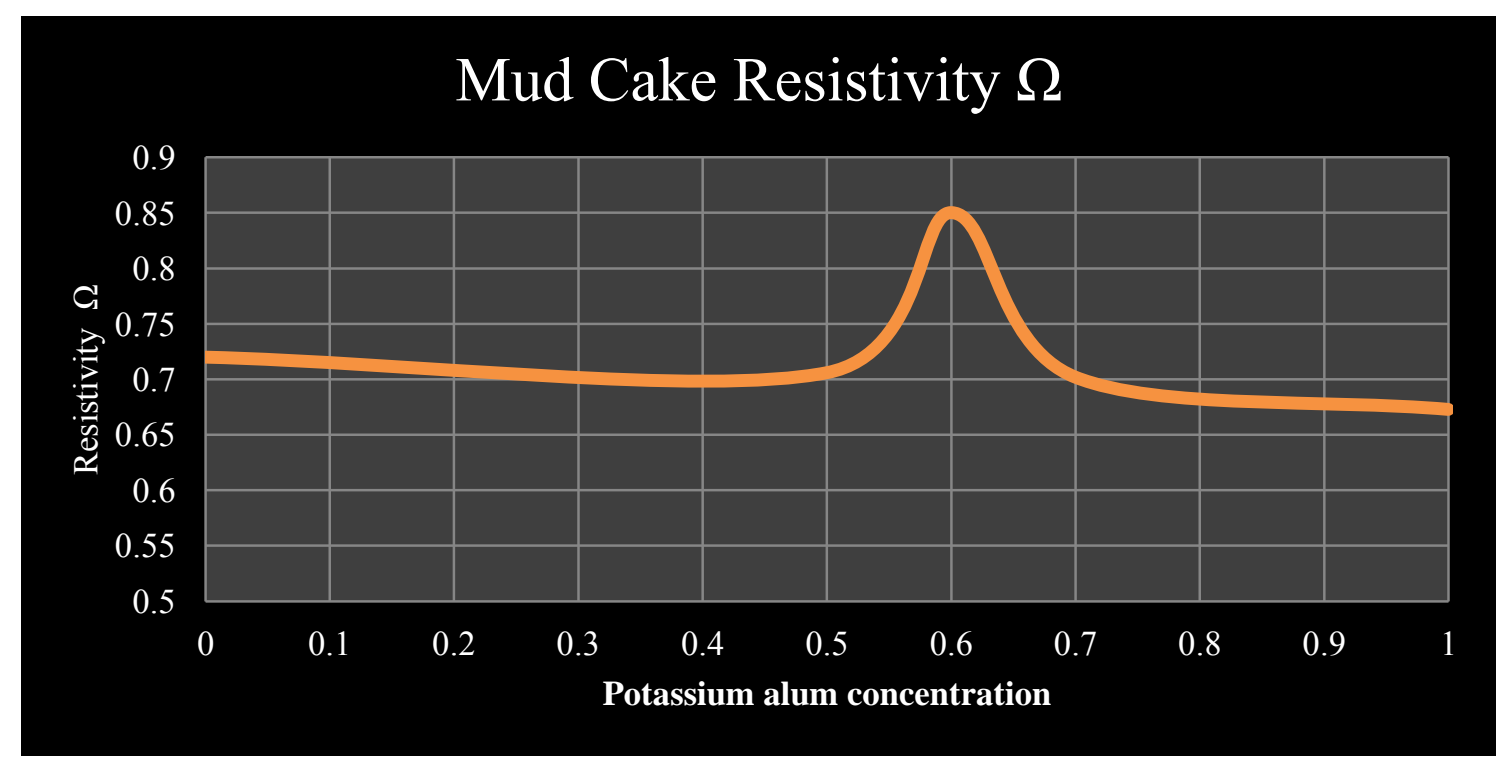

Figure 55: Mud cake resistivity as a function of potassium alum concentration 


\section{Filtrate as Drinking water test Results:}

For this test a water safety kit was used. The kit was based on the U.S. Environmental Protection Agency (EPA) guideline standards. The kit was designed to identify eight common contaminants, which are:

1- Bacteria

2- Lead

3- Pesticide

4- Nitrate

5- Nitrite

6- $\mathrm{pH}$

7- Hardness

8- Chlorine

This test was not intended to prove the drinkability of the mud filtrate, rather than how safe this mud is to be used and does not impose health or environmental hazards. The test was carefully conducted on the filtrate from the $0.7 \mathrm{lb} / \mathrm{bbl}$ potassium alum mud sample. The filtrate had to sit in a special bacteria test vial for 48 hours before confirming the result. The final result indicated no bacteria was detected. The rest of the tests were carried with test strips special for each one and all passed, except for the $\mathrm{pH}$ and hardness tests.

The $\mathrm{pH}$ level of the filtrate was around 10.8, which was part of the mud design to prevent the aluminum species from precipitating out the mud. Nonetheless, given that the mud has a low filtration rate; it is most likely that the filtrate will be diluted quickly if it somehow finds its way through a water bearing formation. The filtrate hardness was actually less than $85 \mathrm{ppm}$. When 
comparing the test strip to the color coded table from the test kit, it was slightly darker than the $50 \mathrm{ppm}$ label. However, a conservative approach was taken by adding the next higher value (120 ppm) on the reference table and taking the middle point. The hardness of the filtrate is caused by the mineral content in it, mainly the aluminum in this mud design. However, once the filtrate is diluted and $\mathrm{pH}$ value fall below 10 , the aluminum species will precipitate out of the water as aluminum hydroxide or aluminum minerals by reacting with ions in the water.

\begin{tabular}{|c|c|c|c|}
\hline Contaminant & Measurement & EPA Standard level & Result \\
\hline Bacteria & None & None & Passed \\
\hline Lead & None & $<15 \mathrm{ppb}$ & Passed \\
\hline Pesticide & None & $<3 \mathrm{ppb}$ & Passed \\
\hline Total Nitrate/Nitrite & $\mathbf{0}$ & $<\mathbf{1 0} \mathrm{ppm}$ & Passed \\
\hline Nitrite & $\mathbf{0}$ & $<1 \mathrm{ppm}$ & Passed \\
\hline pH & $\mathbf{1 0}$ & $\mathbf{6 . 5}$ to 8.5 & Failed \\
\hline Hardness & $\mathbf{8 5}$ & $\leq 50 \mathrm{ppm}$ & Failed \\
\hline Total Chlorine & $\mathbf{0}$ & $<4 \mathbf{p p m}$ & Passed \\
\hline
\end{tabular}

Table 22: Water safety kit results summary 


\section{Conclusion}

The aluminum chemistry proved to be very effective to control swelling of the Marcellus shale. The $0.7 \mathrm{lb} / \mathrm{bbl}$ potassium alum mud design completely suppress the swelling of shale. Also, the choice of using potassium alum as the aluminum hydroxide source was very successful. It had double inhabitation actions; precipitating chemistry and ion exchange as it provided potassium ions along with the aluminum. This eliminated the need to add potassium chloride $\mathrm{KCl}$ to enhance the performance of the mud, thus eliminating the chlorine byproduct. The shale swelling was reduced from approximately $5 \%$ to zero percent with the use of the $0.7 \mathrm{lb} / \mathrm{bbl}$ potassium alum in the mud.

Also, all mud components used were naturally occurring and biodegradable. The double inhibitive action of the additive resulted in using a low concentration. This added to the mud's handling/environmental safety and its economical feasibility. Although the mud is not to be used for human conception, the drinking water safety kit proved that the mud filtrate has no major impact as a water contaminant. The $\mathrm{pH}$ and hardness could be easily treated. However, drilling fluid disposal should comply with local, state, and federal regulations.

Finally, I recommend putting the mud through an aging cell to test how well the mud holds its rheological properties. Also, I recommend performing swelling test at elevated temperature and pressure levels to examine their effect on the inhabitation quality of the mud at near down-hole conditions. 


\section{Works Cited}

Arvind, Patel. "Design and Development of Quaternary Amine Compounds: Shale Inhibition With Improved Environmental Profile." SPE International Symposium on Oilfield Chemistry. Woodlands: Society of Petroleum Engineers,SPE 121737, 2009. 1-9.

Arvind, Patel, Emanuel Stamatakis, Steve Young, and Jim Friedheim. "Advances in Inhibitive WaterBased Drilling Fluids - Can They Replace Oil-Based Muds?" SPE International Symposium on Oilfield Chemistry. Houston: Society of Petroleum Engineers,SPE 106476, 2007. 1-8.

Bourgoyne Jr., A, M Chenevert, K Millhelm, and F.S Young Jr. Applied Drilling Engineering. Eighth Edition . Vol. 2. Richardson, Texas: Society of Petroleum Engineers, ISBN 1-55563-001-4, 2001.

Boyce, Matthew L, and Timothy R Carr. Lithostratigraphy and Petrophysics of the Devonian Marcellus Interval in. Department of Geology\& Geography, Morgantown: West Virginia University, 2009.

D, Clark, and Benaissa Saddok. "Aluminum Chemistry Provides Increased Shale Stability With." SPE Asia Pacific Oil \& Gas Conference \& Exhibition. Singapore: Society of Petroleum Engineers,SPE25321, 1993. 85-97.

Gallade Chemical. 2012. http://www.galladechem.com/ (accessed February 2, 2012).

Geology.com. http://geology.com/rocks/shale.shtml (accessed 5 10, 2011).

Halliburton. U.S. Shale Gas, An Unconventional Resource. Unconventional Challenges. 72008. http://www.halliburton.com/public/solutions/contents/Shale/related_docs/H063771.pdf (accessed 5 13, 2011).

Halliday, W.S., T.A. Jones, and Byron Sketcher. "Polyglycol and Aluminum Chemistry Drilling Fluid Helps Operator Reach Project Goals." SPE/IADC Drilling Conference. Amsterdam: Society of Petroleum Engineers/International Association of Drilling Contractors,SPE/IADC 25702, 1993. 1-9.

Hong, Wang. "Rethinking of Shale Swelling Based on Interesting Test Results." The 44th US Rock Mechanics Symposium. Salt Lake City: American Rock Mechanics Association,ARMA 10-172, 2010. 2 5 .

Lal, Manohar. "Shale Stability: Drilling Fluid Interaction and Shale Strength." Latin American and Caribbean Petroleum Engineering Conference. Caracas: Society of Petroleum Engineers,SPE 54356, 1999. 1-10.

M., Ramirez, Clapper D., and Kenny P. "Drilling-Fluid Design for Challenging Wells in the Andean Mountain Region." SPE Annual Technical Conference and. San Antonio: Society of Petroleum Engineers,SPE 102206, 2006. 1-11.

M., Ramirez, Clapper D., Sanchez G., and Luna E. "Aluminum-Based HPWBM Successfully Replaces Oil-Based Mud to Drill Exploratory Wells in an Environmentally Sensitive Area." SPE Latin American and Caribbean Petroleum Engineering Conference. Rio de Janeiro: Society of Petroleum Engineers,SPE 94437, 2005. 1-12. 
Projecting the Economic Impact of Marcellus Shale Gas Development in West Virginia. Government Report, National Energy Technology Laboratory, 2010.

Sabine, Goldberg, H Forster, and C Godfrey. "Molybdenum Adsorption on Oxides, Clay Minerals, and Soils." Soil Science Society of America Journal 60, no. 2 (1996): 425-432.

Schlumberger. 2012. http://slb.com/.

Stowe, Cal, William Halliday, Tao Xiang, Dennis Clapper, Keith Morton, and Shawna Hartman.

"Laboratory Pore Pressure Transmission Testing of Shale." National Drilling Conference, "Drilling Technology- The Next 100 years". Houston,Texas: American Association of Drilling Engineers,AADE 01-NC-HO-44, 2001. 1-10.

Wells, Michael, Tim Marvel, Chad Beuershausen, and Hughes Christensen. "Bit Balling Mitigation in PDC Bit Design." IADC/SPE Asia Pacific Drilling Technology Conference and Exhibition. Jakarta: Society of Petroleum Engineers/International Association of Drilling Contractors,IADC/SPE 114673, 2008. 1-25.

West Virginia Geological and Economic Survey.

http://www.wvgs.wvnet.edu/www/datastat/devshales.htm (accessed December 15, 2011). 


\section{Appendix}

1- Water Baseline:

\section{Swelling Experiments Log}

\begin{tabular}{|l|l|}
\hline Sample \# & 21 \\
\hline Initial Weight $(\mathbf{g})$ & 26.6 \\
\hline Final Weight $(\mathbf{g})$ & 26.3 \\
\hline Initial Height $\mathbf{( m m )}$ & 3.427 \\
\hline Swelling Height $\mathbf{( m m )}$ & 0.169 \\
\hline Swelling \% & 4.93 \\
\hline Remarks & Tested with dynamic swelling meter \\
\hline
\end{tabular}

\begin{tabular}{|l|l|}
\hline Sample \# & 17 \\
\hline Initial Weight $\mathbf{( g )}$ & 25.6 \\
\hline Final Weight $(\mathbf{g})$ & 25.4 \\
\hline Initial Height $\mathbf{( m m )}$ & 3.302 \\
\hline Swelling Height $\mathbf{( m m )}$ & 0.161 \\
\hline Swelling \% & 4.88 \\
\hline Remarks & Tested on dial indicator \\
\hline
\end{tabular}

\begin{tabular}{|l|l|}
\hline Sample \# & 19 \\
\hline Initial Weight $\mathbf{( g )}$ & 23.8 \\
\hline Final Weight $\mathbf{( g )}$ & 23.7 \\
\hline Initial Height $\mathbf{( m m )}$ & 3.074 \\
\hline Swelling Height $\mathbf{( m m )}$ & 0.156 \\
\hline Swelling \% & 5.07 \\
\hline Remarks & Tested on dial indicator \\
\hline
\end{tabular}

\section{Results Summary:}

\begin{tabular}{|c|c|c|c|}
\hline Sample \# & H Initial $(\mathrm{mm})$ & Swelling Height $(\mathrm{mm})$ & Swelling \% \\
\hline 17 & 3.302 & 0.161 & 4.88 \\
\hline 19 & 3.074 & 0.156 & 5.07 \\
\hline 21 & 3.427 & 0.169 & 4.93 \\
\hline Average & & & 4.96 \\
\hline
\end{tabular}




\section{2- Base Mud:}

\begin{tabular}{|l|l|}
\hline Sample \# & 14 \\
\hline Initial Weight $\mathbf{( g )}$ & 32.3 \\
\hline Final Weight $(\mathbf{g})$ & 32.0 \\
\hline Initial Height $(\mathbf{m m})$ & 4.162 \\
\hline Swelling Height $\mathbf{( m m )}$ & 0.115 \\
\hline Swelling \% & 2.76 \\
\hline Remarks & Tested with dynamic swelling meter \\
\hline
\end{tabular}

\begin{tabular}{|l|l|}
\hline Sample \# & 18 \\
\hline Initial Weight $\mathbf{( g )}$ & 31.7 \\
\hline Final Weight $\mathbf{( g )}$ & 31.5 \\
\hline Initial Height $(\mathbf{m m})$ & 4.084 \\
\hline Swelling Height $(\mathbf{m m})$ & 0.120 \\
\hline Swelling \% & 2.94 \\
\hline Remarks & Tested on dial indicator \\
\hline
\end{tabular}

\begin{tabular}{|l|l|}
\hline Sample \# & 12 \\
\hline Initial Weight $\mathbf{( g )}$ & 28.0 \\
\hline Final Weight $(\mathbf{g})$ & 27.7 \\
\hline Initial Height $(\mathbf{m m})$ & 3.607 \\
\hline Swelling Height $\mathbf{( m m )}$ & 0.109 \\
\hline Swelling \% & 3.02 \\
\hline Remarks & Tested on dial indicator \\
\hline
\end{tabular}

\section{Results Summary:}

\begin{tabular}{|c|c|c|c|}
\hline Sample \# & H Initial $(\mathrm{mm})$ & Swelling Height(mm) & Swelling \% \\
\hline 18 & 4.084 & 0.120 & 2.94 \\
\hline 12 & 3.607 & 0.109 & 3.02 \\
\hline 14 & 4.162 & 0.115 & 2.75 \\
\hline Average & & & 2.90 \\
\hline
\end{tabular}




\section{3- $1 \mathrm{lb} / \mathrm{bbl}$ Potassium Alum Concentration :}

\begin{tabular}{|l|l|}
\hline Sample \# & 28 \\
\hline Initial Weight $\mathbf{( g )}$ & 47.5 \\
\hline Final Weight $(\mathbf{g})$ & 47.1 \\
\hline Initial Height $(\mathbf{m m})$ & 6.107 \\
\hline Swelling Height $(\mathbf{m m})$ & 0 \\
\hline Swelling \% & 0 \\
\hline Remarks & Tested with dynamic swelling meter \\
\hline
\end{tabular}

\begin{tabular}{|l|l|}
\hline Sample \# & 23 \\
\hline Initial Weight $(\mathbf{g})$ & 44.0 \\
\hline Final Weight $(\mathbf{g})$ & 43.6 \\
\hline Initial Height $(\mathbf{m m})$ & 5.660 \\
\hline Swelling Height $(\mathbf{m m})$ & 0 \\
\hline Swelling \% & 0 \\
\hline Remarks & Tested on dial indicator \\
\hline
\end{tabular}

\begin{tabular}{|l|l|}
\hline Sample \# & 11 \\
\hline Initial Weight $(\mathbf{g})$ & 44.0 \\
\hline Final Weight $(\mathbf{g})$ & 43.6 \\
\hline Initial Height $(\mathbf{m m})$ & 7.128 \\
\hline Swelling Height $(\mathbf{m m})$ & 0 \\
\hline Swelling \% & 0 \\
\hline Remarks & Tested on dial indicator \\
\hline
\end{tabular}

\section{Results Summary:}

\begin{tabular}{|c|c|c|c|}
\hline Sample \# & H Initial $(\mathrm{mm})$ & Swelling Height $(\mathrm{mm})$ & Swelling \% \\
\hline 28 & 6.107 & 0 & 0 \\
\hline 23 & 5.660 & 0 & 0 \\
\hline 11 & 7.128 & 0 & 0 \\
\hline Average & & & 0 \\
\hline
\end{tabular}




\section{4- $0.5 \mathrm{lb} / \mathrm{bbl}$ Potassium Alum Concentration:}

\begin{tabular}{|l|l|}
\hline Sample \# & 16 \\
\hline Initial Weight $(\mathbf{g})$ & 45.2 \\
\hline Final Weight $(\mathbf{g})$ & 44.7 \\
\hline Initial Height $(\mathbf{m m})$ & 6.652 \\
\hline Swelling Height $(\mathbf{m m})$ & 0.093 \\
\hline Swelling \% & 1.40 \\
\hline Remarks & Tested with dynamic swelling meter \\
\hline
\end{tabular}

\begin{tabular}{|l|l|}
\hline Sample \# & 15 \\
\hline Initial Weight $\mathbf{( g )}$ & 43.3 \\
\hline Final Weight $(\mathbf{g})$ & 42.9 \\
\hline Initial Height $(\mathbf{m m})$ & 5.574 \\
\hline Swelling Height $\mathbf{( m m )}$ & 0.079 \\
\hline Swelling \% & 1.42 \\
\hline Remarks & Tested on dial indicator \\
\hline
\end{tabular}

\begin{tabular}{|l|l|}
\hline Sample \# & 13 \\
\hline Initial Weight $(\mathbf{g})$ & 49.6 \\
\hline Final Weight $(\mathbf{g})$ & 49.4 \\
\hline Initial Height $(\mathbf{m m})$ & 6.990 \\
\hline Swelling Height $(\mathbf{m m})$ & 0.098 \\
\hline Swelling \% & 1.40 \\
\hline Remarks & Tested on dial indicator \\
\hline
\end{tabular}

\section{Results Summary:}

\begin{tabular}{|c|c|c|c|}
\hline Sample \# & H Initial $(\mathrm{mm})$ & Swelling Height $(\mathrm{mm})$ & Swelling \% \\
\hline 15 & 5.574 & 0.079 & 1.42 \\
\hline 13 & 6.99 & 0.098 & 1.40 \\
\hline 16 & 6.652 & 0.093 & 1.40 \\
\hline Average & & & 1.41 \\
\hline
\end{tabular}


5- 0.6 lb/bbl Potassium Alum Concentration:

\begin{tabular}{|l|l|}
\hline Sample \# & 8 \\
\hline Initial Weight $(\mathbf{g})$ & 36.6 \\
\hline Final Weight $(\mathbf{g})$ & 36.3 \\
\hline Initial Height $(\mathbf{m m})$ & 5.764 \\
\hline Swelling Height $(\mathbf{m m})$ & 0.072 \\
\hline Swelling \% & 1.25 \\
\hline Remarks & Tested with dynamic swelling meter \\
\hline
\end{tabular}

\begin{tabular}{|l|l|}
\hline Sample \# & 5 \\
\hline Initial Weight $\mathbf{( g )}$ & 36.4 \\
\hline Final Weight $(\mathbf{g})$ & 36.1 \\
\hline Initial Height $(\mathbf{m m})$ & 5.190 \\
\hline Swelling Height $(\mathbf{m m})$ & 0.064 \\
\hline Swelling \% & 1.23 \\
\hline Remarks & Tested on dial indicator \\
\hline
\end{tabular}

\begin{tabular}{|l|l|}
\hline Sample \# & 3 \\
\hline Initial Weight $(\mathbf{g})$ & 34.1 \\
\hline Final Weight $(\mathbf{g})$ & 33.7 \\
\hline Initial Height $(\mathbf{m m})$ & 5.619 \\
\hline Swelling Height $(\mathbf{m m})$ & 0.070 \\
\hline Swelling \% & 1.25 \\
\hline Remarks & Tested on dial indicator \\
\hline
\end{tabular}

\section{Results Summary:}

\begin{tabular}{|c|c|c|c|}
\hline Sample \# & H Initial $(\mathrm{mm})$ & Swelling Height(mm) & Swelling \% \\
\hline 3 & 5.619 & ------ & ----- \\
\hline 5 & 5.190 & 0.064 & 1.23 \\
\hline 8 & 5.764 & 0.072 & 1.25 \\
\hline Average & & & 1.24 \\
\hline
\end{tabular}




\section{6- $0.7 \mathrm{lb} / \mathrm{bbl}$ Potassium Alum Concentration:}

\begin{tabular}{|l|l|}
\hline Sample \# & 10 \\
\hline Initial Weight $\mathbf{( g )}$ & 31.5 \\
\hline Final Weight $\mathbf{( g )}$ & 31.2 \\
\hline Initial Height $(\mathbf{m m})$ & 5.024 \\
\hline Swelling Height $\mathbf{( m m )}$ & 0 \\
\hline Swelling \% & 0 \\
\hline Remarks & Tested with dynamic swelling meter \\
\hline
\end{tabular}

\begin{tabular}{|l|l|}
\hline Sample \# & 2 \\
\hline Initial Weight $(\mathbf{g})$ & 31.1 \\
\hline Final Weight $(\mathbf{g})$ & 30.7 \\
\hline Initial Height $(\mathbf{m m})$ & 4.815 \\
\hline Swelling Height $\mathbf{( m m )}$ & 0 \\
\hline Swelling \% & 0 \\
\hline Remarks & Tested on dial indicator \\
\hline
\end{tabular}

\begin{tabular}{|l|l|}
\hline Sample \# & 6 \\
\hline Initial Weight $(\mathbf{g})$ & 32.3 \\
\hline Final Weight $(\mathbf{g})$ & 31.9 \\
\hline Initial Height $(\mathbf{m m})$ & 4.307 \\
\hline Swelling Height $(\mathbf{m m})$ & 0 \\
\hline Swelling \% & 0 \\
\hline Remarks & Tested on dial indicator \\
\hline
\end{tabular}


7- 0.7 lb/bbl Potassium Alum Concentration: (Redo/ Confirmation)

\begin{tabular}{|l|l|}
\hline Sample \# & 7 \\
\hline Initial Weight $(\mathbf{g})$ & 47.1 \\
\hline Final Weight $(\mathbf{g})$ & 46.7 \\
\hline Initial Height $(\mathbf{m m})$ & 7.005 \\
\hline Swelling Height $(\mathbf{m m})$ & 0 \\
\hline Swelling \% & 0 \\
\hline Remarks & Tested with dynamic swelling meter \\
\hline
\end{tabular}

\begin{tabular}{|l|l|}
\hline Sample \# & 5 \\
\hline Initial Weight $(\mathbf{g})$ & 27.7 \\
\hline Final Weight $(\mathbf{g})$ & 27.4 \\
\hline Initial Height $(\mathbf{m m})$ & 4.930 \\
\hline Swelling Height $(\mathbf{m m})$ & 0 \\
\hline Swelling \% & 0 \\
\hline Remarks & Tested on dial indicator \\
\hline
\end{tabular}

\begin{tabular}{|l|l|}
\hline Sample \# & 1 \\
\hline Initial Weight $(\mathbf{g})$ & 26.5 \\
\hline Final Weight $(\mathbf{g})$ & 26.2 \\
\hline Initial Height $(\mathbf{m m})$ & 3.705 \\
\hline Swelling Height $(\mathbf{m m})$ & 0 \\
\hline Swelling \% & 0 \\
\hline Remarks & Tested on dial indicator \\
\hline
\end{tabular}

\section{Results Summary:}

\begin{tabular}{|c|c|c|c|}
\hline Sample \# & H Initial $(\mathrm{mm})$ & Swelling Height $(\mathrm{mm})$ & Swelling \% \\
\hline 2 & 4.815 & 0 & 0.00 \\
\hline 6 & 4.307 & 0 & 0.00 \\
\hline 10 & 5.024 & 0 & 0.00 \\
\hline 5 & 4.930 & 0 & 0.00 \\
\hline 1 & 3.705 & 0.001 & 0.03 \\
\hline 7 & 7.005 & 0 & 0.00 \\
\hline Average & & & 0.01 \\
\hline
\end{tabular}

